\title{
Georgia: Request for Stand-By Arrangement-Staff Report; Staff Supplement; Press Release on the Executive Board Discussion; and Statement by the Executive Director for Georgia
}

In the context of the request for Stand-By Arrangement, the following documents have been released and are included in this package:

- $\quad$ The staff report for the Request for Stand-By Arrangement, prepared by a staff team of the IMF, following discussions that ended on September 4, 2008, with the officials of Georgia on economic developments and policies. Based on information available at the time of these discussions, the staff report was completed on September 10, 2008. The views expressed in the staff report are those of the staff team and do not necessarily reflect the views of the Executive Board of the IMF.

- A staff supplement of September 12, 2008, on the assessment of the risks to the Fund and the Fund's liquidity position.

- A Press Release summarizing the views of the Executive Board as expressed during its September 15, 2008 discussion of the staff report that completed the review.

- $\quad$ A statement by the Executive Director for Georgia.

The documents listed below have been or will be separately released.

Letter of Intent sent to the IMF by the authorities of Georgia*

Memorandum of Economic and Financial Policies by the authorities of Georgia*

Technical Memorandum of Understanding*

*Also included in Staff Report

The policy of publication of staff reports and other documents allows for the deletion of market-sensitive information.

Copies of this report are available to the public from

International Monetary Fund • Publication Services

$70019^{\text {th }}$ Street, N.W. $\bullet$ Washington, D.C. 20431

Telephone: (202) 623-7430 • Telefax: (202) 623-7201

E-mail: publications@imf.org •Internet: http://www.imf.org

Price: $\$ 18.00$ a copy

\section{International Monetary Fund Washington, D.C.}



INTERNATIONAL MONETARY FUND

GEORGIA

Request for Stand-By Arrangement

Prepared by the Middle East and Central Asia Department

(In consultation with other departments)

Approved by David Owen and Adnan Mazarei

September 10, 2008

Context. In the wake of the early August armed conflict, investor confidence has weakened. As a result, Georgia is experiencing substantial pressures in its capital account that have created a balance of payments financing need.

Request for Stand-By Arrangement. The authorities have requested an 18-month arrangement for SDR 477.1 million (317 percent of quota), equivalent to about $\$ 750$ million, which would constitute exceptional access. SDR 161.7 million (\$250 million) would become available upon Board approval.

The program. Fund support to the government's macroeconomic policies is intended to provide the needed financing to rebuild gross international reserves, and to help restore investor confidence. The authorities intend to (i) strengthen the underlying fiscal stance to limit the financing need and refocus spending priorities on reconstruction; (ii) adjust the monetary stance to protect international reserves and allow a return to a flexible exchange rate regime as confidence is restored; and (iii) develop plans to mitigate potential banking system vulnerabilities.

Team. A.L. Coronel (Head), C. Dieterich, J. Koeda, K. Ariyapruchya, I. Yu (all MCD), P. Lohmus (MCM), and A. Sadikov (SPR). D. Owen (MCD) joined the mission for its last week, and A. Bakker (OED) and E. Gardner (Senior Resident Representative in Lebanon) joined the concluding discussions.

Exchange rate regime. Managed float with no predetermined path for the exchange rate. A temporary de facto exchange rate peg to the U.S. dollar was introduced in the wake of the early August armed conflict.

Statistics. Economic data are adequate for surveillance and program monitoring. Georgia participates in the GDDS. 


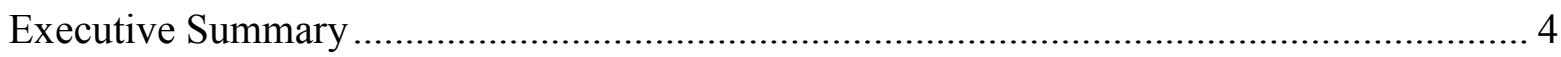

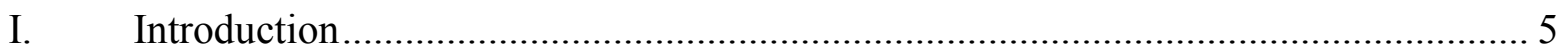

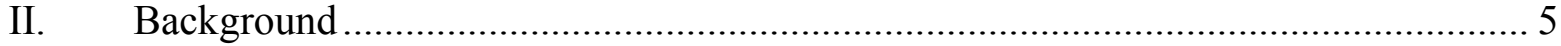

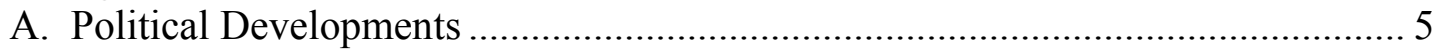

B. Recent Economic Developments ............................................................... 6

C. Macroeconomic and Financial Sector Policies Before the Conflict ..................... 8

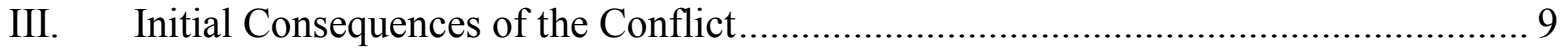

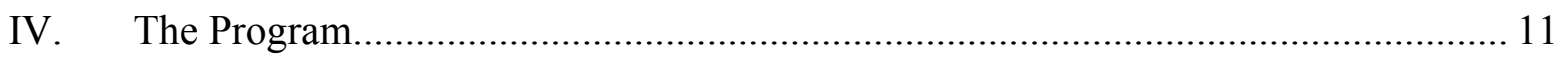

A. Macroeconomic Framework ...................................................................... 12

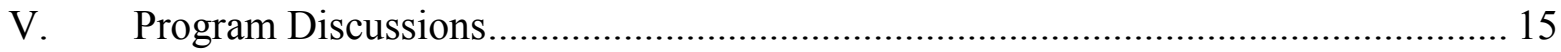

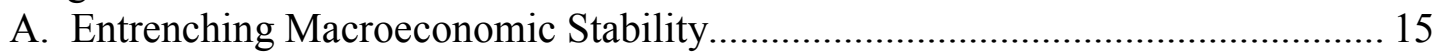

B. Strengthening Financial Sector Soundness .............................................. 18

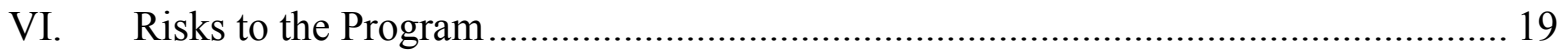

VII. Program Access, Monitoring, and Capacity to Repay the Fund............................ 19

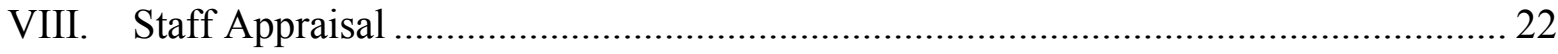

\section{Figures}

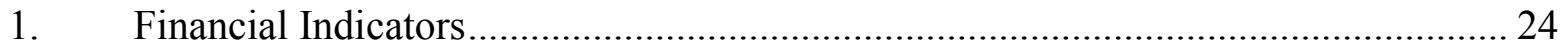

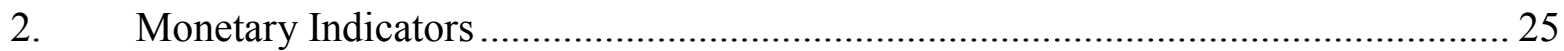

Tables

1. Selected Macroeconomic Indicators, 2006-12 ............................................. 26

2. Annual Consolidated Government Operations, 2006-10 …............................... 27

3. Quarterly Consolidated Government Operations, 2008-09................................. 28

4. Summary Balance of Payments, 2006-12 .......................................................... 29

5. Accounts of the National Bank of Georgia, 2006-09.......................................... 30

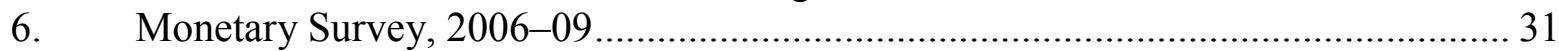

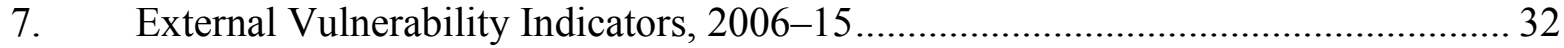

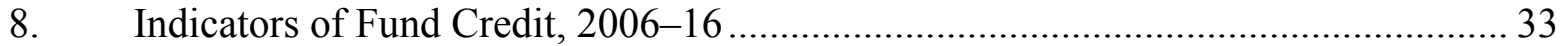

9. External Financing Requirements and Sources, 2006-12 ................................. 34

10. Prudential Indicators of Commercial Banks, 2004-08 ........................................... 35

11. Review and Disbursements Under the 18-Month SBA ....................................... 36 


\section{Text Tables}

1. Prudential Indicators of Commercial Banks, 2004-08 ....................................... 9

2. Balance of Payments Indicators, 2008-09 ...................................................... 12

3. Macroeconomic Framework, 2007-10 ................................................................ 14

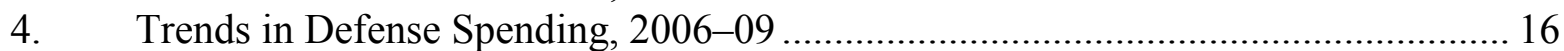

\section{Boxes}

1. Actions to Address the Temporary Liquidity Needs ............................................ 11

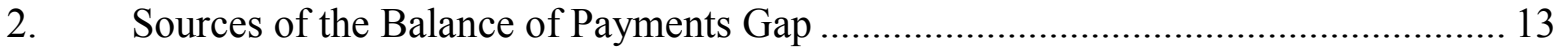

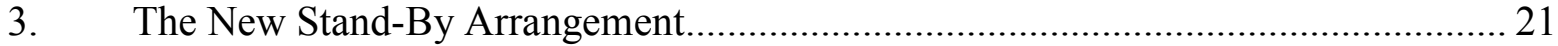

\section{Attachments}

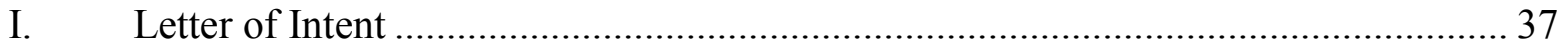

II. Memorandum of Economic and Financial Policies for 2008 and 2009.................. 39

III. Technical Memorandum of Understanding ...................................................... 51

IV. External and Public Sector Debt Sustainability Analysis ..................................... 56

V. Exceptional Access for Request for a Stand-By Arrangement .............................. 67 


\section{EXECUTIVE SUMMARY}

In the wake of the early August armed conflict, the Georgian authorities have requested an 18-month, \$750 million Stand-By Arrangement (SBA), which constitutes exceptional access. Pressures on the capital account stemming from the loss of investor confidence since the start of the conflict have been reflected in a large decline in international reserves, a fall in bank deposits, and increased Eurobond spreads. The program is designed to make significant resources available upon approval in order to replenish international reserves and help restore investor confidence, with the aim of sustaining private capital inflows that have been critical to Georgia's growth performance in recent years. In addition to the Fund resources, Georgia will likely receive financial assistance from multilateral and bilateral donors and creditors in support of the reconstruction effort.

The authorities' program aims to limit the deterioration in the external accounts by containing the fiscal deficit, maintaining a cautious monetary stance, and further strengthening the financial sector. The program targets only a moderate adjustment in the current account in 2008-09, recognizing that a sharp tightening of fiscal and monetary policies at this stage would carry excessive costs. The immediate focus will be on avoiding liquidity disruptions and accepting higher fiscal spending on reconstruction, while retaining the main medium-term direction of economic policies in place before the conflict.

On fiscal policy, the plan is to reduce current expenditures in order to free resources for relief and reconstruction. Currently available financing for 2008-09 comprises the proceeds of the $\$ 500$ million Eurobond issued this year, and privatization receipts. Concessional loans and grants to be provided by multilateral and bilateral partners - in an amount that is still uncertain - are expected to finance further reconstruction needs, and will be accommodated within the fiscal targets.

Monetary policy has to tackle the dilemma of providing sufficient liquidity to the banking system while stabilizing the exchange rate and avoiding an excessive loss of international reserves. The program supports the authorities' short-term policy of avoiding excessive volatility in the exchange rate but envisages a return to a flexible exchange rate regime as soon as market conditions allow.

The banking system has been resilient to the current pressures, but there are concerns about liquidity and asset quality. To address these challenges, the supervisory authorities are working with banks on plans to assess vulnerabilities and mitigate risks. The program envisages actions to strengthen the framework for providing liquidity, build up the capacity of the Financial Supervision Agency (FSA), strengthen its independence, and enhance cooperation between the central bank and the FSA.

The risks to the program are considerable. Escalation of regional or domestic tensions or a less benign international economic environment could result in a greater-than-anticipated deterioration of investor confidence. A weakening of bank asset quality and reduced access to foreign borrowing are also risks. If these scenarios emerge, the authorities have indicated that they are prepared to act quickly by strengthening policies and mobilizing financing, and they will consult closely with the Fund, including in the context of quarterly program reviews. 


\section{INTRODUCTION}

1. The Georgian authorities have requested support for their economic program in the form of a front-loaded 18-month $\mathbf{\$ 7 5 0}$ million Stand-By Arrangement (SBA). Given that Georgia's quota is SDR 150.3 million (about \$236 million), this would constitute exceptional access since it would exceed limits of 100 percent of quota annually and 300 percent of quota (net of scheduled repurchases) cumulatively. The request is based on a balance of payments financing need reflecting the likely impact of the early August armed conflict on investor confidence. Pressures on the capital account stemming from the jolt to market confidence have been reflected in a large loss of international reserves, a fall in bank deposits, increased Eurobond spreads, and strong signs of a decline in net private inflows. Access under the program is designed to build up gross reserves to a level that, along with the macroeconomic policies described in the attached Memorandum of Economic and Financial Policies (MEFP), would help restore confidence. Phasing is designed to make significant resources available upon approval because of the urgent need to replenish the reserves lost during and after the conflict. The authorities intend to draw on the initial purchase. Decisions on the other purchases will be subject to developments in market conditions.

2. While Georgia is a PRGF-eligible country, its per-capita income has risen rapidly in recent years. Per-capita income reached over $\$ 2,300$ in 2007, and Georgia has recently become an IDA/IBRD-blend country. Fund credit outstanding stood at SDR 138.9 million (92 percent of quota) as of end-August 2008. The last Article IV consultation was concluded in March 2006. Due to the May elections and the August conflict, the next Article IV consultation is now scheduled at the time of the second program review.

\section{BACKGROUND}

\section{A. Political Developments}

3. Tensions remain high after the early-August armed conflict. A ceasefire was agreed in mid-August but uncertainty remains, and the longstanding frictions regarding the two breakaway regions of South Ossetia and Abkhazia have increased.

4. The domestic political context is also challenging. Following an eruption of public discontent in late 2007, President Saakashvili was reelected in January 2008 and his political movement won a 60 percent majority in the May parliamentary elections. The president's popular support rose after the recent events, but tensions remain as the opposition has been demanding higher participation in political life and greater attention to social issues. 


\section{B. Recent Economic Developments}

5. The economy depends heavily on large foreign inflows. Impressive economic reforms and the government's aggressive privatization program have spurred substantial foreign direct investment. ${ }^{1}$ Portfolio investment was given a jumpstart when the largest private bank placed bonds in international capital markets last year. Despite the political events of late 2007 and election uncertainty, private inflows reached a record level of \$2.2 billion (22 percent of GDP) in 2007 and \$1.5 billion in the first half of 2008 .
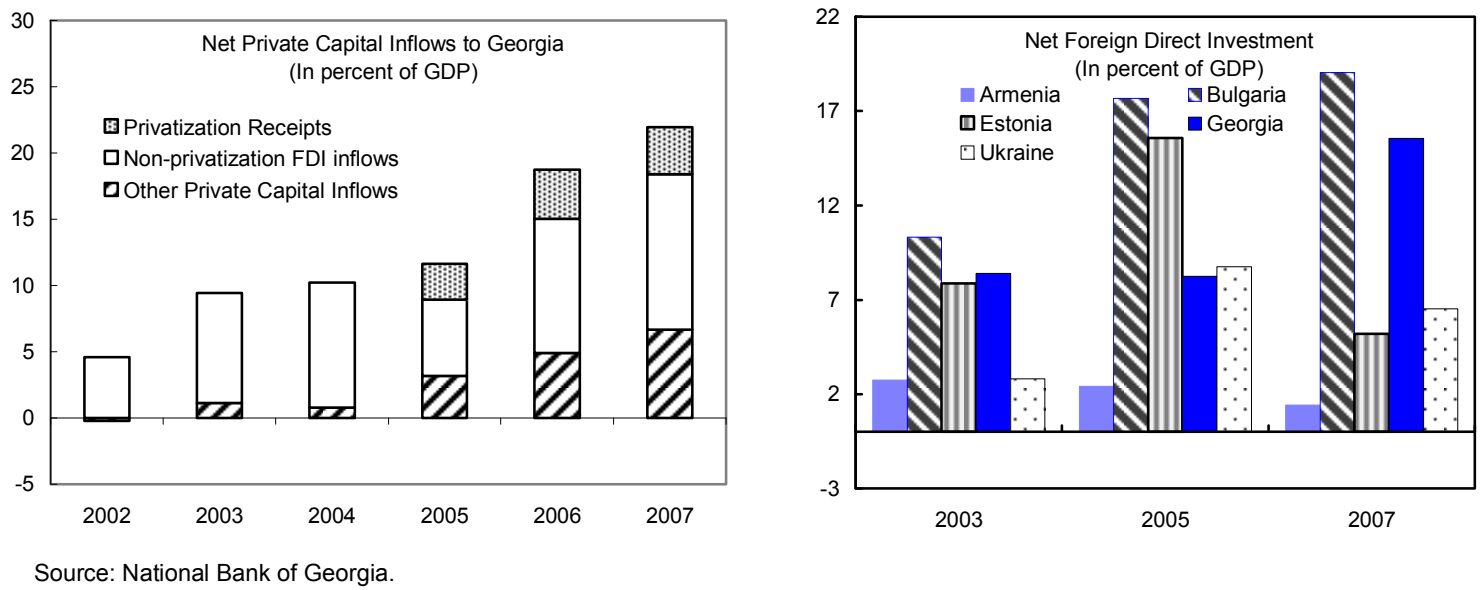

6. Driven by foreign inflows, economic growth reached double digits amid rising inflation and a widening current account deficit.

- $\quad$ Real GDP grew by $12 \frac{1}{2}$ percent in 2007 exceeding the impressive 2003-07 average of around 10 percent — and by $9 \frac{1}{4}$ percent (year-on-year) in the first quarter of 2008. Growth has been broad based, with manufacturing, trade services, construction, and financial intermediation as the leading drivers.

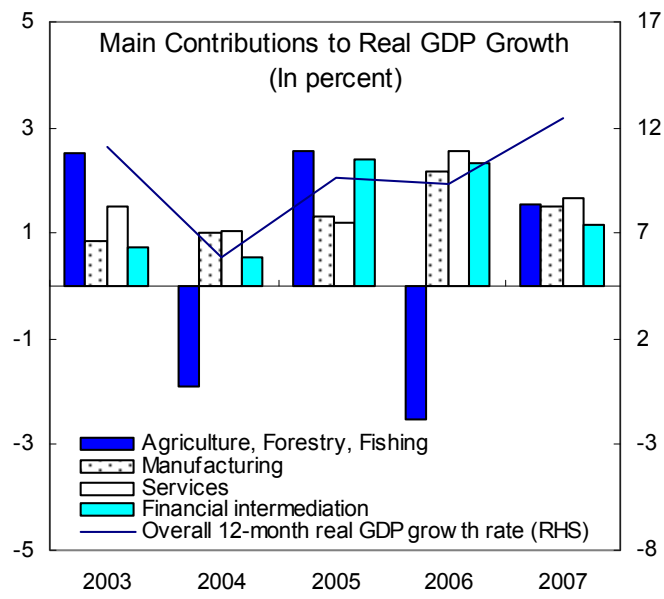

- Inflation - which the authorities have been struggling to contain since 2006peaked at 12\% percent in March 2008 before slowing to 93/4 percent in July. Strong

\footnotetext{
${ }^{1}$ In the World Bank's Doing Business survey, Georgia has moved up by 95 positions since 2004, reaching position 18 out of 178 countries in 2008.
} 
domestic demand and the global rise in food and energy prices, which account for more than half of the consumption basket, drove the increase.

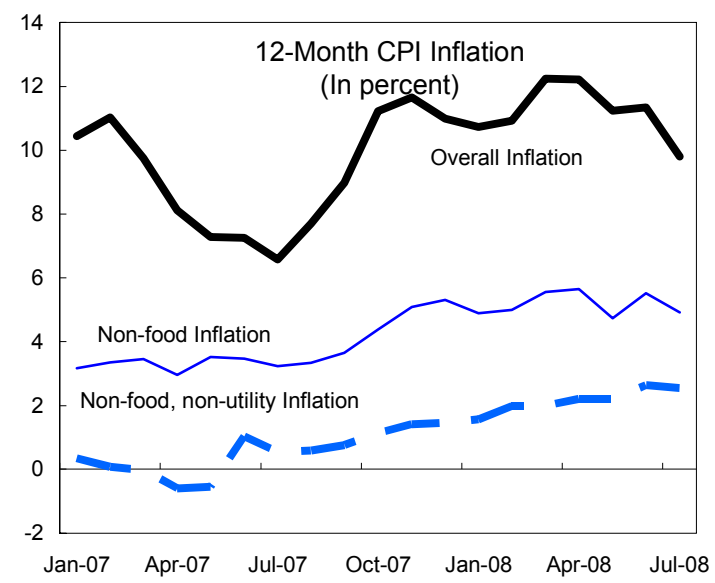

- The external current account deficit reached 20 percent of GDP in 2007 and rose to about 26 percent in the first half of 2008 reflecting strong domestic demand, FDI-related imports, and higher commodity import prices, only partly offset by growing remittances and the recovery of export growth from the effect of Russian trade restrictions. ${ }^{2}$ Private capital inflows fully financed the deficit, and gross international reserves increased by $\$ 104$ million to $\$ 1.5$ billion (2.5 months

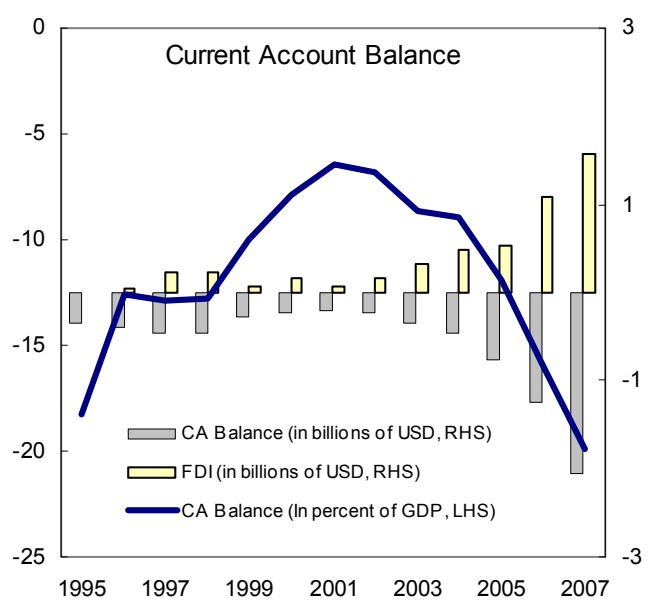
of imports) by end-July 2008.

- $\quad$ The REER continued to appreciate during 2007 and the first semester of 2008 due to high domestic inflation and accelerated nominal appreciation in response to massive capital inflows. The lari appreciated by 13 percent vis-à-vis the U.S. dollar during the first seven months of the year.

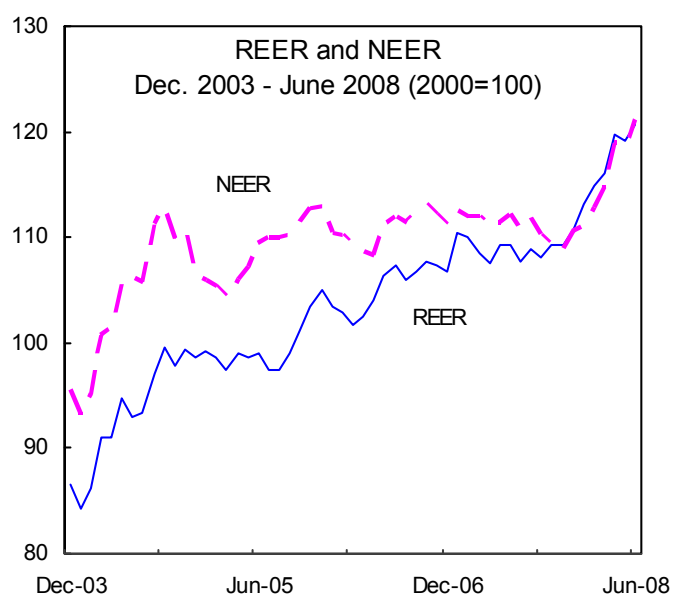

\footnotetext{
${ }^{2}$ Since 2006, Russia has banned all Georgian exports.
} 


\section{Macroeconomic and Financial Sector Policies Before the Conflict}

7. The authorities modified their policy framework in early 2008 in an attempt to entrench sound macroeconomic policies amid political opposition. Some of the provisions contained in that framework, for example, the legal commitment to permanent fiscal surpluses (counting privatization earnings as fiscal revenues) may prove too rigid in the face of the recent shock. Others, such as the declaration of price stability as the main monetary policy objective (in preparation for a formal inflation-targeting framework in 2009), the strengthening of central bank accountability, and the creation of a FSA as an independent legal entity will contribute to sound macroeconomic management in the face of this temporary shock.

8. Political events contributed to rapid increases in budgetary spending. Successive budget supplements - reflecting fast spending prior to the elections in January and May 2008, and higher defense outlays - eroded the fiscal stance relative to the original budgets. The increased expenditure was largely matched by strong revenue performance and high privatization proceeds, and the fiscal deficit reached 41/2 percent of GDP in 2007 and 6 percent in the first half of 2008.
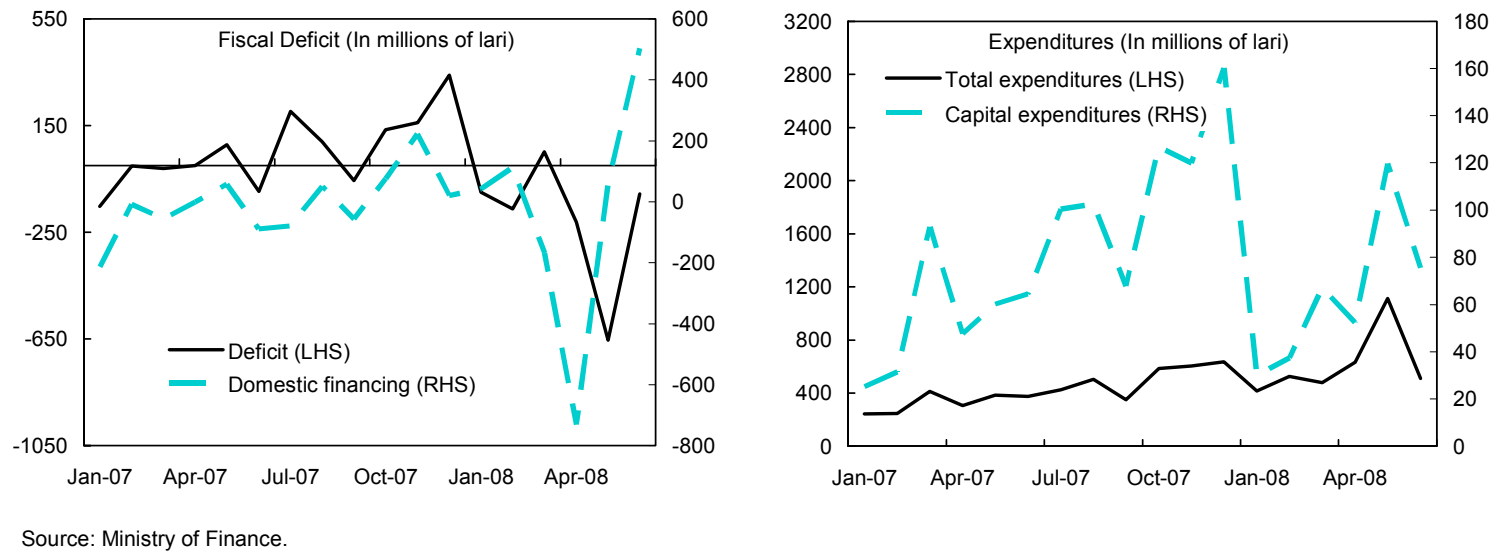

9. Monetary policy focused on resisting inflationary pressures. The NBG increased interest rates aggressively (by 6 percentage points on 90-day CDs up to July) and allowed significant lari appreciation. These policies reduced the annual growth of broad money and credit to 27 percent and 48 percent, respectively in July, compared with 50 percent and 70 percent at end-2007. Dollarization remains high (60 percent of deposits and 65 percent of lending).

10. Financial soundness indicators remained generally adequate, but tight liquidity has exposed vulnerabilities in the banking sector. With slower deposit growth, banks have increasingly relied on foreign borrowing despite rising borrowing costs, and their exposure to indirect credit risk from lending in foreign currency (as well as to the potential deterioration of the property market) is significant. While bank profitability remains robust, and aggregate 
capital adequacy is well above the regulatory minimum, falling liquidity ratios and rising nonperforming loans (NPLs) signal increasing vulnerabilities. Liquidity was squeezed on two occasions earlier this year, forcing NBG liquidity injections and FSA intervention in two small banks. The increasing level of NPLs may still not fully reflect the impact of the credit boom on loan quality.

Text Table 1. Georgia: Prudential Indicators of Commercial Banks, 2004-08

\begin{tabular}{lrrrrrr}
\hline & 2004 & 2005 & 2006 & \multirow{2}{*}{2007} & \multicolumn{2}{c}{2008} \\
\cline { 5 - 7 } & & & & Mar. & Jun. \\
\hline Capital adequacy ratio (in percent) & & & & & & \\
Nonperforming loans (in percent of total loans) & 6.2 & 3.8 & 2.5 & 2.6 & 3.0 & 3.4 \\
Loans in foreign exchange (in percent of total loans) & 86.7 & 76.2 & 73.8 & 68.6 & 65.9 & 64.9 \\
Net open foreign exchange position 1/ & 7.4 & 7.5 & 3.7 & 5.0 & 3.5 & 1.5 \\
Liquidity ratio (in percent) & 45.0 & 33.3 & 41.5 & 37.2 & 36.8 & 33.3 \\
& & & & & & \\
\hline
\end{tabular}

Source: National Bank of Georgia.

1/ Percent of Total Regulatory Capital.

\section{The issuance of Georgia's first international sovereign bond represented a} change in the authorities' debt management strategy. Previously, public borrowing had been almost exclusively on concessional terms. The $\$ 500$ million five-year Eurobond was issued in April 2008, ${ }^{3}$ and its proceeds were intended to bolster the country's liquid resources for dealing with future shocks. About three-fourths of the proceeds were invested in newly created sovereign wealth funds, and the remainder (\$130 million) was deposited in a government account in the NBG. Notwithstanding this operation, the public external debt-toGDP ratio fell significantly from 50 percent of GDP in 2000 to 171/2 percent in mid-2008, reflecting strong economic growth and real lari appreciation.

\section{Initial CONSEQuences of The CONFlict}

12. With the assistance of development partners, the government is assessing the physical damage resulting from the conflict. The assessment has not been finalized, but damage to civilian infrastructure is tentatively estimated by the authorities at about $\$ 1$ billion. There is a need to resettle the internally displaced persons, address interruptions in transportation, electricity and gas supplies, rebuild infrastructure, and remove bottlenecks that impede private sector activities.

\section{The erosion of confidence that emerged during and immediately after the} conflict was substantial. The authorities focused on preventing disruptions to the payments system. Aided by temporary measures to avoid further market uneasiness (see Box 1), they

\footnotetext{
${ }^{3}$ At a spread of 474 basis points over comparable U.S. Treasury securities (a yield of around 7.5 percent), the cost of this issue was comparable to that of similarly rated sovereign issues (those rated B+by S\&P).
} 
met all liquidity needs, which were volatile and directly related to the evolving developments.

- Gross international reserves fell significantly reflecting a sharp slowdown in net foreign inflows. Reserves declined by $\$ 330$ million (23 percent) between August 6 (the day before the conflict) and August 31, reflecting NBG intervention in the foreign exchange market (sales of $\$ 187$ million in contrast with net purchases of $\$ 360$ million in January-July), the decision to temporarily waive reserve requirements on foreign exchange deposits, and government imports. The pace of reserve losses has slowed in early September.

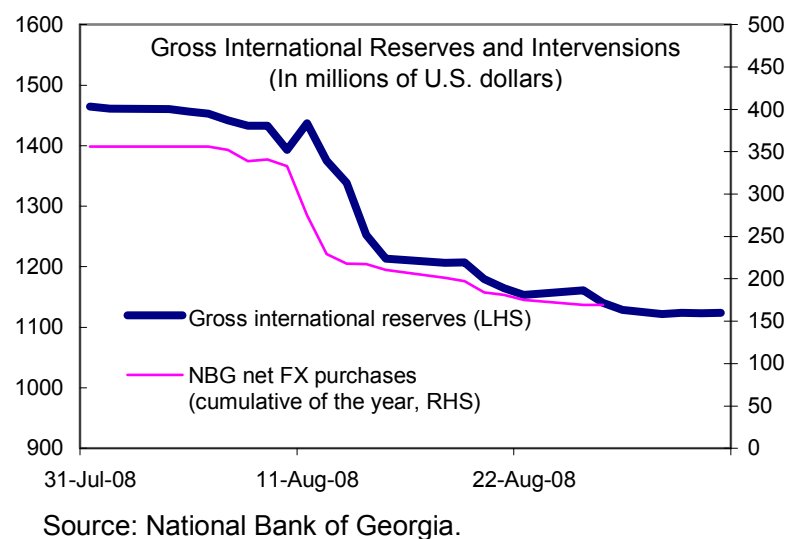

There were significant withdrawals of bank deposits. Bank deposits declined by about 400 million lari (14 percent). Both corporations and households contributed to the withdrawal, and the demand for foreign exchange increased, while interbank lending declined substantially. Small deposit inflows occurred in the third week of August but outflows have continued into early September and the situation has not yet fully stabilized.

\section{- Country risk rose sharply. Georgia's} sovereign bond spread over comparable U.S. treasuries reached its peak at 775 basis points during the conflict, 240 points higher than the pre-conflict level, and has remained at over 700 basis points. Standard and Poor's and Fitch lowered Georgia's sovereign and banks' external debt ratings by one notch.
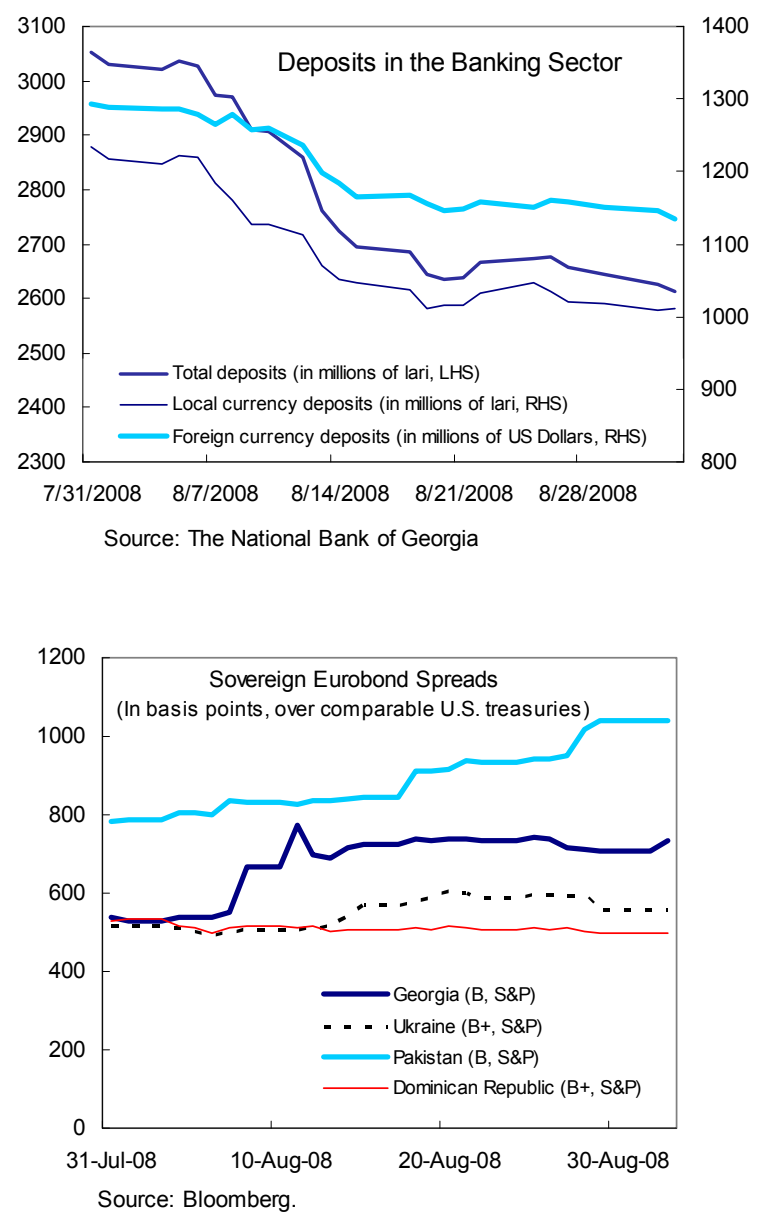


\section{Box 1. Georgia—Actions to Address the Temporary Liquidity Needs}

The authorities introduced the following actions in the wake of the conflict:

- $\quad$ Pegged the exchange rate, on a temporary basis, to calm the market, and intervened heavily in the market to fully meet the demand for foreign exchange.

- Declared a one-day bank holiday on August 12 because of a shortage of dollar banknotes.

- Imposed temporary limits on deposit withdrawals and new credit operations (now lifted). Banks resumed normal operations at end-August.

- Waived the reserve requirements for two consecutive periods with the intention of restoring them gradually.

- $\quad$ Redeemed NBG securities before maturity.

- $\quad$ Activated an uncollateralized lending facility in lari at a penalty interest rate (20 percent) up to a limit of $\$ 200$ million for the system. Three banks used the facility.

- $\quad$ Lowered the NBG policy rate by 100 basis points to signal readiness to keep banks adequately liquid and the financial system functioning.

- $\quad$ The FSA monitored banks daily to identify emerging liquidity pressures, the pace of deposit outflows, and possible relaxation of borrowers' payment discipline.

14. The direct damage to the banking sector seems to have been contained but further liquidity shortages and asset quality deterioration are matters of concern. In response to the tightening of liquidity conditions, banks sharply curtailed their lending, and the pullback in the availability of financing will challenge the sector's growth model and could weaken the quality of individual banks' portfolios. A key concern is credit to construction and mortgages, which accounts for one-fifth of the system's credit, and has boomed, driven by rising real estate prices. This needs to be considered alongside the high reliance on real estate for loan collateral. Maturing external liabilities in the next 12 months are estimated at $\$ 600$ million, about 13 percent of total liabilities. In addition, early repayment clauses attached to some outstanding external loans may be activated if confidence is not fully restored.

\section{The Program}

\section{Georgia's near-term growth prospects have been hit by recent events, but the} economy is well placed to recover from the shock. The impressive record of adjustment and reform over recent years has strengthened the structure of the economy and its ability to deal with the economic consequences of the shock. After having addressed the immediate effects, the authorities are now focusing on adapting their short-term macroeconomic policies to the changing circumstances, with a view to maintaining macroeconomic stability and 
strengthening financial sector soundness. This should help maintain a business climate favorable to investors, facilitate Georgia's reentry into global capital markets, and allow it to quickly return to the path of high economic growth.

16. The Fund SBA is intended to mitigate the impact of the shock on the balance of payments and help restore investor confidence. ${ }^{4}$ Due to the size of the current account deficit and reliance on large FDI inflows to finance it, and the links between foreign inflows and domestic financial intermediation, a large external financing gap has emerged because of the shock. The authorities believe that the Fund support for their policies will provide the needed financial assurances to help restore investor confidence and limit the risk of more serious disruptions. Backed by some adjustment, Fund financing would help replenish gross reserves and address the existing pressures in the capital account.

\section{A. Macroeconomic Framework}

\section{Program discussions centered on a macroeconomic framework that shows a} significant slowdown in private inflows in 2008-09 and a recovery in the medium term. Based on the expectations of foreign investors, the banking sector and the business community, a complete stall or reversal of inflows does not appear likely. Nonetheless, the authorities and the staff project a sharp slowdown in private inflows (FDI, bank loans, portfolio investment), which would decline to $\$ 313$ million in the second half of the year (from $\$ 1.5$ billion in the first half), followed by a moderate recovery to $\$ 1.8$ billion in 2009 (about half of the level expected before the conflict). In 2010 and beyond, private inflows are projected to recover. The decline in inflows (factoring in an associated drop in imports) would lead to a cumulative gap in the balance of payments of about $\$ 1.2$ billion during 2008-09 (see Box 2). The size of the gap is subject to a high degree of uncertainty given the nature of the shock, unpredictability of investor sentiment, and the pace of recovery of foreign inflows.

\begin{tabular}{lrrr}
$\begin{array}{l}\text { Text Table 2. Georgia: Balance of Payments Indicators, 2008-09 } \\
\text { (In millions of USD) }\end{array}$ & \\
\cline { 2 - 4 } & $\begin{array}{r}\text { Jan-Jun 1/ } \\
\text { prel. }\end{array}$ & $\begin{array}{r}\text { Jul-Dec } \\
\text { proj. }\end{array}$ & proj. \\
\hline & $-1,549$ & $-1,208$ & $-2,618$ \\
& 1,531 & 313 & 1,825 \\
\hline Current account (in millions of USD) & 857 & 380 & 1,198 \\
Private capital inflows & 673 & -67 & 628 \\
FDI & & & \\
Non-FDI flows, net & & & \\
(bank loans, portfolio investment and other short-term capital) & & 1,526 & 1,270 \\
Memorandum items: & 1,526 & 920 & 1,755 \\
Gross international reserves (with SBA; in millions of USD) & & \\
Gross international reserves (without SBA; in millions of USD) & & \\
\hline Sources: National Bank of Georgia; and Fund staff projections. & & \\
1/ For the first quarter, official actual data is available. Q2 is based on preliminay estimates.
\end{tabular}

\footnotetext{
${ }^{4}$ Even though Georgia is PRGF eligible, a PRGF is not appropriate at this time because it cannot accommodate the level of high access needed in this case, and Georgia does not require the type of comprehensive reform that a PRGF arrangement is designed to address. Moreover, the requirement of a PRSP would be time consuming.
} 


\section{Box 2. Georgia-Sources of the Balance of Payments Gap}

\section{A financing gap of $\$ 550$ million (about 4 percent of 2008 GDP) will emerge in the second half of 2008 as:}

- A small net outflow (some $\$ 70$ million) of short-term capital (primarily bank loans and portfolio investment) is projected for the second half of the year. This implies a reversal of about $\$ 700$ million (5 $\frac{1}{2}$ percent of GDP) compared to the first six months.

- $\quad$ FDI is anticipated to decline by $\$ 450-\$ 500$ million in the second half of the year compared to the first half. The net impact of the shortfall in FDI on the balance of payments - given its high import content — is estimated at around \$200 million (1 $1 \frac{1}{2}$ percent of GDP).

- $\quad$ The current account deficit is projected to narrow (from $\$ 1.5$ billion in the first half of 2008 to $\$ 1.2$ billion in the second half). Higher reconstruction imports will broadly offset lower imports associated with the economic slowdown, and remittances are projected to increase.

- Whereas gross reserves increased by $\$ 165$ million in the first half of the year, they are expected to fall by $\$ 256$ million in the second half notwithstanding the disbursement of $\$ 350$ million from the SBA.

The $\$ 650$ million (43/4 percent gap of GDP) BOP financing gap projected for 2009 is based on the following assumptions:

- $\quad$ Private capital inflows (including FDI) are expected to recover in 2009 and reach $\$ 1.8$ billion, but will remain well below pre-conflict expectations.

- $\quad$ The spending of the $\$ 370$ million foreign assets of the sovereign wealth funds in 2009 would help lower the financing gap, but the net impact on the BOP would depend on the import content of government spending of these assets.

- $\quad$ The current account would narrow somewhat as exports recovery and strong remittances will offset reconstruction-related imports.

- $\quad$ NBG intervention in the foreign exchange market would contribute to the BOP gap. In contrast to the second half of 2008, the NBG reserves (net of purchases under the SBA) are expected to increase by $\$ 160$ million in 2009 . 
18. The macroeconomic outlook points to considerably slower growth and, in the absence of a Fund program, a continuing loss of gross international reserves.

Text Table 3. Georgia: Macroeconomic Framework, 2007-10

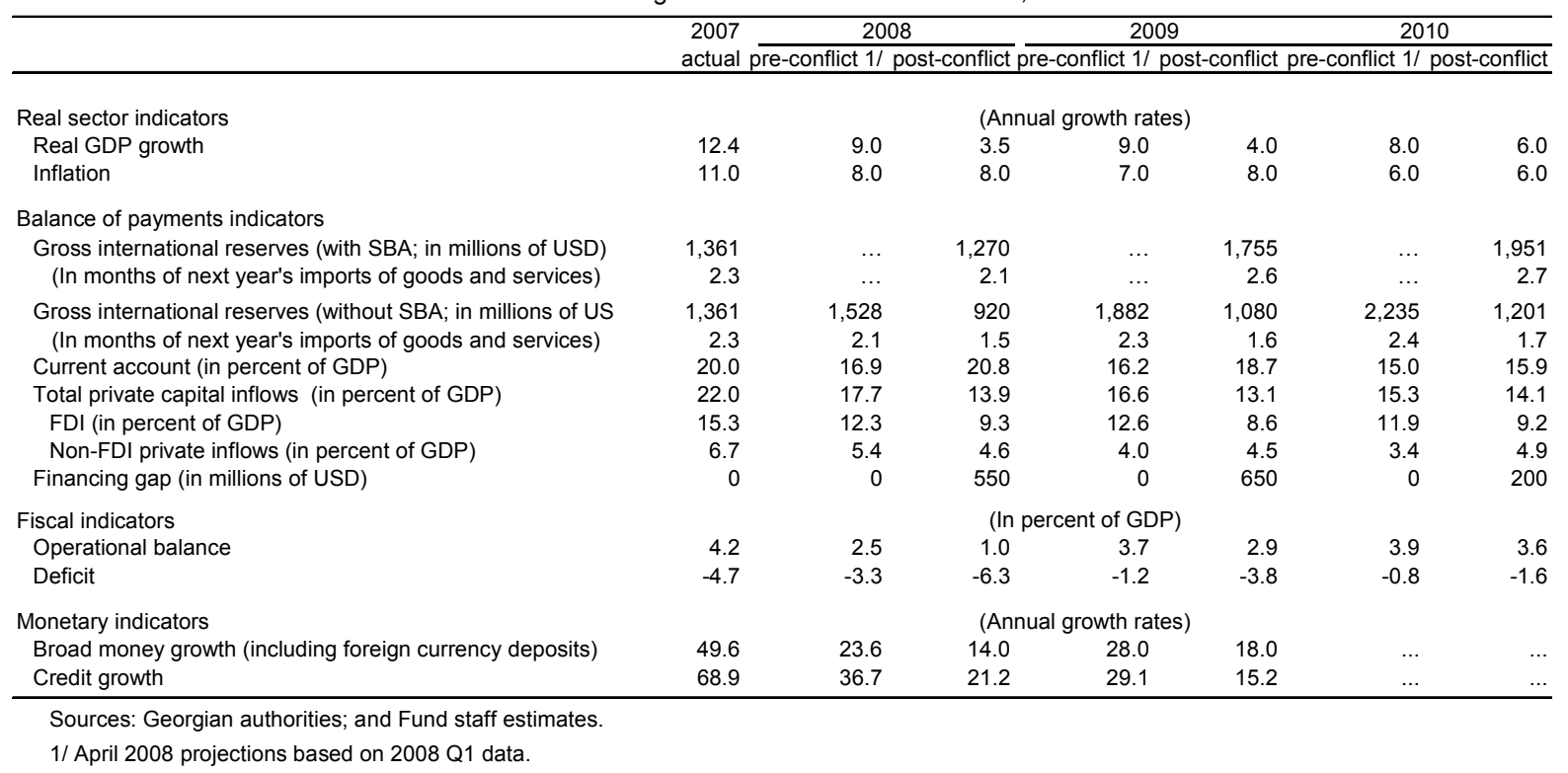

- $\quad$ Real GDP growth would slow to $3 \frac{1}{2}$ percent in 2008 (compared to 9 percent projected before the conflict) driven by a significant drop in private investment and consumption in the remainder of the year. Growth would recover to 4 percent in 2009 and 6 percent in 2010, aided by an upturn in inflows and investment for reconstruction.

- The external current account deficit would reach about $203 / 4$ percent of GDP in 2008, which implies a contraction compared to the first half of the year. It would then narrow to $18 \%$ / percent in 2009 owing mainly to the expected drop in FDIrelated imports, despite increasing reconstruction imports and slower export growth.

- Gross reserves would be used to finance the fourth quarter balance of payments gap. Reserves would further decline to $\$ 920$ million (1.5 months of imports) by end-2008 and remain at about this level of import cover in 2009. The use of Fund resources would allow reserves to be maintained at a more adequate level of $\$ 1.27$ billion by end-2008 and $\$ 1.76$ billion by end-2009, equivalent to 2.6 months of imports, 137 percent of projected reserve money, and 51 percent of projected broad money.

- $\quad$ Even though the NBG expects a one-off hike in prices due to food shortages and transportation disruptions, inflation would likely decline to 8 percent in end-2008 (as predicted before the conflict) given the slowdown in demand. Inflation is projected to remain at this rate in 2009 and decelerate gradually thereafter. 


\section{Program Discussions}

19. Discussions focused on the need to continue implementing sound policies that will be flexible enough to respond quickly to short-term fluctuations in foreign inflows. The envisaged policies to deal with the temporary withdrawal of private sector financing following the conflict consist of strengthening underlying fiscal discipline to limit financing needs and refocus priorities on reconstruction spending; adjusting the monetary stance to protect international reserves while returning to a flexible exchange rate regime as soon as confidence is restored; and ensuring that plans to mitigate potential banking system vulnerabilities are in place. Given the underlying strength of private sector growth prior to the conflict and the expected temporary nature of the shock, the authorities considered that, on balance, policies should rely more on financing than on achieving a sharp contraction of the current account deficit through monetary and fiscal tightening.

\section{A. Entrenching Macroeconomic Stability}

\section{Fiscal Policy}

\section{On the fiscal front, the program is based on strengthening the underlying} position to allow room for higher reconstruction and recovery spending. The authorities recognize that the substantial increase in defense spending in recent years has limited fiscal space. They now intend to cut current spending in a way that would lead to a significant increase in public savings (from 0.3 percent of GDP in the first half of 2008 to 1.7 percent in the second half and 2.9 percent in 2009). In particular, defense spending during the second half of 2008 is expected to drop to less than half the spending in the first half of the year. On the revenue front, the tax-to-GDP ratio is expected to decline reflecting the cuts in income and dividend tax rates approved recently by parliament, which the authorities

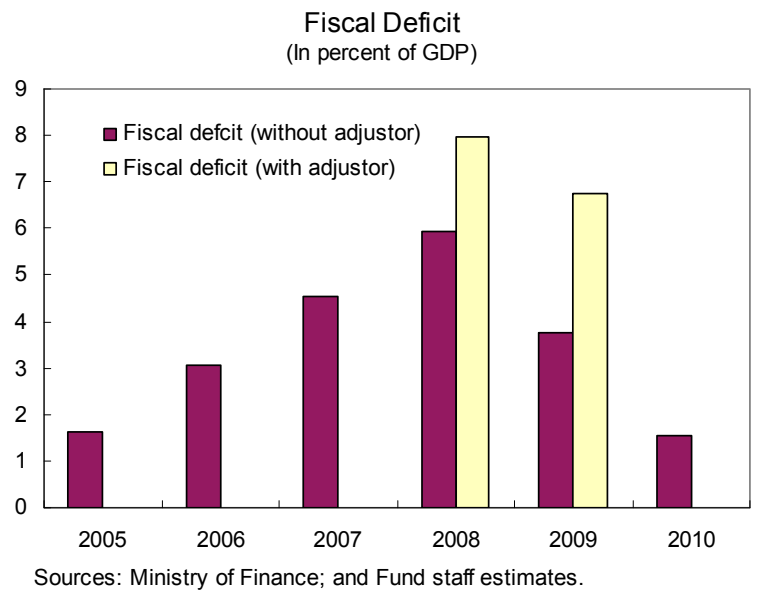
believe are important to maintain private sector confidence. In all, the overall fiscal deficit is set to increase to around 6 percent of GDP in 2008, and to decline to 33/4 percent in 2009 following a further cut in defense spending. These targets provide relatively little room for recovery and reconstruction spending that could be accommodated within the budget, and therefore will be subject to adjustors of up to 2 percent of GDP in 2008 and 3 percent of GDP in 2009 in the event that concessional donor financing exceeds declared pre-conflict commitments. 
Text Table 4. Georgia: Trends in Defense Spending, 2006-09

\begin{tabular}{|c|c|c|c|c|c|c|}
\hline & \multirow[t]{2}{*}{2006} & \multirow[t]{2}{*}{2007} & \multicolumn{3}{|c|}{2008} & \multirow{2}{*}{$\begin{array}{l}2009 \\
\text { proj. 1/ }\end{array}$} \\
\hline & & & $\begin{array}{c}\mathrm{H} 1 \\
\text { spending }\end{array}$ & $\begin{array}{c}\mathrm{H} 2 \\
\text { spending } \\
\text { proj. }\end{array}$ & $\begin{array}{l}\text { Total } \\
\text { proj. }\end{array}$ & \\
\hline \multicolumn{7}{|l|}{ Defense spending } \\
\hline In millions of lari & 689 & 1,496 & 1,053 & 492 & 1,545 & 1,000 \\
\hline In percent of GDP & 5.0 & 8.8 & $\ldots$ & $\ldots$ & 8.0 & 4.6 \\
\hline
\end{tabular}

Source: Ministry of Finance.

$1 /$ This preliminary estimate was used in the Basic Data and Directions Document, which is the MoF's medium-term budget framework, published in spring 2008.

\section{The fiscal deficits will be largely financed by privatization proceeds and use of} government deposits, and complemented by additional donor financing. While the large privatization proceeds that financed the deficit in the last few years are expected to slow, these receipts, along with the use of government deposits, are expected to finance the 200809 deficits. For this purpose, in the fourth quarter of 2008, the government plans to use the $\$ 130$ million of the Eurobond proceeds that are deposited in a NBG account, and in 2009 it will use the $\$ 370$ million (remainder of the Eurobond proceeds) that it holds in the sovereign wealth funds. In line with its fiscal consolidation strategy, the government has been using external and domestic borrowing carefully and does not have significant disbursements in the pipeline. As such, the identified financing and grants are modest, and there is therefore a need for donor support for the reconstruction and relief effort. Some donors have announced their intention to provide assistance. The U.S. has pledged a $\$ 1$ billion multi-year package, of which about half has been identified as additions to the Millennium Challenge grants, investment guarantees, humanitarian assistance, and budget support (\$210-\$240 million); and the World Bank has identified additional budget support of $\$ 30$ million. The EU, EBRD, and ADB are also considering supporting pledges. However, the size, pace, and composition of all donor support are not yet fully defined.

\section{The authorities are planning to give an additional push to structural fiscal}

reforms. They intend to submit to parliament an organic budget system law, thereby locking in significant rule-based limits on fiscal policy. ${ }^{5}$ The authorities see this as an essential tool to curtail unproductive spending in the face of the difficult geopolitical environment, and to limit state agencies' deviations from budgeted spending. They also plan to improve the medium-term public expenditure strategy, complete the implementation of a risk

\footnotetext{
${ }^{5}$ The authorities indicated that an organic law requires a qualified majority for parliament to amend it, and takes precedence over normal laws such as the annual budget law.
} 
management system for tax and customs administration, and strengthen transparency in the fiscal accounts (see paragraphs 24 to 31 of the MEFP).

\section{Monetary and Exchange Rate Policy}

23. In the very short term, the NBG will continue to focus on meeting the unusually high liquidity needs of the banking system. To address the tight monetary conditions resulting from the deposit withdrawal and slowdown in foreign inflows, which are expected to return gradually to normal, the NBG introduced a 7-day refinancing facility collateralized by government and central bank securities at interest rates determined in weekly auctions. Given that the existing stock of collateral in the market (about 165 million lari) may not suffice to meet the immediate needs, the authorities are considering the establishment of an (unsecured) credit facility at penalty rates to meet potential additional liquidity shortages and possibly a temporary reduction of the reserve requirement (to replace the current waiver). An important factor affecting liquidity conditions going forward will be the banks' willingness to resume lending to the private sector, which has been brought to a near halt in the current uncertain environment.

\section{The authorities are determined to avoid an excessive reserve loss by} reintroducing exchange rate flexibility as soon as the situation in the banking system has stabilized. They are aware of the pressures that continued liquidity injections could place on the foreign exchange market and international reserves. Accordingly, they will monitor closely monetary conditions to achieve the net international reserves floors set in the program. In the aftermath of the conflict, the NBG intervened heavily in the foreign exchange market as it viewed exchange rate stability as essential for maintaining depositor confidence and limiting the risks from the large foreign currency exposure. Nonetheless, as market conditions become more stable (e.g. when deposit outflows stop), the exchange rate will have to adjust to the expected lower supply of foreign exchange. Prior to the conflict, staff's analysis pointed to moderate overvaluation of the real effective exchange rate and suggested that the large current account deficit posed some risks to external stability. The authorities' commitment to sound policies and far-reaching structural reforms to maintain external competitiveness should contribute to limiting this risk.

25. A framework for liquidity management is a renewed priority for the NBG. The need to shift policies quickly (from mopping to injecting liquidity) has highlighted the advantage of having a well-structured liquidity framework, compared to the current use of ad-hoc instruments to deal with changing circumstances. The NBG is committed to developing such a scheme to enhance the efficiency of monetary policy and to strengthen the transmission mechanism in preparation for the envisaged formal inflation-targeting regime (see paragraph 32 of the MEFP). 


\section{Debt Issues}

26. The staff's debt sustainability analysis shows that Georgia's external debt is low and will remain sustainable despite the adverse impact of the conflict. Public debt will rise in 2008-09 on account of the \$500 million Eurobond and the new conflict-related borrowing. Over the long term, all relevant debt solvency and liquidity indicators are well below the applicable thresholds and show resiliency to a number of stress tests. The large projected debt service in 2012-13 is a risk to the debt outlook (see Attachment IV). ${ }^{6}$

\section{B. Strengthening Financial Sector Soundness}

27. Aided by tight prudential requirements, the banking system has been resilient to the current pressures, but there are concerns about liquidity and asset quality. The current downturn was cushioned by strong prudential ratios, including high liquidity requirements, stringent capital adequacy ratios (12 percent), and higher risk weighting for foreign-currency lending. ${ }^{7}$ However, the maturing external liabilities and slow deposit growth could put additional pressure on liquidity and funding if foreign financing remains inaccessible in this environment. Also, there are concerns about the impact of the economic slowdown on banks' indirect foreign exchange rate exposure and asset quality, particularly given their large exposure to the real estate sector.

28. In the face of these challenges, clear action plans need to be developed to assess bank vulnerabilities and mitigate risks. The supervisory authorities are working with banks on plans to maintain liquidity, preserve asset quality, and meet solvency standards, including, if necessary, by raising additional capital. These plans will be assessed in the context of subsequent program reviews. The FSA needs to ensure that banks are realistically assessing their business position, adequately provisioning for rising NPLs, and taking a conservative approach to collateral valuations in an environment of limited liquidity and falling prices in the property market.

29. To support these efforts, there is a need to build up the capacity of the FSA. Efforts by the FSA to step up bank supervision in the wake of the conflict have been successful, and are expected to be complemented by upgrading offsite supervisory capacities based on deeper analysis and additional bank inspections when issues of concern arise. The authorities intend to enhance risk management practices by banks and strengthen supervision on a consolidated basis to avoid regulatory arbitrage, and to align financial sector regulation

\footnotetext{
${ }^{6}$ A joint debt sustainability analysis with the World Bank will be carried out in the context of the next Article IV consultation.

${ }^{7}$ According to the FSA, the banks' loan-loss provisioning would have to increase two-fold to bring the capital adequacy ratio down to a minimum 12 percent.
} 
to the recent changes in legislation. They also have plans to further enhance the independence of the FSA (see paragraph 43 of the MEFP).

30. The authorities intend to strengthen the lender of last resort (LOLR) facility to reduce incentives for excessive risk taking by banks and safeguard the strength of the NBG's balance sheet. The NBG's emergency liquidity provision instruments were effective in providing short-term support to banks during the recent turbulence. Going forward, however, the authorities see the crucial need to strengthen the LOLR, including by refining the type of securities that can be used as collateral, redefining access limits and maturity, and ensuring that emergency liquidity is provided only to solvent and viable banks. The FSA has an important role to play in determining that banks only face liquidity difficulties and in exercising oversight on the institutions accessing the facility.

31. Cooperation between the NBG and the FSA will be enhanced. Both institutions are working on a memorandum of understanding that will define roles and responsibilities, and introduce practical and legal arrangements for information exchange (see paragraph 42 of the MEFP).

\section{Risks to the Program}

32. Even though the authorities are committed to maintaining macroeconomic stability, considerable downside risks remain. Escalations of regional or domestic tensions or a less benign international economic environment are major risks for this program. These events could result in a greater-than-anticipated deterioration of investor confidence that could add pressures to the capital account. If events trigger a loss of depositors' confidence, a prolonged period of tight liquidity and credit conditions and a worsening of credit portfolio could result in a weakening of bank soundness.

33. The program is based on a macroeconomic scenario under which the outlook remains difficult, but a full-blown crisis does not erupt. The authorities indicated that they stand ready to implement additional measures as needed in consultation with Fund staff. These measures would depend on how the circumstances develop. There could be a need to tighten monetary and fiscal policies, allow for faster exchange rate depreciation, and seek additional financing to react to a larger-than-anticipated shock. The mission discussed with the authorities the need to strengthen the bank resolution framework - in particular, to clarify the roles that the NBG, the FSA, and the government would play if banking difficulties of systemic importance were to arise.

\section{Program Access, Monitoring, and Capacity to Repay the Fund}

34. The proposed SBA would involve exceptional access. In light of the significant contribution of foreign inflows to the capital account, the shock to confidence has already produced large external financing needs that have been covered by a loss of 23 percent of international reserves (140 percent of quota). In addition, inflows are not expected to fully 
recover until the security situation stabilizes, adding to the financing gap. Staff believes that Georgia meets the four criteria for exceptional access (see Attachment V).

35. The external financing gap is expected to be filled by the Fund and other donors' support. The program envisages that the SBA will fill about 60 percent of the 2008-09 financing gap, with the remainder expected to be met by donors, who are now assessing the size, pace, and modalities of their contribution. In 2008, the SBA will cover $\$ 350$ million of the $\$ 550$ million financing gap, the World Bank will contribute $\$ 30$ million, and the U.S. the remaining $\$ 170$ million. ${ }^{8}$ Details of how the 2009 financing gap will be closed will be provided at the time of the first program review.

36. Georgia has established a record of timely servicing its obligations to the Fund, and its capacity to repay is expected to remain strong. The public external debt-to-GDP ratio is projected at 25 percent of GDP by 2010, even amid a marked slowdown in economic growth. This ratio includes the impact of the drawdown of the full amount of the proposed SBA $\left(2 \frac{1}{2}\right.$ and $2 \frac{1}{4}$ percentage points of the external public debt-to-GDP ratio in 2008 and 2009, respectively) as well as the effect of the Eurobond issue and the conflict-related borrowing. Based on these debt indicators, Georgia's capacity to repay the Fund is strong. Nevertheless, this capacity would be substantially impaired if any of the downsize risks of the program materialize.

37. Conditionality is proposed to be driven by the authorities' reform agenda, and is considered critical to achieve the program objectives. The program includes two key structural performance criteria and four structural benchmarks to be completed in the next nine months focused on macroeconomic and financial sector soundness (see Box 3). Additional structural conditionality to follow up on these objectives will be discussed during future program reviews.

\section{An updated safeguards assessment of the NBG has been initiated and will be} completed no later than the first review. Staff monitoring since the previous safeguards assessment (2004) indicates that the NBG continues to comply with key safeguards requirements. The NBG publishes IFRS financial statements that have been externally audited in accordance with international standards. The update would aim to confirm the findings of the off-site monitoring and identify any emerging safeguards issues.

\footnotetext{
${ }^{8}$ The U.S. contribution in 2008 may be larger. However, the amount of cash disbursements is unknown, as a significant part of the pledges is expected to be associated with imports.
} 


\section{Box 3. Georgia: The New Stand-By Arrangement}

Objective of the Program. Finance the external gap emerging from pressures to the balance of payments and provide the needed financial assurances to help restore investor confidence.

Access. SDR 477.1 million

Phasing. SDR 161.7 million will be made available upon the Board's approval of the arrangement to address the urgent need to replenish reserves. Subsequent two tranches of SDR 63.1 million each could be made available in November 2008 and February 2009. Thereafter, the program builds on four equal purchases of SDR 47.3 million made available on a quarterly basis.

\section{Conditionality}

\section{Quantitative Performance Criteria}

A ceiling on the financing of the overall fiscal balance.

A floor on the NBG's net international reserves.

A ceiling on the net domestic assets of the NBG.

A ceiling on the contracting or guaranteeing of new nonconcessional external debt. Nonaccumulation of public external arrears during the program period.

\section{Structural Performance Criteria}

Introduction by the NBG of a LOLR facility (critical for liquidity management in the face of financial sector vulnerabilities).

Submission to parliament of a new organic budget system law (critical for ensuring fiscal discipline and boosting investor confidence in the wake of the conflict).

\section{Structural Benchmarks (critical for strengthening fiscal and financial institutions).}

FSA and NBG to sign and implement a memorandum of understanding to strengthen cooperation.

Submission to parliament of a state budget for 2009 with an overall deficit of no more than $3 \frac{3}{4}$ percent of GDP (subject to an adjustor for donor-financed reconstruction spending of up to 3 percent of GDP).

NBG to develop and publish a liquidity management framework.

Appointment of the remaining members of the FSA Board.

Expected Reviews: Quarterly reviews and quarterly performance criteria. 
39. During the period of the arrangement, the authorities will maintain the usual close policy dialogue with the Fund. Georgia's office was downsized in August 2008, and there is currently no resident representative. Until the post is filled, the senior resident representative in Lebanon will visit Tbilisi periodically to help monitor the program.

\section{StAFF APPRAISAL}

40. Georgia's economy is well positioned to deal with the temporary shock it is facing. Its impressive record of adjustment and reform has strengthened the structure of the economy and its ability to address the economic consequences of the recent armed conflict. The overall policy framework prior to the conflict was sound and the immediate response to the shock was appropriate and consistent with Fund's advice. Now the authorities are centering their attention on restoring investor confidence to allow Georgia to return to the path of high economic growth as quickly as possible. Financing of the balance-of-payments gap is critical toward this end.

41. The authorities see Fund's support for their program as an essential piece of their strategy. Fund resources will not only replenish the large loss in gross international reserves since the conflict erupted and help finance the 2009 financing gap, but would also act as a catalyst to boost investor confidence and facilitate other donors' support for the reconstruction effort.

42. The proposed program involves exceptional access since it would exceed limits of 100 percent of quota annually and 300 percent of quota cumulatively. Georgia's case meets the criteria for such an access given that the drop in inflows is placing exceptional pressures on the capital account, the debt position is sustainable even after the required postconflict financing, renewed access to private capital markets after conditions stabilize is likely, and the authorities are committed to sound reforms, although there are risks regarding the prevailing geopolitical situation.

43. The Fund program will support the authorities' efforts to limit the deterioration in the external account by containing the fiscal deficit and maintaining a vigilant monetary stance, while strengthening financial sector resilience. Given the temporary nature of the shock and the strength of the underlying macroeconomic conditions going into the conflict, the program targets only a moderate adjustment in the current account in 200809. Dealing with the external imbalance through a sharp tightening of fiscal and monetary policies at this stage would carry excessive costs. The program supports the authorities' short-term strategy of avoiding liquidity disruptions and accepting higher fiscal spending on reconstruction, while retaining the main direction of economic policies in place prior to the conflict.

44. On fiscal policy, the plan is to reduce current expenditures in order to free resources for relief and reconstruction, and move as planned with reductions in the tax burden. This strategy would allow for a more efficient expenditure mix, and along with tax 
administration improvements, would lead to a sustainable fiscal position in the medium term. As the authorities have stressed, reversing the already announced income tax rate cut could give the wrong signal to investors at a time when reassuring them of the government's probusiness policies is essential for restoring investor confidence. Capital expenditure will be led by reconstruction and infrastructure needs. The 2008-09 deficits are anticipated to be mainly financed by the use of resources deposited in the sovereign wealth fund (proceeds from the $\$ 500$ million Eurobond issue early this year) and privatization receipts. Concessional loans and grants to be provided by multilateral and bilateral partners - in an amount that is still uncertain at this time-are expected to finance further reconstruction needs, and will be accommodated within the fiscal targets.

45. Monetary policy has to deal with the dilemma of providing sufficient liquidity to the banking system while stabilizing the exchange rate and protecting the international reserve position. The authorities have adjusted some of their policy instruments to inject liquidity in the face of deposit withdrawals and lower capital inflows. However, given the limited international reserve buffer, continued provision of liquidity could undermine the central bank's ability to stabilize the exchange rate and with it inflationary expectations. The staff supports the authorities' policy of avoiding short-term volatility in the exchange rate, but stresses the importance of the program's floors on net international reserves and the need to return to a flexible exchange rate regime as soon as market conditions allow. This might require raising interest rates further. To facilitate a return to more normal liquidity conditions, the authorities' plans to phase out the reserve requirement waiver introduced in the wake of the conflict and to make progress in strengthening liquidity management and improving the LOLR facility during the first six months of the program are crucial. With the expected slowdown in economic activity, inflation is expected to remain moderate. The introduction of an inflation-targeting regime should help anchor inflation over the medium term.

\section{The banking system has been resilient to the current pressures, but there are} concerns about liquidity and asset quality. To address these challenges, the supervisory authorities are planning to work with banks on plans to assess bank vulnerabilities and mitigate risks. To support these efforts, the program envisages actions to build up the capacity of the FSA, strengthen its independence, and enhance cooperation between the NBG and the FSA. Once market uneasiness subsides, there is a need to improve contingency planning for bank resolution.

47. Risks to the program are considerable. Escalations of regional or domestic tensions and a less benign international economic environment are major risks, as these events could be followed by a greater-than-anticipated deterioration of investor confidence that could add pressures to the capital account. A weakening of bank asset quality and reduced access to foreign borrowing is another substantive risk for the macroeconomic outlook and the program. If these scenarios emerge, the authorities are prepared to act quickly by strengthening policies and mobilizing financing. 
Figure 1. Georgia: Financial Indicators
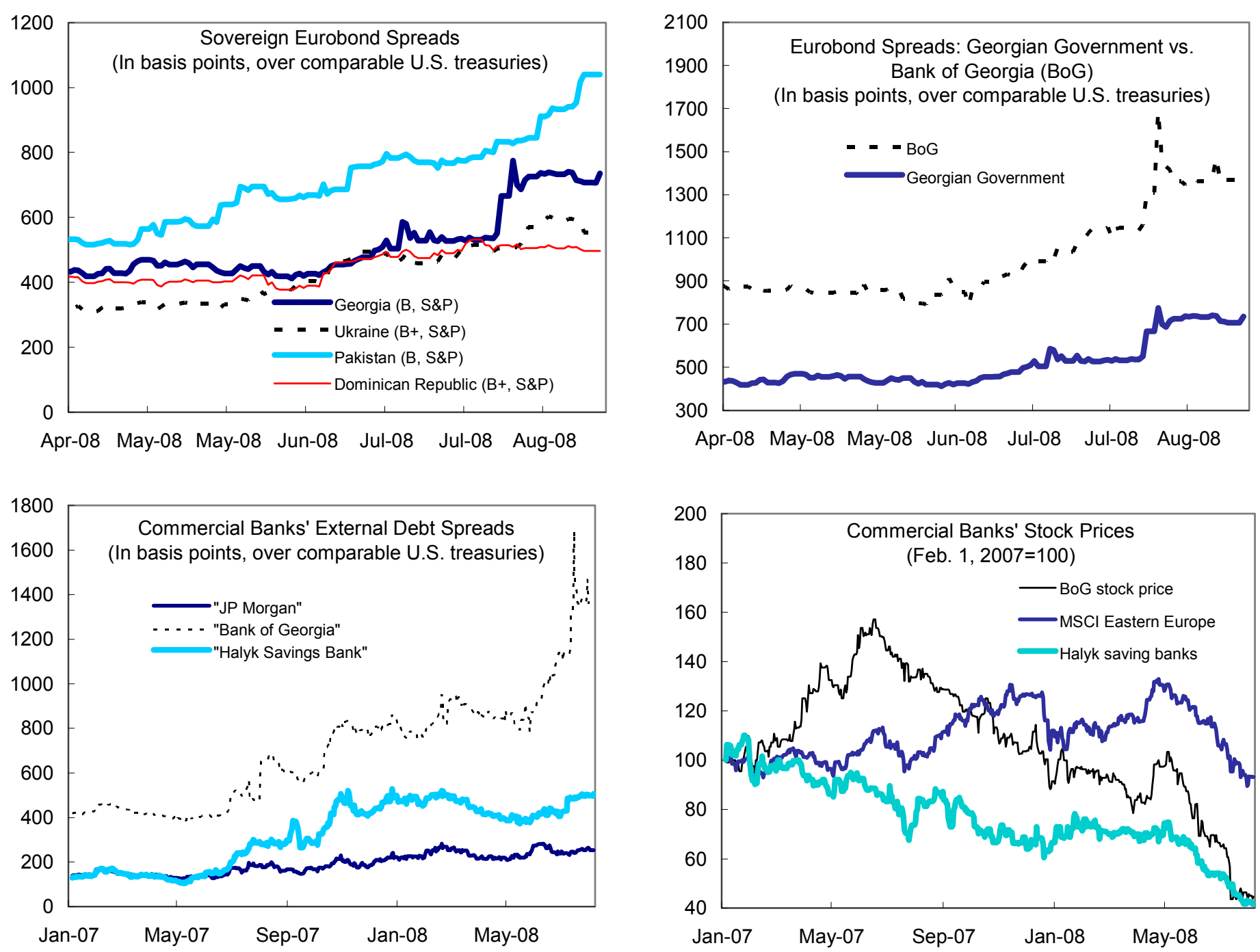

Source: Bloomberg. 
Figure 2. Georgia: Monetary Indicators
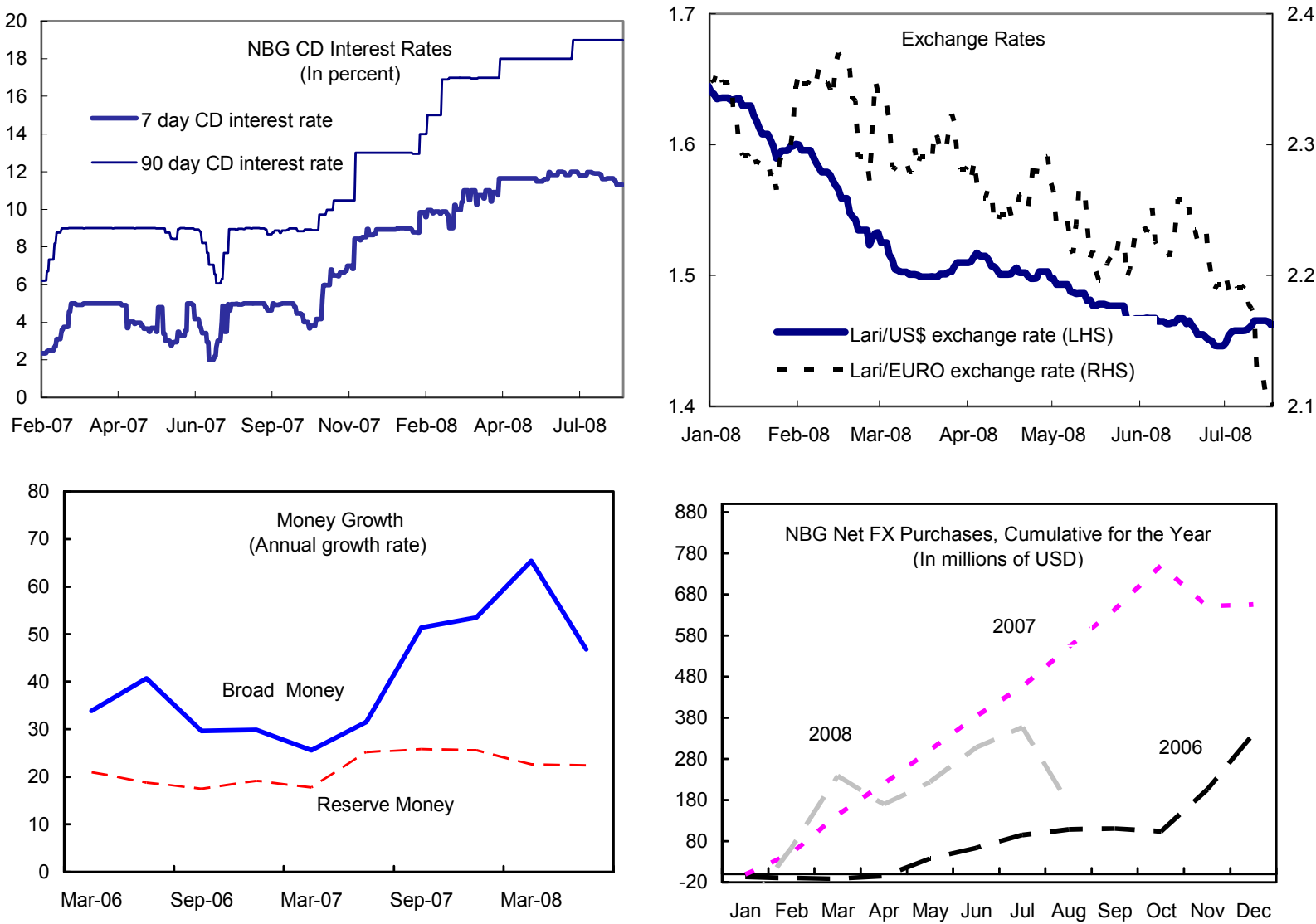

Jan Feb Mar Apr May Jun Jul Aug Sep Oct Nov Dec
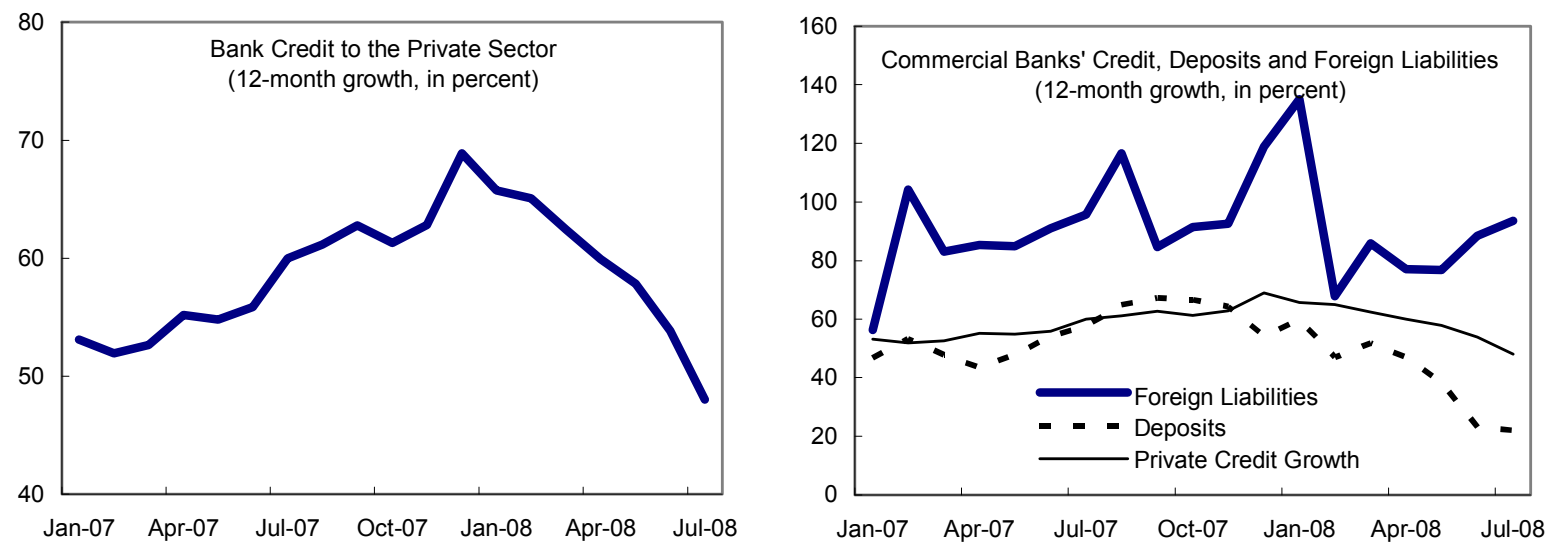

Sources: National Bank of Georgia; and Bloomberg. 
Table 1. Georgia: Selected Macroeconomic Indicators, 2006-12

\begin{tabular}{|c|c|c|c|c|c|c|c|}
\hline & $\begin{array}{r}2006 \\
\text { Act. }\end{array}$ & $\begin{array}{l}2007 \\
\text { Prel. }\end{array}$ & $\begin{array}{c}2008 \\
\text { Proj. }\end{array}$ & $\begin{array}{c}2009 \\
\text { Proj. }\end{array}$ & $\begin{array}{r}2010 \\
\text { Proj. }\end{array}$ & $\begin{array}{l}2011 \\
\text { Proj. }\end{array}$ & $\begin{array}{r}2012 \\
\text { Proj. }\end{array}$ \\
\hline & \multicolumn{7}{|c|}{ (Annual percentage change, unless otherwise indicated) } \\
\hline \multicolumn{8}{|l|}{ National accounts } \\
\hline Real GDP growth & 9.4 & 12.4 & 3.5 & 4.0 & 6.0 & 6.0 & 7.0 \\
\hline Population (million) $1 /$ & 4.3 & 4.4 & 4.4 & 4.4 & 4.4 & 4.4 & 4.4 \\
\hline Consumer price index, period average & 9.2 & 9.2 & 10.0 & 7.6 & 7.0 & 6.0 & 6.0 \\
\hline Consumer price index, end-of-period & 8.8 & 11.0 & 8.0 & 8.0 & 6.0 & 6.0 & 6.0 \\
\hline GDP per capita (US\$) & 1,800 & 2,324 & 2,895 & 3,167 & 3,592 & 4,036 & 4,577 \\
\hline Poverty rate (in percent) & 31.0 & $\ldots$ & $\ldots$ & $\ldots$ & $\ldots$ & $\ldots$ & $\ldots$ \\
\hline Unemployment rate (in percent) & 13.6 & 13.3 & $\cdots$ & $\ldots$ & $\ldots$ & $\ldots$ & $\ldots$ \\
\hline & \multicolumn{7}{|c|}{ (In percent of GDP) } \\
\hline \multicolumn{8}{|l|}{ Investment and saving } \\
\hline Investment & 25.6 & 28.1 & 23.7 & 22.2 & 22.4 & 24.0 & 25.1 \\
\hline Public & 2.5 & 3.4 & 3.6 & 5.6 & 4.0 & 4.2 & 4.3 \\
\hline Private & 23.0 & 24.7 & 20.1 & 16.6 & 18.4 & 19.8 & 20.8 \\
\hline Gross national saving & 9.7 & 8.1 & 2.9 & 3.5 & 6.5 & 9.8 & 12.7 \\
\hline Public & 5.9 & 4.2 & 1.0 & 2.9 & 3.6 & 4.2 & 4.2 \\
\hline Private & 3.7 & 3.8 & 1.9 & 0.6 & 2.8 & 5.6 & 8.5 \\
\hline Saving-investment balance & -15.9 & -20.0 & -20.8 & -18.7 & -15.9 & -14.2 & -12.4 \\
\hline & \multicolumn{7}{|c|}{ (In percent of GDP) } \\
\hline \multicolumn{8}{|l|}{ Consolidated government operations } \\
\hline Revenue & 26.7 & 29.2 & 27.7 & 26.0 & 25.5 & 25.1 & 25.0 \\
\hline Expenses & 20.8 & 25.0 & 26.6 & 23.1 & 21.8 & 20.9 & 20.8 \\
\hline Operational balance & 5.9 & 4.2 & 1.0 & 2.9 & 3.6 & 4.2 & 4.2 \\
\hline Capital spending and net lending & 9.0 & 9.0 & 7.3 & 6.7 & 5.2 & 4.8 & 4.5 \\
\hline Total balance & -3.0 & -4.7 & -6.3 & -3.8 & -1.6 & -0.6 & -0.3 \\
\hline Statistical discrepancy & 0.0 & 0.2 & 0.3 & 0.0 & 0.0 & 0.0 & 0.0 \\
\hline Total financing (program definition) & 3.0 & 4.5 & 5.9 & 3.8 & 1.6 & 0.6 & 0.3 \\
\hline Domestic & -1.7 & -0.9 & 1.3 & -0.3 & -0.3 & -0.2 & -0.2 \\
\hline External & -0.4 & 0.2 & 1.5 & 3.1 & 0.8 & 0.3 & 0.4 \\
\hline Of which: use of Sovereign Wealth Fund resources & 0.0 & 0.0 & -2.8 & 2.5 & 0.0 & 0.0 & 0.0 \\
\hline Privatization receipts & 5.2 & 5.2 & 3.2 & 0.9 & 1.0 & 0.6 & 0.1 \\
\hline & \multicolumn{7}{|c|}{ (Annual percentage change, unless otherwise indicated) } \\
\hline \multicolumn{8}{|l|}{ Monetary sector } \\
\hline Reserve money & 19.2 & 25.6 & 19.0 & 12.0 & $\ldots$ & $\ldots$ & $\ldots$ \\
\hline Broad money (including foreign exch. deposits) & 39.3 & 49.6 & 14.0 & 18.0 & $\ldots$ & $\ldots$ & $\ldots$ \\
\hline Private credit & 53.4 & 68.9 & 21.2 & 15.2 & $\ldots$ & $\ldots$ & $\ldots$ \\
\hline \multicolumn{8}{|l|}{ External sector } \\
\hline Exports of goods and services (percent of GDP) & 33.1 & 31.7 & 27.6 & 29.2 & 30.4 & 30.2 & 29.4 \\
\hline Annual percentage change & 17.6 & 26.1 & 13.1 & 11.5 & 17.5 & 11.5 & 10.5 \\
\hline Imports of goods and services (percent of GDP) & 56.8 & 57.8 & 53.4 & 52.9 & 50.5 & 48.6 & 45.5 \\
\hline Annual percentage change & 33.0 & 34.0 & 20.0 & 4.1 & 7.9 & 8.0 & 6.3 \\
\hline Current account balance (in millions of US\$) & $-1,235$ & $-2,047$ & $-2,757$ & $-2,618$ & $-2,513$ & $-2,510$ & $-2,501$ \\
\hline In percent of GDP & -15.9 & -20.0 & -20.8 & -18.7 & -15.9 & -14.2 & -12.4 \\
\hline Gross international reserves (in millions of US\$) & 881 & 1,361 & 1,270 & 1,755 & 1,951 & 2,080 & 2,173 \\
\hline In months of next year's imports of goods and services & 1.8 & 2.3 & 2.1 & 2.6 & 2.7 & 2.7 & 2.7 \\
\hline Foreign direct investment (percent of GDP) & 13.9 & 15.3 & 9.3 & 8.6 & 9.2 & 9.2 & 8.5 \\
\hline
\end{tabular}

Sources: Georgian authorities; and Fund staff estimates.

1/ Excludes Abkhazia residents. 
Table 2: Georgia: Annual Consolidated Government Operations, 2006-10 1/

\begin{tabular}{|c|c|c|c|c|c|c|c|c|c|c|}
\hline & 2006 & 2007 & 2008 & 2009 & 2010 & 2006 & 2007 & 2008 & 2009 & 2010 \\
\hline & \multicolumn{5}{|c|}{ (In millions of lari) } & \multicolumn{5}{|c|}{ (In percent of GDP) } \\
\hline Revenues & 3,678 & 4,972 & 5,356 & 5,644 & 6,279 & 26.7 & 29.2 & 27.7 & 26.0 & 25.5 \\
\hline Taxes & 3,152 & 4,390 & 4,778 & 5,169 & 5,835 & 22.9 & 25.8 & 24.7 & 23.8 & 23.7 \\
\hline Direct & 1,351 & 1,936 & 2,083 & 2,195 & 2,440 & 9.8 & 11.4 & 10.8 & 10.1 & 9.9 \\
\hline Indirect & 1,801 & 2,454 & 2,695 & 2,974 & 3,396 & 13.1 & 14.4 & 13.9 & 13.7 & 13.8 \\
\hline Other revenues & 358 & 480 & 402 & 297 & 298 & 2.6 & 2.8 & 2.1 & 1.4 & 1.2 \\
\hline \multirow[t]{2}{*}{ Grants } & 168 & 102 & 176 & 178 & 146 & 1.2 & 0.6 & 0.9 & 0.8 & 0.6 \\
\hline & 0 & 0 & 0 & 0 & 0 & 0 & 0 & 0 & 0 & 0 \\
\hline Current expenditure & 2,861 & 4,254 & 5,157 & 5,013 & 5,381 & 20.8 & 25.0 & 26.6 & 23.1 & 21.8 \\
\hline Compensation for employees & 565 & 676 & 1,022 & 1,079 & 1,160 & 4.1 & 4.0 & 5.3 & 5.0 & 4.7 \\
\hline Use of goods and services & 774 & 1,580 & 1,754 & 1,527 & 1,556 & 5.6 & 9.3 & 9.1 & 7.0 & 6.3 \\
\hline Subsidies & 387 & 399 & 391 & 341 & 387 & 2.8 & 2.3 & 2.0 & 1.6 & 1.6 \\
\hline Grants & 7 & 14 & 12 & 10 & 11 & 0.0 & 0.1 & 0.1 & 0.0 & 0.0 \\
\hline Social expenses & 709 & 851 & 1,238 & 1,368 & 1,552 & 5.1 & 5.0 & 6.4 & 6.3 & 6.3 \\
\hline Other expenses & 317 & 636 & 602 & 521 & 590 & 2.3 & 3.7 & 3.1 & 2.4 & 2.4 \\
\hline Interest & 104 & 98 & 137 & 168 & 125 & 0.8 & 0.6 & 0.7 & 0.8 & 0.5 \\
\hline To nonresidents & 36 & 39 & 79 & 110 & 59 & 0.3 & 0.2 & 0.4 & 0.5 & 0.2 \\
\hline To residents & 68 & 59 & 59 & 58 & 66 & 0.5 & 0.3 & 0.3 & 0.3 & 0.3 \\
\hline Operational balance & 817 & 718 & 198 & 631 & 898 & 5.9 & 4.2 & 1.0 & 2.9 & 3.6 \\
\hline Capital spending and net lending & 1,237 & 1,524 & 1,410 & 1,446 & 1,280 & 9.0 & 9.0 & 7.3 & 6.7 & 5.2 \\
\hline Capital & 1,070 & 1,465 & 1,325 & 1,421 & 1,247 & 7.8 & 8.6 & 6.8 & 6.5 & 5.1 \\
\hline Net lending & 167 & 59 & 85 & 25 & 33 & 1.2 & 0.3 & 0.4 & 0.1 & 0.1 \\
\hline Total balance & -420 & -806 & $-1,211$ & -815 & -382 & -3.0 & -4.7 & -6.3 & -3.8 & -1.6 \\
\hline Statistical discrepancy & $\ldots$ & 33 & 60 & 0 & 0 & $\ldots$ & 0.2 & 0.3 & 0.0 & 0.0 \\
\hline Total financing & 420 & 773 & 1,151 & 815 & 382 & 3.0 & 4.5 & 5.9 & 3.8 & 1.6 \\
\hline Domestic & -237 & -149 & 242 & -67 & -67 & -1.7 & -0.9 & 1.3 & -0.3 & -0.3 \\
\hline Amortization & -64 & -30 & -61 & -67 & -67 & -0.5 & -0.2 & -0.3 & -0.3 & -0.3 \\
\hline Use of deposits at the NBG and banks & -173 & -119 & 303 & 0 & 0 & -1.3 & -0.7 & 1.6 & 0.0 & 0.0 \\
\hline External & -62 & 34 & 283 & 681 & 198 & -0.4 & 0.2 & 1.5 & 3.1 & 0.8 \\
\hline Borrowing & 173 & 166 & 920 & 232 & 282 & 1.3 & 1.0 & 4.8 & 1.1 & 1.1 \\
\hline Repayment & -234 & -132 & -96 & -92 & -85 & -1.7 & -0.8 & -0.5 & -0.4 & -0.3 \\
\hline Use of Sovereign Wealth Fund resources & 0 & 0 & -541 & 541 & 0 & 0.0 & 0.0 & -2.8 & 2.5 & 0.0 \\
\hline Privatization receipts & 719 & 889 & 624 & 200 & 252 & 5.2 & 5.2 & 3.2 & 0.9 & 1.0 \\
\hline \multicolumn{11}{|l|}{ Memorandum item: } \\
\hline Nominal GDP & 13,784 & 16,999 & 19,353 & 21,737 & 24,654 & $\ldots$ & $\ldots$ & $\ldots$ & $\ldots$ & $\ldots$ \\
\hline \multicolumn{11}{|l|}{ Total financing including adjustor } \\
\hline Adjustor & & & 387 & 652 & & & & 2.0 & 3.0 & \\
\hline \multirow[t]{2}{*}{ Adjusted deficit ceiling } & $\ldots$ & $\ldots$ & 1,538 & 1,467 & $\ldots$ & $\ldots$ & $\ldots$ & 7.9 & 6.8 & $\ldots$ \\
\hline & $\cdots$ & $\ldots$ & $\cdots$ & $\ldots$ & $\ldots$ & $\cdots$ & $\ldots$ & $\cdots$ & $\ldots$ & $\ldots$ \\
\hline
\end{tabular}

Source: Ministry of Finance; and Fund staff estimates.

1/ Consolidated government includes central and local governments and the Sovereign Wealth Funds. 
Table 3. Georgia: Quarterly Consolidated Government Operations, 2008-09 1/

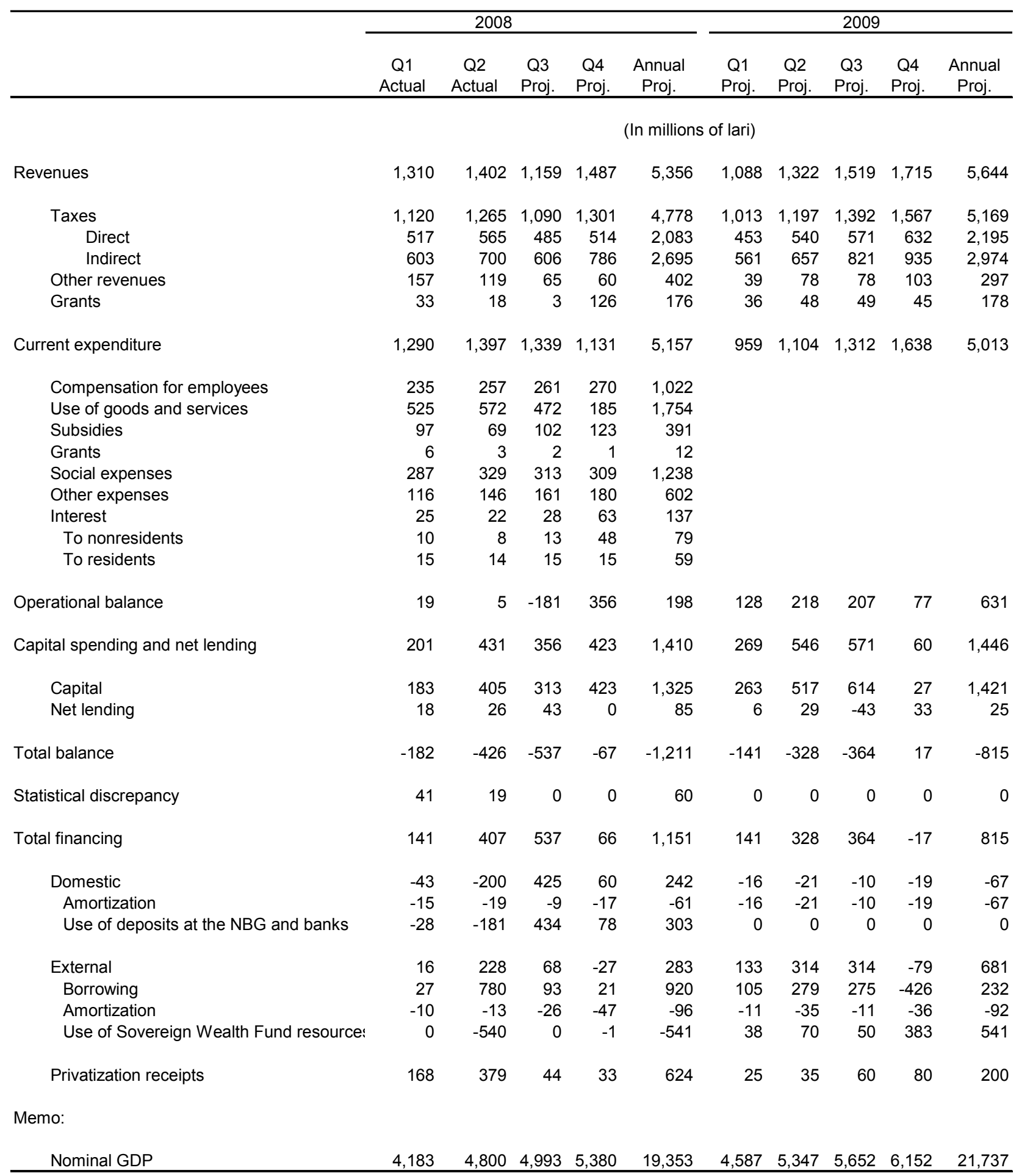

Source: Ministry of Finance; and Fund staff estimates.

1/ Consolidated government includes central and local governments and the Sovereign Wealth Funds. 
Table 4. Georgia: Summary Balance of Payments, 2006-12

(In millions of U.S. dollars)

\begin{tabular}{|c|c|c|c|c|c|c|c|c|c|c|c|}
\hline & \multirow{2}{*}{$\begin{array}{r}2006 \\
\text { Act. }\end{array}$} & \multirow{2}{*}{$\begin{array}{r}2007 \\
\text { Act. }\end{array}$} & \multirow{2}{*}{$\begin{array}{c}2008 \\
\text { Proj. }\end{array}$} & \multirow{2}{*}{$\begin{array}{c}2009 \\
\text { Proj. }\end{array}$} & \multirow{2}{*}{$\begin{array}{l}2010 \\
\text { Proj. }\end{array}$} & \multirow{2}{*}{$\begin{array}{l}2011 \\
\text { Proj. }\end{array}$} & \multirow{2}{*}{$\begin{array}{l}2012 \\
\text { Proj. }\end{array}$} & \multicolumn{2}{|c|}{2008} & \multicolumn{2}{|c|}{2009} \\
\hline & & & & & & & & $\mathrm{H} 1$ & $\mathrm{H} 2$ & $\mathrm{H} 1$ & $\mathrm{H} 2$ \\
\hline Current account balance & $-1,235$ & $-2,047$ & $-2,757$ & $-2,618$ & $-2,513$ & $-2,510$ & $-2,501$ & $-1,549$ & $-1,208$ & $-1,253$ & $-1,365$ \\
\hline Trade balance & $-2,019$ & $-2,877$ & $-3,491$ & $-3,520$ & $-3,508$ & $-3,649$ & $-3,684$ & $-1,819$ & $-1,672$ & $-1,694$ & $-1,827$ \\
\hline Exports & 1,667 & 2,104 & 2,485 & 2,750 & 3,263 & 3,674 & 4,101 & 1,294 & 1,191 & 1,371 & 1,379 \\
\hline Imports & $-3,686$ & $-4,981$ & $-5,976$ & $-6,270$ & $-6,771$ & $-7,323$ & $-7,785$ & $-3,113$ & $-2,863$ & $-3,065$ & $-3,205$ \\
\hline Services and income (net) & 343 & 245 & -121 & -19 & 77 & 176 & 175 & -78 & -43 & 0 & -19 \\
\hline Transfers (net) & 441 & 585 & 855 & 921 & 919 & 963 & 1,008 & 348 & 507 & 441 & 480 \\
\hline Capital and financial account balance & 1,617 & 2,388 & 2,152 & 2,481 & 2,531 & 2,701 & 2,871 & 1,731 & 420 & 1,156 & 1,325 \\
\hline Capital account & 169 & 126 & 138 & 234 & 186 & 185 & 181 & 37 & 101 & 116 & 118 \\
\hline Financial account & 1,448 & 2,262 & 2,013 & 2,247 & 2,346 & 2,516 & 2,690 & 1,694 & 319 & 1,040 & 1,206 \\
\hline Public sector & -9 & 17 & 170 & 422 & 127 & 79 & 147 & 164 & 6 & 212 & 210 \\
\hline Portfolio investment & 0 & 0 & 130 & 370 & 0 & 0 & 0 & 130 & 0 & 185 & 185 \\
\hline Assets, investments in SWF (- increase) & 0 & 0 & -370 & 370 & 0 & 0 & 0 & -370 & 0 & 185 & 185 \\
\hline Liabilities (+ increase) & 0 & 0 & 500 & 0 & 0 & 0 & 0 & 500 & 0 & 0 & 0 \\
\hline Other investment (including to/from official creditors) & -9 & 17 & 40 & 52 & 127 & 79 & 147 & 34 & 6 & 27 & 25 \\
\hline of which: Disbursements & 109 & 101 & 115 & 92 & 181 & 138 & 202 & 48 & 68 & 47 & 45 \\
\hline of which: Debt repayments & -124 & -45 & -79 & -41 & -53 & -60 & -55 & -17 & -62 & -20 & -20 \\
\hline Private sector & 1,457 & 2,245 & 1,844 & 1,825 & 2,218 & 2,437 & 2,544 & 1,531 & 313 & 829 & 996 \\
\hline Foreign direct investment & & & & & & & & & & & \\
\hline (including privatization receipts) & 1,076 & 1,562 & 1,237 & 1,198 & 1,452 & 1,630 & 1,714 & 857 & 380 & 593 & 604 \\
\hline Other private capital (net) & & & & & & & & & & & \\
\hline (includes bank loans, portfolio) & 382 & 683 & 606 & 628 & 766 & 807 & 830 & 673 & -67 & 236 & 392 \\
\hline Errors and omissions & 58 & -24 & -43 & 0 & 0 & 0 & 0 & -43 & 0 & 0 & 0 \\
\hline Overall balance & 439 & 317 & -648 & -137 & 18 & 191 & 370 & 140 & -788 & -96 & -41 \\
\hline International reserves and exceptional financing & & & & & & & & & & & \\
\hline Gross reserves (- increase) & -439 & -379 & 131 & -485 & -196 & -129 & -92 & -125 & 256 & -241 & -244 \\
\hline Exceptional financing (incl. debt relief, rescheduling) & 7 & 60 & 3 & 0 & 0 & 0 & 0 & 3 & 0 & 0 & 0 \\
\hline Use of Fund resources & -7 & 2 & -35 & -28 & -22 & -61 & -278 & -18 & -18 & -13 & -15 \\
\hline Financing Gap & 0 & 0 & -550 & -650 & -200 & 0 & 0 & 0 & -550 & -350 & -300 \\
\hline Financing of the gap & $\ldots$ & $\ldots$ & 550 & 650 & 200 & $\ldots$ & $\ldots$ & $\ldots$ & 550 & 350 & 300 \\
\hline IMF (SBA Purchases) & $\ldots$ & $\ldots$ & 350 & 325 & 75 & $\ldots$ & $\ldots$ & $\ldots$ & 350 & 175 & 150 \\
\hline Other financing & $\cdots$ & $\begin{array}{l}\cdots \\
\ldots\end{array}$ & 200 & 325 & 125 & $\cdots$ & $\cdots$ & $\begin{array}{l}\cdots \\
\ldots\end{array}$ & 200 & 175 & 150 \\
\hline U.S. & $\begin{array}{l}\cdots \\
\cdots\end{array}$ & $\begin{array}{l}\cdots \\
\ldots\end{array}$ & 170 & $\ldots$ & $\ldots$ & $\begin{array}{l}\cdots \\
\ldots\end{array}$ & $\begin{array}{l}\cdots \\
\cdots\end{array}$ & $\begin{array}{l}\cdots \\
\cdots\end{array}$ & $\ldots$ & $\ldots$ & $\ldots$ \\
\hline World Bank & $\ldots$ & $\ldots$ & 30 & $\ldots$ & $\ldots$ & $\ldots$ & $\ldots$ & $\ldots$ & $\ldots$ & $\ldots$ & $\ldots$ \\
\hline Memorandum items: & & & & & & & & & & & \\
\hline Nominal GDP & 7,764 & 10,227 & 13,281 & 13,973 & 15,772 & 17,721 & 20,099 & & & & \\
\hline Current account deficit (percent of GDP) & 15.9 & 20.0 & 20.8 & 18.7 & 15.9 & 14.2 & 12.4 & & & & \\
\hline Trade deficit (percent of GDP) & 26.0 & 28.1 & 26.3 & 25.2 & 22.2 & 20.6 & 18.3 & & & & \\
\hline Merchandise export growth (percent) & 13.2 & 26.3 & 18.1 & 10.6 & 18.7 & 12.6 & 11.6 & & & & \\
\hline Merchandise export volume growth (percent) & 2.7 & 15.4 & 3.6 & 6.7 & 13.6 & 7.6 & 10.8 & & & & \\
\hline Merchandise import growth (percent) & 37.2 & 35.1 & 20.0 & 4.9 & 8.0 & 8.2 & 6.3 & & & & \\
\hline Merchandise import volume growth (percent) & 16.2 & 15.9 & 4.5 & 4.3 & 5.3 & 8.9 & 7.1 & & & & \\
\hline Gross international reserves (end of period) & 881 & 1,361 & 1,270 & 1,755 & 1,951 & 2,080 & 2,173 & & & & \\
\hline (in months of next year imports of goods and services) & 1.8 & 2.3 & 2.1 & 2.6 & 2.7 & 2.7 & 2.7 & & & & \\
\hline Public and publicly guaranteed external debt (nominal) & 1,697 & 1,790 & 2,790 & 3,618 & 3,797 & 3,818 & 3,689 & & & & \\
\hline (in percent of GDP) & 21.9 & 17.5 & 21.0 & 25.9 & 24.1 & 21.5 & 18.4 & & & & \\
\hline Public debt service & 198 & 143 & 181 & 181 & 190 & 234 & 445 & & & & \\
\hline (in percent of exports of goods and services) & 7.7 & 4.4 & 4.9 & 4.4 & 4.0 & 4.4 & 7.5 & & & & \\
\hline Total external debt $1 /$ & 2,328 & 3,136 & 4,600 & 5,745 & 6,229 & 6,690 & 6,980 & & & & \\
\hline (in percent of GDP) & 30.0 & 30.7 & 34.6 & 41.1 & 39.5 & 37.8 & 34.7 & & & & \\
\hline Total external debt service $1 /$ & 269 & 265 & 512 & 626 & 739 & 823 & 1,141 & & & & \\
\hline (in percent of exports of goods and services) & 10.5 & 8.2 & 14.0 & 15.3 & 15.4 & 15.4 & 19.3 & & & & \\
\hline Capital inflows to private sector (percent of GDP) & 18.8 & 22.0 & 13.9 & 13.1 & 14.1 & 13.8 & 12.7 & & & & \\
\hline
\end{tabular}

Sources: Georgian authorities; and Fund staff estimates.

1/ For private debt starting in 2008, estimates based on the survey by the National Bank of Georgia and Fund staff assumptions.

Note: The change in gross international reserves does not equal the increase in reserves because the increase in reserves does not include valuation/reclassification effects as per Balance of Payments Manual 5 . 
Table 5. Georgia: Accounts of the National Bank of Georgia, 2006-09

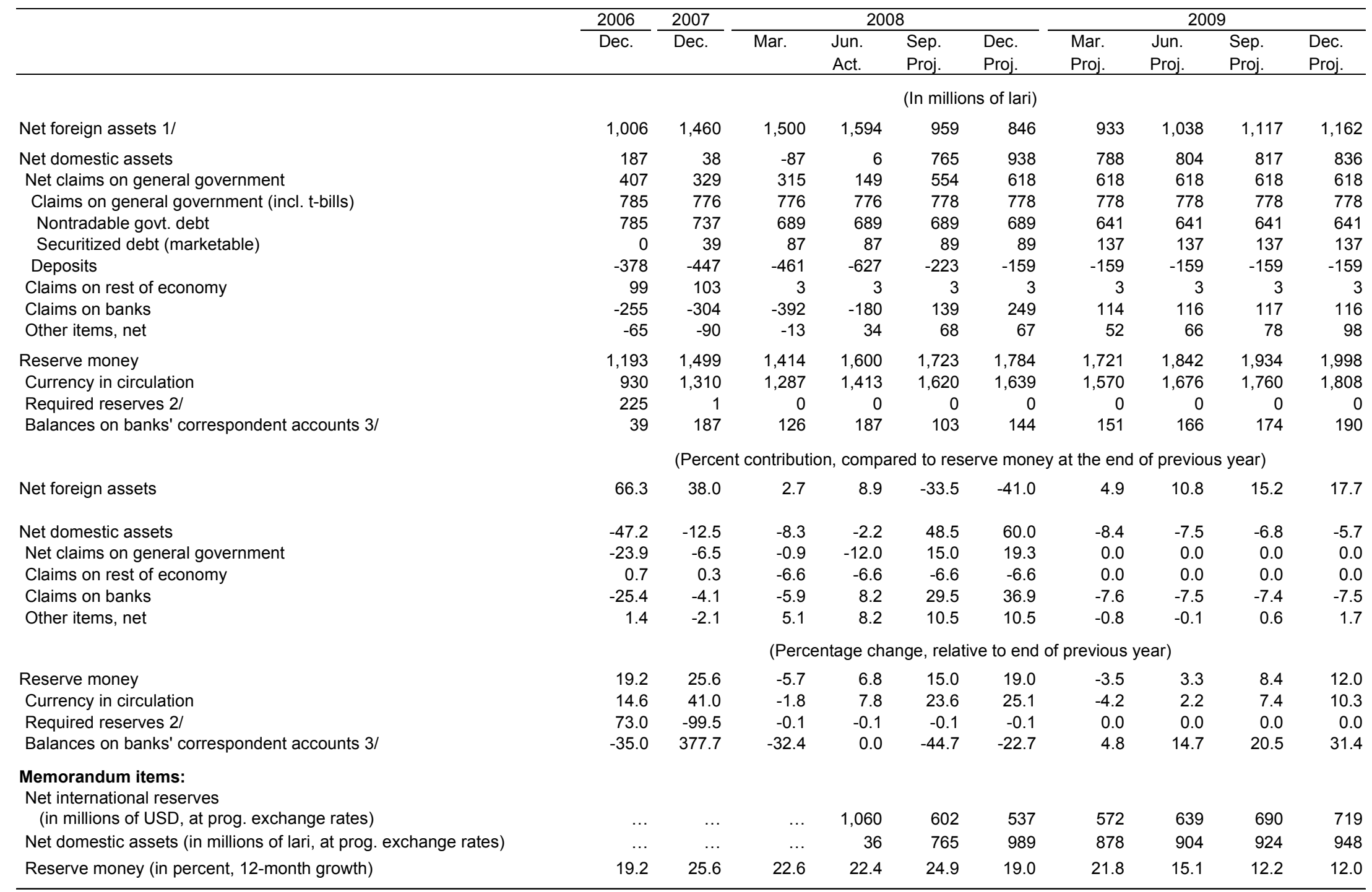

Sources: National Bank of Georgia; and Fund staff estimates.

$1 /$ New classification of gross international reserves reported since the beginning of 2007

2/ The required reserve regime was modified in May 2007. Under the new regime, tha lari reserves are deposited at banks' corresponding accounts, the foreign-currency reserves have been gradually converted into the required currency (USD) and included in net foreign assets as both asset and liability.

$3 /$ Including the lari required reserves and overnight deposits from banks. 
Table 6. Georgia: Monetary Survey, 2006-09

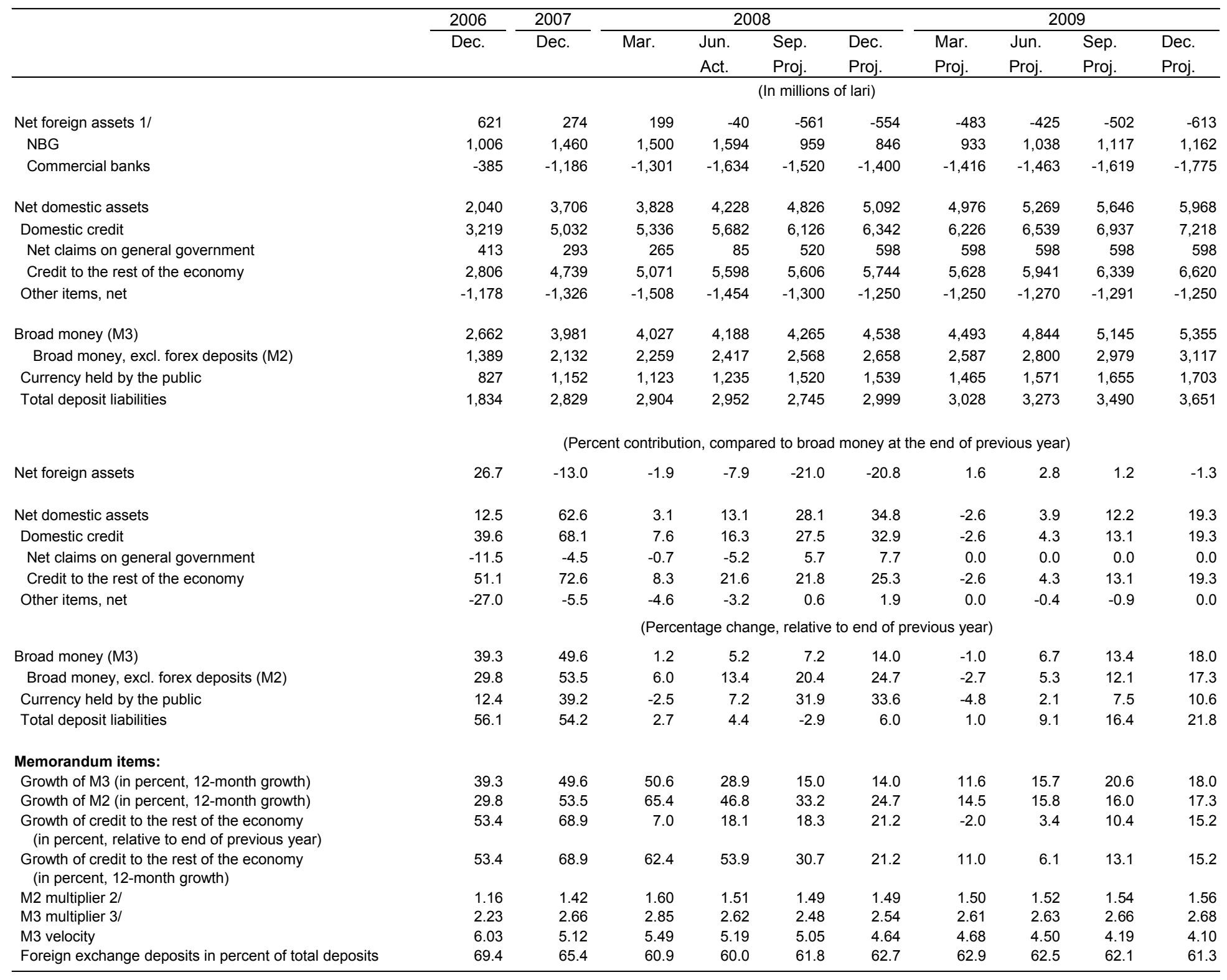

Sources: National Bank of Georgia; and Fund staff estimates.

$1 /$ New classification of gross international reserve reported since the beginning of 2007.

2/ M2 divided by reserve money.

$3 / \mathrm{M} 3$ divided by reserve money. 
Table 7. Georgia: External Vulnerability Indicators, 2006-15

\begin{tabular}{|c|c|c|c|c|c|c|c|c|c|c|}
\hline & 2006 & 2007 & $\begin{array}{l}2008 \\
\text { Proj. }\end{array}$ & $\begin{array}{c}2009 \\
\text { Proj. }\end{array}$ & $\begin{array}{l}2010 \\
\text { Proj. }\end{array}$ & $\begin{array}{c}2011 \\
\text { Proj. }\end{array}$ & $\begin{array}{c}2012 \\
\text { Proj. }\end{array}$ & $\begin{array}{c}2013 \\
\text { Proj. }\end{array}$ & $\begin{array}{c}2014 \\
\text { Proj. }\end{array}$ & $\begin{array}{c}2015 \\
\text { Proj. }\end{array}$ \\
\hline Value of exports of goods and services, percent change & 17.6 & 26.1 & 13.1 & 11.5 & 17.5 & 11.5 & 10.5 & 8.8 & 7.8 & 7.0 \\
\hline Value of imports of goods and services, percent change & 33.0 & 34.0 & 20.0 & 4.1 & 7.9 & 8.0 & 6.3 & 7.3 & 5.9 & 4.8 \\
\hline Terms of trade (deterioration - ) & -6.9 & -5.6 & -0.7 & 3.0 & 1.8 & 5.3 & 1.5 & 1.5 & 0.0 & 0.2 \\
\hline Current account balance (percent of GDP) & -15.9 & -20.0 & -20.8 & -18.7 & -15.9 & -14.2 & -12.4 & -11.8 & -10.6 & -9.7 \\
\hline Capital and financial account (percent of GDP) & 20.8 & 23.4 & 16.2 & 17.8 & 16.0 & 15.2 & 14.3 & 13.0 & 12.3 & 10.9 \\
\hline External public debt (percent of GDP) & 21.9 & 17.5 & 21.0 & 25.9 & 24.1 & 21.5 & 18.4 & 15.2 & 13.9 & 13.1 \\
\hline in percent of exports of goods and services & 66.1 & 55.3 & 76.2 & 88.6 & 79.1 & 71.4 & 62.4 & 53.3 & 50.3 & 47.9 \\
\hline \multicolumn{11}{|l|}{ Debt service on external public debt } \\
\hline (in percent of exports of goods and services) & 7.7 & 4.4 & 4.9 & 4.4 & 4.0 & 4.4 & 7.5 & 16.6 & 4.7 & 4.5 \\
\hline External debt (percent of GDP) & 30.0 & 30.7 & 34.6 & 41.1 & 39.5 & 37.8 & 34.7 & 31.5 & 29.6 & 28.9 \\
\hline in percent of exports of goods and services & 90.7 & 96.9 & 125.6 & 140.7 & 129.8 & 125.1 & 118.1 & 110.5 & 107.5 & 105.7 \\
\hline \multicolumn{11}{|l|}{ Debt service on external debt } \\
\hline (in percent of exports of goods and services) & 10.5 & 8.2 & 14.0 & 15.3 & 15.4 & 15.4 & 19.3 & 29.3 & 18.0 & 18.3 \\
\hline \multicolumn{11}{|l|}{ Gross international reserves } \\
\hline in millions of USD & 881 & 1,361 & 1,270 & 1,755 & 1,951 & 2,080 & 2,173 & 2,094 & 2,262 & 2,446 \\
\hline in months of next year's imports of goods and servces & 1.8 & 2.3 & 2.1 & 2.6 & 2.7 & 2.7 & 2.7 & 2.4 & 2.5 & 2.5 \\
\hline in percent of external debt & 37.9 & 43.4 & 27.6 & 30.5 & 31.3 & 31.1 & 31.1 & 29.5 & 30.4 & 31.2 \\
\hline in percent of short-term external debt & 491 & 549 & 454 & 669 & 874 & 818 & 761 & 676 & 716 & 721 \\
\hline
\end{tabular}

Sources: IMF Finance Department; and Fund staff estimates and projections. 
Table 8. Georgia: Indicators of Fund Credit, 2006-16

(In millions of SDR)

\begin{tabular}{|c|c|c|c|c|c|c|c|c|c|c|c|}
\hline & 2006 & 2007 & $\begin{array}{c}2008 \\
\text { Proj. }\end{array}$ & $\begin{array}{c}2009 \\
\text { Proj. }\end{array}$ & $\begin{array}{l}2010 \\
\text { Proj. }\end{array}$ & $\begin{array}{c}2011 \\
\text { Proj. }\end{array}$ & $\begin{array}{c}2012 \\
\text { Proj. }\end{array}$ & $\begin{array}{c}2013 \\
\text { Proj. }\end{array}$ & $\begin{array}{c}2014 \\
\text { Proj. }\end{array}$ & $\begin{array}{l}2015 \\
\text { Proj. }\end{array}$ & $\begin{array}{c}2016 \\
\text { Proj. }\end{array}$ \\
\hline \multicolumn{12}{|l|}{ Existing Fund credit } \\
\hline Stock 1/ & 157.1 & 159.2 & 137.1 & 119.1 & 105.0 & 87.1 & 67.2 & 47.6 & 29.4 & 14.0 & 4.2 \\
\hline Obligations & 34.2 & 26.7 & 22.8 & 18.6 & 14.7 & 18.4 & 20.3 & 19.9 & 18.4 & 15.5 & 9.8 \\
\hline \multicolumn{12}{|l|}{ Proposed SBA } \\
\hline Disbursements & $\ldots$ & $\ldots$ & 224.8 & 205.0 & 47.3 & 0.0 & 0.0 & 0.0 & 0.0 & 0.0 & 0.0 \\
\hline Stock 1/ & $\ldots$ & $\ldots$ & 224.8 & 429.8 & 477.1 & 456.9 & 303.1 & 90.7 & 5.9 & 0.0 & 0.0 \\
\hline Obligations 2/ & $\ldots$ & $\ldots$ & 2.0 & 13.5 & 20.8 & 41.7 & 172.1 & 222.0 & 87.0 & 6.0 & 0.0 \\
\hline Principal (repayments/repurchases) & $\ldots$ & $\ldots$ & 0.0 & 0.0 & 0.0 & 20.2 & 153.8 & 212.4 & 84.8 & 5.9 & 0.0 \\
\hline Charges and interest & $\ldots$ & $\ldots$ & 2.0 & 13.5 & 20.8 & 21.4 & 18.3 & 9.5 & 2.2 & 0.1 & 0.0 \\
\hline Stock of existing and prospective Fund credit $1 /$ & 157.1 & 159.2 & 361.9 & 548.9 & 582.1 & 544.0 & 370.3 & 138.3 & 35.3 & 14.0 & 4.2 \\
\hline In percent of quota & 104.5 & 105.9 & 240.8 & 365.2 & 387.3 & 361.9 & 246.4 & 92.0 & 23.5 & 9.3 & 2.8 \\
\hline In percent of GDP & 3.0 & 2.4 & 4.4 & 6.2 & 5.9 & 4.9 & 2.9 & 1.0 & 0.2 & 0.1 & 0.0 \\
\hline In percent of exports of goods and nonfactor services & 9.0 & 7.5 & 15.8 & 21.3 & 19.3 & 16.2 & 10.0 & 3.4 & 0.8 & 0.3 & 0.1 \\
\hline In percent of gross reserves & 26.2 & 17.9 & 45.7 & 49.6 & 47.5 & 41.7 & 27.2 & 10.6 & 2.5 & 0.9 & 0.3 \\
\hline \multicolumn{12}{|l|}{ Obligations to the Fund from existing and prospective } \\
\hline Fund arrangements & 34.2 & 26.7 & 24.8 & 32.1 & 35.5 & 60.0 & 192.4 & 241.8 & 105.4 & 21.5 & 9.8 \\
\hline In percent of quota & 22.8 & 17.8 & 16.5 & 21.3 & 23.6 & 39.9 & 128.0 & 160.9 & 70.1 & 14.3 & 6.5 \\
\hline In percent of GDP & 0.6 & 0.4 & 0.3 & 0.4 & 0.4 & 0.5 & 1.5 & 1.7 & 0.7 & 0.1 & 0.1 \\
\hline In percent of exports of goods and nonfactor services & 2.0 & 1.3 & 1.1 & 1.2 & 1.2 & 1.8 & 5.2 & 6.0 & 2.4 & 0.5 & 0.2 \\
\hline In percent of gross reserves & 5.7 & 3.0 & 3.1 & 2.9 & 2.9 & 4.6 & 14.1 & 18.5 & 7.5 & 1.4 & 0.6 \\
\hline
\end{tabular}

Sources: IMF Finance Department; and Fund staff estimates and projections.

1/ End of period.

2/ Repayment schedule based on repurchase obligations. 
Table 9. Georgia: External Financing Requirements and Sources, 2006-12 (In millions of U.S. dollars)

\begin{tabular}{|c|c|c|c|c|c|c|c|}
\hline & 2006 & 2007 & 2008 & 2009 & 2010 & 2011 & 2012 \\
\hline Total requirements & $-1,418$ & $-2,185$ & $-3,251$ & $-2,331$ & $-2,602$ & $-2,963$ & $-3,238$ \\
\hline Current account deficit & $-1,235$ & $-2,047$ & $-2,757$ & $-2,618$ & $-2,513$ & $-2,510$ & $-2,501$ \\
\hline Capital outflows $1 /$ & -183 & -138 & -494 & 287 & -89 & -453 & -737 \\
\hline Total sources & 1,418 & 2,185 & 2,701 & 1,680 & 2,402 & 2,963 & 3,238 \\
\hline Capital inflows & 1,808 & 2,462 & 2,567 & 2,165 & 2,598 & 3,092 & 3,331 \\
\hline Project grants & 169 & 126 & 138 & 234 & 186 & 185 & 181 \\
\hline Foreign direct investment & 1,076 & 1,562 & 1,237 & 1,198 & 1,452 & 1,630 & 1,714 \\
\hline Disbursements to public sector & 109 & 101 & 615 & 92 & 181 & 138 & 202 \\
\hline Private sector net inflows $2 /$ & 455 & 672 & 577 & 641 & 779 & 1,139 & 1,234 \\
\hline Financing (incl. exceptional) & 48 & 102 & 3 & 0 & 0 & 0 & 0 \\
\hline IMF (PRGF) & 41 & 42 & 0 & 0 & 0 & 0 & 0 \\
\hline Change in arrears, net (- decrease) & -69 & -27 & -1 & 0 & 0 & 0 & 0 \\
\hline Debt rescheduling, pre-payment (net) $3 /$ & 76 & 87 & 3 & 0 & 0 & 0 & 0 \\
\hline Change in reserves (- increase) & -439 & -379 & 131 & -485 & -196 & -129 & -92 \\
\hline Financing gap & 0 & 0 & -550 & -650 & -200 & 0 & 0 \\
\hline Financing of the gap & $\cdots$ & $\ldots$ & 550 & 650 & 200 & $\ldots$ & $\ldots$ \\
\hline of which: IMF (SBA) & $\ldots$ & $\ldots$ & 350 & 325 & 75 & $\ldots$ & $\cdots$ \\
\hline \multicolumn{8}{|l|}{ Memorandum items (in percent of GDP): } \\
\hline Total financing requirements & -18.3 & -21.4 & -24.5 & -16.7 & -16.5 & -16.7 & -16.1 \\
\hline Total sources & 18.3 & 21.4 & 20.3 & 12.0 & 15.2 & 16.7 & 16.1 \\
\hline Capital inflows & 23.3 & 24.1 & 19.3 & 15.5 & 16.5 & 17.5 & 16.6 \\
\hline Exceptional financing & 0.6 & 1.0 & 0.0 & 0.0 & 0.0 & 0.0 & 0.0 \\
\hline Change in reserves (- increase) & -5.6 & -3.7 & 1.0 & -3.5 & -1.2 & -0.7 & -0.5 \\
\hline
\end{tabular}

Sources: Georgian Statistics Department; National Bank of Georgia; and Fund staff estimates.

$1 /$ Including scheduled public sector amortization and principal payments to the IMF.

2/ Includes errors and omissions.

3/ Assumes rescheduling of 2003 arrears in 2004 and of principal maturities falling due during 2004-06. Includes comparable treatment by non-Paris Club bilateral creditors. 
Table 10. Georgia: Prudential Indicators of Commercial Banks, 2004-08

\begin{tabular}{|c|c|c|c|c|c|c|}
\hline & \multirow[t]{2}{*}{2004} & \multirow[t]{2}{*}{2005} & \multirow{2}{*}{2006} & \multirow{2}{*}{2007.} & \multicolumn{2}{|c|}{2008} \\
\hline & & & & & Mar. & Jun. \\
\hline Capital adequacy ratio (in percent) & 18.8 & 17.5 & 20.6 & 16.0 & 15.6 & 15.7 \\
\hline Leverage ratio1/ & 27.9 & 25.9 & 30.7 & 25.9 & 26.7 & 24.8 \\
\hline Nonperforming loans (in percent of total loans) & 6.2 & 3.8 & 2.5 & 2.6 & 3.0 & 3.4 \\
\hline Specific provisions (in percent of total loans) & 4.3 & 2.4 & 1.7 & 1.7 & 1.9 & 2.2 \\
\hline Loans collateralized by real estate (in percent of total loans) & 33.5 & 30.8 & 31.1 & 43.8 & 43.6 & 40.5 \\
\hline Loans in foreign exchange (in percent of total loans) & 86.7 & 76.2 & 73.8 & 68.6 & 65.9 & 64.9 \\
\hline Net foreign assets (in millions of lari) & 54.6 & -231.5 & -385.1 & -1276.0 & -1394.5 & -1742.4 \\
\hline Net foreign assets (in percent of total assets) & 3.2 & -9.1 & -9.1 & -17.7 & -17.2 & -20.2 \\
\hline Net open foreign exchange position $2 /$ & 7.4 & 7.5 & 3.7 & 5.0 & 3.5 & 1.5 \\
\hline Liquidity ratio (in percent) & 45.0 & 33.3 & 41.5 & 37.2 & 36.8 & 33.3 \\
\hline
\end{tabular}

Source: National Bank of Georgia.

1/ Defined as the ratio of total capital to total liabilities; an increase in the ratio indicates an improvement. 2/ Percent of Total Regulatory Capital. 
Table 11. Georgia: Review and Disbursements Under the 18-Month SBA

\begin{tabular}{|c|c|c|}
\hline Date & Action & $\begin{array}{l}\text { Associated Disbursements } \\
\text { (in millions of SDR) }\end{array}$ \\
\hline On or after September 15, 2008 & Approved 18-month arrangement & 161.7 \\
\hline After November 15, 2008 & Completed first review based on end-September performance criteria & 63.1 \\
\hline After February 15, 2009 & Completed second review based on end-December performance criteria & 63.1 \\
\hline After May 15, 2009 & Completed third review based on end-March performance criteria & 47.3 \\
\hline After August 15, 2009 & Completed fourth review based on end-June performance criteria & 47.3 \\
\hline After November 15, 2009 & Completed fifth review based on end-September performance criteria & 47.3 \\
\hline After February 15, 2010 & Completed sixth review based on end-December performance criteria & 47.3 \\
\hline Total & & 477.1 \\
\hline
\end{tabular}

Source: Fund staff. 


\section{ATTACHMENT I. GEORGIA: LETTER OF INTENT}

September 9, 2008

Mr. Dominique Strauss-Kahn

Managing Director

International Monetary Fund

Washington, D.C.

Dear Mr. Strauss-Kahn:

In the five years since the Rose Revolution, Georgia's macroeconomic management and cooperation with the International Monetary Fund (IMF) have been excellent. In mid-2004, the IMF approved a Poverty Reduction and Growth Facility (PRGF) arrangement to support a wide range of the economic reforms. The three-year PRGF arrangement, which was completed successfully in September 2007, laid the foundation for our recent strong growth and moderate inflation.

This year, tensions with Russia over the two breakaway regions of Georgia intensified and, in August, culminated in a conflict with Russia. A ceasefire agreement was signed on August 16 and Russian troops began withdrawing on August 22. In addition to the loss of life, systematic destruction of our military infrastructure and damage to personal property, economic activity was disrupted and Georgia's civilian infrastructure was seriously damaged.

Perhaps most damaging to Georgia's near-term growth prospects was the erosion of investor confidence. The government of Georgia is confident that the economy will recover from the conflict as we succeed in sustaining investor confidence. Therefore, it is of the utmost importance that measures be implemented that will reassure both the domestic and foreign business community as soon as possible.

The attached Memorandum of Economic and Financial Policies (MEFP) describes our economic policies and strategies for the next 18 months, which we understand will form the basis for continued IMF support. On the basis of the policies and the specific targets for the next year described herein, and due to the extraordinary external financing requirement created by the conflict with Russia, we hereby request a Stand-By Arrangement for the period of September 2008 to March 2010 in the amount of SDR 477.1 million (approximately $\$ 750$ million), equivalent to 317.4 percent of quota.

The government believes that the policies set forth in the MEFP are adequate to achieve the objectives of the program, but it is prepared to consider taking other measures that may become appropriate for this purpose, in consultation with the Fund. During the period of the arrangement, the authorities of Georgia will maintain the usual close policy dialogue with the 
Fund, assisted by the continued presence of a resident representative should the IMF decide to maintain the post open.

Sincerely yours,

/s/

Lado Gurgenidze

Prime Minister of Georgia /s/

Nika Gilauri

Minister of Finance /s/

David Amaglobeli

Acting President 


\section{AtTaChment II. Georgia: Memorandum of Economic and FinanCial Policies for 2008 AND 2009}

This memorandum sets out the economic and financial policies of the Georgian government for September 2008-December 2009. These policies are the basis for the 18-month IMF-supported Stand-By Arrangement (SBA).

\section{A. Recent Economic Developments}

1. Since 2004, we have implemented a policy of comprehensive and exemplary economic reform. At the heart of our reform effort is a commitment to foster economic growth through private sector investment. To this end, we have eliminated barriers to private sector activity by aggressively deregulating the economy, privatizing most state assets, reducing and simplifying taxes, dramatically liberalizing the trade regime, investing in infrastructure, and significantly reducing bureaucratic barriers and as a result reducing corruption. In 2007, we were the leading economic reformer in the world. Our standing in the World Bank and IFC survey of business environments ("Doing Business") jumped from $137^{\text {th }}$ place in 2004 to $18^{\text {th }}$ in 2008 .

2. The macroeconomic results of our efforts have been inspirational and significant. Growth of GDP averaged 8.3 percent during 2004-06, was 12.4 percent last year and 9.3 percent in the first quarter of this year. In large part, Georgia's extraordinary economic performance has been driven by private capital inflows. In 2004, these inflows were only $\$ 0.5$ billion. By 2007, private capital inflows had increased to $\$ 2.3$ billion, which is $22 \frac{1}{2}$ percent of GDP. Further, FDI inflows come from geographically diverse sources and the breadth of international institutional investors investing in Georgia - over 300 - is unusual for such a small country. In April 2008, Georgia successfully issued its first sovereign Eurobond, raising $\$ 500$ million in an offer that was heavily oversubscribed.

3. Against a background of rapid economic growth, inflationary pressures are inevitable. In mid-2006, 12-month inflation exceeded 14 percent. Recognizing the social damage of inflation as well as its contribution to macroeconomic instability, we intensified efforts to return to single-digit inflation. Our efforts have been greatly complicated by the global environment of high energy and food prices. Nonetheless, the combination of fiscal and monetary restraint has succeeded in reducing 12-month inflation to 9.8 percent as of end-July this year.

4. On balance, our macroeconomic performance has indeed been impressive. We believe that this record of growth and stability can be continued in the future. In order to overcome the dire consequences of our recent conflict with Russia, we must redouble our efforts to improve macroeconomic conditions and reassure investors that Georgia will continue to be an attractive place for business. 


\section{Fiscal performance}

5. A key indicator of Georgia's economic success is our greatly improved revenue performance that has allowed us to modernize the state and civil service, enhance the social safety net and invest in infrastructure. In 2003, tax revenues (including social contributions) accounted for only 14.6 percent of GDP. By 2007, tax revenues accounted for 25.8 percent of GDP. This achievement was the result of greatly improved tax administration, a simplified tax code and procedures, better taxpayer services and infrastructure, and, most important, fewer taxes and lower rates.

6. In July 2008, parliament approved legislation stipulating that state budget expenditures should not exceed 29 percent of GDP in 2009 (compared with our budget estimate of 30.3 percent for this year), should decline to 25 percent of GDP by 2011, and remain at or below this level thereafter. Additionally, parliament approved further liberalization of the tax regime and the establishment of two sovereign wealth funds - the Stabilization Fund and the Future Generations Fund - as a means of sheltering surplus revenues.

7. During the first half of 2008, revenue collection exceeded our projections by 2.6 percent and increased by 31.3 percent compared with the same period last year. In the first six months of 2008, privatization proceeds were $\$ 352$ million, exceeding the forecast by 68 percent and exceeding substantially the proceeds in any previous calendar year. At the same time, expenditures have been higher than projected because of the need for greater defense spending, which was originally projected to decline as a share of GDP this year. Capital expenditures, as well as social and other expenditures, were in line with targets for the first half of the year. The major part of the Eurobond proceeds were transferred to the Future Generations and the Stabilization Funds. Thus, the effect of these proceeds on the consolidated budget deficit was neutral.

\section{Monetary policy}

8. In March 2008, parliament approved amendments to the law governing the National Bank of Georgia (NBG), which make price stability the primary objective of the NBG. Financial stability and support for sustainable economic growth are secondary objectives. The new law also requires the NBG to target single-digit inflation. If this inflation target is not met (with a 2-percentage-point margin of error), then certain sanctions, including possible dismissal of the president of the NBG, are imposed. Moreover, under the new law, banking supervision was separated from the NBG and a unified Financial Supervision Agency was created. The board of the NBG will be downsized from nine to five members and the Monetary Policy Committee was created as the key decision-making body on monetary policy issues. 
9. The legislative changes approved by parliament reflect a broad consensus within Georgia that inflation must be controlled. From November 2007 through July 2008, the NBG had been tightening monetary policy. The NBG's main policy rate was introduced and that rate was raised by 500 bps from November 2007 through July 2008. The NBG's certificates of deposits (CDs) and government notes have been used to conduct open market operations. As a result of the development of the interbank lending market due to prior changes in the reserve requirements regulation, the NBG started daily calculation and publication of Tbilisi Interbank Rates (TIBR) for overnight and up to seven-day loans.

10. As a result of these measures, reserve money growth was limited to 21 percent in the 12 months to mid-August 2008, while broad money growth was 28 percent as of end-July 2008. These compare favorably with the figures for end-March 2008 of 22 percent and 51 percent, respectively. While the growth of bank credit was high (55 percent in the 12 months to end-July 2008), it has slowed significantly this year and was only 23 percent in the first seven months of this year.

11. Since late 2007, the NBG has allowed much greater flexibility in exchange rates. For the first seven months of 2007, the nominal exchange rate of the lari against the U.S. dollar appreciated by 3 percent, while in the first seven months of 2008, the nominal appreciation was nearly 13 percent. This policy shift has allowed the NBG to intervene less frequently and subsequently made a significant contribution to our ability to reduce inflation.

12. As the economy has modernized and re-industrialized with the support of large capital inflows, the current account deficit has increased. In 2007, the current account deficit was $\$ 2.0$ billion or about 20 percent of GDP. In the first half of 2008 , we estimate the deficit was about $\$ 1.5$ billion. In large part, the current account deficit has been self-financing, since about 60 percent of capital inflows is for import financing. Over the past four years, we have seen a significant diversification of exports and average annual growth of 26 percent (200307). To aid export growth, we have negotiated a free-trade agreement with Turkey (which is awaiting ratification by Turkey), requested a free-trade agreement with the U.S., and are benefiting from GSP+ with the EU.

\section{Structural reform}

13. In addition to the foregoing reforms, we have given especial emphasis to structural reform as a means of fostering competitiveness and growth.

14. In order to improve the quality of financial sector regulation, we created the Financial Supervision Agency (FSA). The FSA is a fully independent agency with its own supervisory board. The FSA is currently in the process of implementing a system of consolidated supervision of banks, insurance companies and securities firms. 
15. An early activity of the FSA was to strengthen and refine our AML/CFT legislation. The relevant legislation was approved by parliament in March this year. In July, MONEYVAL completed its biannual review of Georgia and fully endorsed our AML/CFT legislation framework. We have also modified our banking laws with respect to fit and proper requirements for managers and owners. As a result, we no longer take a relatively simplistic approach of assessing the nominal owners and, in addition, identify and assess the actual beneficial owners of the institutions.

16. In an effort to increase the professionalism and efficiency of the NBG, we recently restructured and downsized the central bank. Since October 2007, total staff at the NBG has been decreased by 350 or about 56 percent. We believe that a more professional central bank will enhance our ability to achieve our main policy objectives and boost public confidence. These measures will also contribute to macroeconomic stability and long-term sustainable economic growth of the Georgian economy.

17. In addition, we have implemented numerous other structural reforms that are vital to economic growth, including deregulating the natural gas market; streamlining securities regulation; demutualizing the stock exchange; removing operational constraints in and facilitating entry into financial markets; liberalizing the issuance of building permits; simplifying export and import procedures; passage of a new law on insolvency and new foreclosure procedures; further simplifying business registration procedures; and introducing a comprehensive healthcare sector reform that entails full privatization of health care provision facilities and provides health care insurance for low-income groups.

\section{B. Economic Policies Going Forward}

18. Georgia is committed to enhancing macroeconomic stability and fostering economic growth through private sector investment. While we recognize the critical role of the public sector, especially in the realm of improving conditions for vulnerable groups, we believe that economic growth can only be led by the private sector. Hence, our emphasis is on creating an environment that is highly conducive to private sector growth. At the same time, we aim to improve the quality of government services whilst limiting the overall size of public expenditures.

19. The macroeconomic outlook has deteriorated sharply as a result of the conflict.

- $\quad$ Prior to the conflict, we were projecting continued high real GDP growth (about 9 percent) in 2008 and lower inflation of 8 percent by the end of the year. The medium-term prospects were strong. While we believe we may still be able to maintain our 2008 inflation objective, the expected sharp slowdown in private inflows (from $\$ 1.5$ billion in the first half of the year to $\$ 0.5$ billion in the second half) would lead to lower real economic growth (now projected at only $3 \frac{1}{2}$ percent). 
- $\quad$ Private inflows are anticipated to pick up modestly in 2009 (to $\$ 1.7$ billion), which could support real GDP growth of 4 percent. Inflation would remain in single digits but the narrowing of the external current account deficit is not expected to be commensurate with the slowing of economic growth, reflecting the impact of higher imports for reconstruction, and high import prices.

- In the medium term, inflows are expected to recover and sustain higher investment, while export growth is expected to increase gradually. As a result, real GDP growth is projected to recover to mid single digits, while inflation would decline gradually.

- Under this scenario, in the absence of increased international support, Georgia's international reserves would decline sharply over the remainder of this year and next, to a level that would cover just a few weeks of imports. This would substantially weaken Georgia's external position. Strong international support will therefore be essential to allow the maintenance of an adequate level of reserves, covering $23 / 4$ months of imports by end-2009. The financing gap of about $\$ 1.2$ billion over the 2008-09 period is expected to be covered by the IMF SBA and by grants and concessional financing provided by other IFIs and bilateral donors and creditors.

\section{Fiscal policy}

20. Consistent with the legislative changes approved by parliament this year, we are committed to minimizing the size of the fiscal footprint on the economy, ensuring fiscal prudence and preventing the underlying fiscal stance from contributing to inflationary pressures. Nonetheless, we are committed to rebuilding the infrastructure damaged by the conflict, which will require an increase in reconstruction-related spending. Given that we expect that much of this spending will be financed by donor grants, we feel that it can be accommodated within a sound macroeconomic framework that would help spur domestic demand while maintaining price stability. While some temporary increase in the fiscal deficit is inevitable during 2008 and 2009, we are determined to return to our medium term strategy of containing our fiscal footprint fiscal as soon as feasible.

21. For 2008, we will endeavor to delay all nonessential expenditures and will ensure that the overall fiscal deficit as defined in the attached Technical Memorandum of Understanding (TMU) is less than 6 percent of GDP (subject to quarterly performance criteria for end-September and end-December). This overall deficit includes the initial reconstruction spending that will be carried out in 2008. It will be subject to an upward adjustor of at most 2 percent of GDP, in the event that concessional donor financing exceeds currently declared commitments.

22. The government will submit to parliament a state budget for 2009 that will target a fiscal deficit of no more than $3 \frac{3}{4}$ percent of projected GDP, with an upward adjustor of no 
more than 3 percent of GDP in the event that concessional donor financing exceeds currently declared commitments (structural benchmark for end-December 2008).

23. In addition to implementing the legally required tax rate reductions, we will not introduce any new taxes, duties or fees, or increase any tax rates in 2009.

24. We will submit to parliament legislation to upgrade the Budget System Law (BSL) to an organic law (structural performance criterion for end-June 2009). Further, we will ensure that direct purchases of civilian good and services will not be more than 15 percent of overall approved expenditures for each state agency.

25. We will limit the contracting of public and publicly-guaranteed non-concessional external debt to no more than \$250 million during the remainder of 2008 and \$250 million during the first half of 2009 (subject to quarterly performance criteria). Additionally, during 2009, we will not increase public and publicly guaranteed domestic debt by more than GEL 100 million.

26. The Basic Data and Directions (BDD) document is being developed so that it sets out with greater clarity the government's medium-term fiscal and public expenditure strategies and plans. The quality of the BDD analysis will be improved and extended to include realistic resource ceilings for subsequent detailed budget planning. The BDD will also be disseminated more widely. The Ministry of Finance of Georgia will ensure that medium-term action plans are extended to include all spending agencies and will include clear statements of strategic directions (goals) and performance indicators (performance indicators will be developed for at least three ministries in 2010), as well as detailed costing. We will continue to improve the budget process and format, consistent with the findings of the World Bank and European Commission Public Expenditure Framework Assessment (PEFA).

27. The processing of financial transactions is being improved, with the Treasury Single Account (TSA) established and most revenues and expenditures flowing through a single process. During 2009, we will consolidate foreign currency deposits into a singe account at the NBG and make progress towards implementation of a modern E-Treasury system.

28. In 2007, the Revenue Service of the Ministry of Finance of Georgia (RS) was formed and began developing risk based customs control and tax audit systems. In 2009, the RS will finish the implementation of the risk management system and will initiate risk assessment based tax audits. For the full implementation of risk-based custom controls, a post-clearance system needs to be introduced. This requires amendments to the Customs Code, which we will submit to parliament by June 2009 in conjunction with modernization of the Tax Code.

29. The RS will continue to give priority to improving taxpayer services. The MoF will ensure that the e-filing system is developed further and captures all types of taxes by 2009 . Additional effort will be made to develop electronic systems in tax administration (e.g. e-lean 
system), in order to increase the efficiency in tax arrears collection. We will seek to receive, in 2008 Q4, technical assistance and consultancy services to prepare for the transition by 2012 to the self-assessment regime with regard to personal income tax, delivering a seamless online and offline service to tax resident individuals regardless of their location.

30. Over the past two years, the tax disputes internal resolution system proved its effectiveness, but rising number of tax disputes (reflecting increased taxpayer confidence in the MoF dispute resolution committee) need to be addressed. The MoF will finish the necessary structural reforms in 2009, which will establish an independent dispute resolution office within the MoF, and a hearing system.

31. To increase transparency, from 2009 the Ministry of Finance will produce annual reports on (i) consolidated (including government, LEPLs, and state-owned enterprises) public expenditures and (ii) public arrears and debt. The government of Georgia will ensure the information on revenues/expenditures of the public services providing LEPLs is transparent and is provided in the state budget.

\section{Monetary policy}

32. We are strongly committed to low inflation and, in the current environment, believe that maintaining single-digit inflation and reducing it gradually in the medium term is essential. To aid with our efforts to meet inflation targets, we plan to adopt an inflationtargeting regime during 2009. Although we realize that there are certain constraints in implementing full-fledged inflation targeting immediately, we believe our efforts will be successful in ensuring low and stable inflation in the medium term. In the immediate future, our monetary policy will be guided by quarterly targets (performance criteria) for the net international reserves and net domestic assets of the National Bank of Georgia, as set out in the TMU.

33. We are concerned about the impact on bank liquidity of the loss of confidence resulting from the conflict. In the wake of the conflict, the NBG waived the reserve requirements on a temporary basis, and activated an uncollateralized lending facility. To help preserve financial stability and ensure a smooth functioning of the payments system, we intend to enhance our instruments for liquidity management.

34. Now that the immediate emergency is over, we will develop and publish a liquidity management framework that outlines the objectives of liquidity management, describes the instruments, and assigns the instruments to these objectives (structural benchmark for endMarch 2009). This framework, which would also facilitate the implementation of the inflation-targeting regime, will inter alia (i) provide a clearer planning horizon for banks by enforcing the reserve requirement while adjusting the rate to the liquidity needs of the system and (ii) introduce a refinancing mechanism as the main liquidity providing instrument at interest rates determined by the market . 
35. We will also revise the NBG lender of last resort (LOLR) facility to ensure that the availability of LOLR would not encourage excessive risk-taking by financial institutions. To minimize moral-hazard concerns, it is the NBG's policy to provide LOLR only to those institutions that are judged by the FSA to be solvent. We will also be more specific about the limits and size of the LOLR facility. The revised LOLR framework will be finalized by endDecember 2008 (structural performance criterion).

36. We are fully committed to a flexible exchange rate policy. During the crisismanagement period, the NBG defended the lari to prevent further uneasiness in the market. Under the SBA, a first drawing would serve to replenish reserves. Under the program, priority will be given to maintaining the targeted level of international reserves, and the exchange rate will be allowed to adjust to a shortfall in foreign inflows in the remainder of 2008 and 2009.

37. We plan to continue building a modern central bank. To this end, we plan to strengthen our human resource management practices, introduce a new payments system for commercial banks and the treasury, automate our banknote processing system, build a new cash center, introduce new investment management and accounting software, strengthen cooperation with partner central banks, and start participation in the World Bank RAMP project.

\section{Structural reforms}

38. We recognize the importance of continued structural reform as a means of enhancing competitiveness and fostering economic growth. Our goal is to remain among the world's top economic reformers by pursuing vigorous free-market structural reform consistent with the Anglo-Saxon economic model.

39. We will continue our policy of aggressively privatizing state-owned assets. By the end of 2009, we intend to privatize at least two-thirds of the shares of the Georgian State Electricity Company; at least 24 percent of Poti Sea Port; Georgian Post; about 100,000 hectares of agricultural land; several regional airports; and numerous other state-owned assets.

40. In order to maintain the competitiveness of the Georgian economy and to encourage further capital inflows, we will avoid introducing any laws or regulations that may reduce labor market flexibility, including the labor code. Additionally, in order to address the structural labor market shortages with regard to certain categories of professionals and to enhance Georgia's appeal as a tourism and retirement destination, we will further liberalize our migration and employment policy.

41. Regarding the financial sector, we are especially pleased with the overall stability and resilience the sector has demonstrated during the recent conflict. The NBG and FSA worked 
well together to ensure the smooth operation of the payments system, as well as maintain public confidence in the lari and the banks. The FSA has started to assess any potential vulnerabilities in the banking sector emerging after the conflict by conducting on-site inspections. It is evaluating banks' liquidity positions and loan portfolios, looking into the situation of the main borrowers. Next, the FSA will make sure that the banks have contingency plans readily available to mitigate potential liquidity and capital pressures in the near future.

42. We recognize the need to strengthen further the cooperation between the FSA and the NBG. Accordingly, these two institutions will sign and implement a memorandum of understanding (structural benchmark for end-October 2008). This memorandum will define the areas of cooperation and accountability between the two institutions, containing inter alia practical and legal arrangements for information exchange on individual institutions' data, specific requirements to share promptly any possible irregularities in the financial system, and opportunities to review newly planned regulations before they are enacted.

43. Further, to strengthen the independence of the FSA and NBG, we will appoint the remaining members to the FSA board by end-June 2009 (structural benchmark for end-June 2009) and restructure the NBG board by end-2009. Additionally, we will submit to parliament during the fourth quarter of 2008 a Financial Code that will unify and consolidate banking, insurance, and securities regulation while avoiding any additional regulatory burden on financial institutions that is not envisaged in the recently passed legislation.

44. We will continue to build capacity at the FSA to adopt modern practices of risk-based supervision on a consolidated basis. We would welcome a streamlined and focused Financial Sector Assessment Program (FSAP) update mission in the second half of 2009 to assess developments in the financial sector and review the new regulatory framework.

45. In order to avoid an unnecessary regulatory burden on enterprises operating in Georgia, in the aftermath of the conflict with Russia we will avoid any amendments to or new legislation or regulation in the areas of anti-trust policy and consumer protection, as we believe any such measures would be meaningless for a small open economy like Georgia.

46. Among the other structural reforms we plan to introduce in the near future are a modern regulatory framework for water utilities; further energy sector deregulation; modernizing regulations for the use of forests and mineral resources; and implementing a merit based civil service reform. Of particular importance is our commitment to continue healthcare reform, including the completion of hospital and financing reform, licensing medical professionals and education, and reduce regulatory barriers to the entry of pharmaceuticals.

47. We will introduce a new draft Law on Statistics to parliament by year-end 2008, with the aim of creating a modern and independent statistical service that is able to deliver 
relevant and high quality statistics. An supervisory board will be established, including independent board members, and an advisory panel will be set up to oversee improvements in methodology and effectiveness.

\section{Program Monitoring}

48. The program will be subject to quarterly reviews, and quarterly performance criteria as set out in the TMU. Completion of the first two reviews under the SBA, scheduled for November 2008 and February 2009, will require observance of the quantitative performance criteria for end-September and end-December 2008 in Table 1 and the structural performance criteria for end-December 2008 shown in Table 2.

49. We authorize the IMF to publish the Letter of Intent and its attachments, and the related staff report. 
Table 1. Georgia: Quantitative Performance Criteria and Indicative Targets, 2008-09

\begin{tabular}{|c|c|c|c|c|c|}
\hline & \multirow[b]{2}{*}{ Jun-08 } & \multicolumn{2}{|c|}{ Cumulative Change from End-June 2008} & \multicolumn{2}{|c|}{ Cumulative Change from End-December 2008} \\
\hline & & $\begin{array}{c}\text { Sep-08 } \\
\text { Performance Criteria } \\
\end{array}$ & $\begin{array}{c}\text { Dec-08 } \\
\text { Performance Criteria }\end{array}$ & $\begin{array}{c}\text { Mar-09 } \\
\text { Indicative targets }\end{array}$ & $\begin{array}{c}\text { Jun-09 } \\
\text { Indicative targets }\end{array}$ \\
\hline & Actual /2 & Prog. & Prog. & Prog. & Prog. \\
\hline & \multicolumn{5}{|c|}{ (In millions of lari) } \\
\hline \multirow[t]{2}{*}{ Ceiling on cash deficit of the consolidated government } & $\ldots$ & 537 & 603 & 141 & 469 \\
\hline & \multicolumn{5}{|c|}{ (In millions of U.S. dollars) } \\
\hline \multirow{3}{*}{$\begin{array}{l}\text { Ceiling on contracting or guaranteeing of new nonconcessional } \\
\text { external debt by the public sector }\end{array}$} & $\ldots$ & 0 & 250 & 250 & 250 \\
\hline & \multicolumn{5}{|c|}{ Stocks at the end of the period } \\
\hline & \multicolumn{5}{|c|}{ (In millions of lari) } \\
\hline \multirow[t]{2}{*}{ Ceiling on net domestic assets (NDA) of the NBG 1/ } & 36 & 765 & 989 & 878 & 904 \\
\hline & \multicolumn{5}{|c|}{ (In millions of U.S. dollars) } \\
\hline Floor on net international reserves (NIR) of the NBG 1/ & 1,060 & 602 & 537 & 572 & 639 \\
\hline Ceiling on accumulation of external arrears $2 /$ & 0 & 0 & 0 & 0 & 0 \\
\hline
\end{tabular}

Sources: Georgian authorities; and Fund staff estimates.

1/ Actual figures for June 2008 and quantitative targets are based on program exchange rates.

$2 /$ The continuous performance criterion for external arrears is defined in paragraph 14 of the TMU. 
Table 2: Structural Benchmarks and Performance Criteria

Action

Timing

FSA and NBG to sign and implement a memorandum of understanding to

End-October 2008

strengthen cooperation.

NBG to introduce revised LOLR facility (structural performance criterion).

End-December 2008

Submission to parliament of a state budget for 2009 with an overall fiscal

End-December 2008

deficit of no more than $3 \frac{3}{4}$ percent of projected GDP (subject to an adjustor of

at most 3 percent of GDP as set out in the TMU).

NBG to develop and publish a liquidity management framework, including the

End-March 2009

introduction of a refinancing mechanism as the main instrument to provide

liquidity.

Appointment of the remaining members to the FSA board.

End-June 2009

Submission to parliament of a law to upgrade the Budget System Law to an

End-June 2009 organic law (structural performance criterion). 


\section{AtTachment III. GeOrgia: Technical Memorandum of Understanding (TMU)}

September 9, 2008

1. This memorandum sets out the understandings between the Georgian authorities and the IMF staff regarding the definitions of quantitative and structural performance criteria and indicative targets, as well as respective reporting requirements for the Stand-By Arrangement (SBA). These performance criteria and indicative targets are reported in Tables 1 and 2 of the Memorandum of Economic and Financial Policies (MEFP), attached to the letter dated September 9, 2008.

2. The exchange rate for the purposes of the program of the Georgian lari to the U.S. dollar is set at GEL $1.41=\$ 1$. The corresponding cross exchange rates are provided in Table 1.

\section{Consolidated Government and the Public Sector}

3. Definition: The consolidated government is defined as the central government, local governments, extrabudgetary funds, public services providing general government system LEPLs, and the Sovereign Wealth Funds (Future Generations and Stable Development Funds). In case the government establishes extrabudgetary funds, they will be consolidated within the consolidated government. The public sector consists of the consolidated government and the National Bank of Georgia (NBG).

4. Supporting material: The Treasury Department of the Ministry of Finance (MOF) will provide to the IMF detailed information on monthly revenues, expenditures, and arrears of the consolidated government. In addition, data will be provided on the cash balances in the accounts of the Ministry of Finance.

\section{Quantitative Performance Criteria, Indicative Targets, and Continuous Performance Criteria: Definitions and Reporting Standards}

\section{A. Ceiling on the Cash Deficit of the Consolidated Government}

5. Definition: The cash deficit of the consolidated government will be measured from the financing side at current exchange rates, and will be defined as equal to the total financing. Total financing will be defined as the sum of (i) net domestic financing from banks and nonbanks, (ii) net external financing, and (iii) privatization receipts.

- Net domestic financing consists of bank and nonbank financing to the consolidated government which will be defined as follows:

(i) Loans provided by commercial banks to the consolidated government minus accounts held by the consolidated government at commercial banks. These accounts and loans will be monitored based on the NBG's monetary survey. Any other 
securities issued by the consolidated government (for example, promissory notes) are also included in domestic financing.

(ii) Loans provided by the NBG to the consolidated government minus accounts of the consolidated government held at the NBG in lari and foreign currency. Accounts that are outside of the MOF's control are excluded from domestic financing. These accounts include VAT refund account; earmarked grants account; account for state agencies deposits; account for local government revenues for the day to be transferred to their account; national disaster fund account; and investment grant and credit account. As of June 30, 2008, cash balances in these accounts were Lari 160.5 million. These accounts will be monitored based on the changes in cash balances as recorded by the Treasury Department.

(iii) Treasury bills that have been securitized and sold by the NBG, including the bills that have been purchased by nonbanks.

- Net external financing is defined as the total of loans disbursed to the consolidated government for balance-of-payments support and project financing (capital expenditure and net lending), net change in external arrears, change in the accounts of the consolidated government abroad, including the accounts of the Sovereign Wealth Fund, minus amortization. Amortization includes all external debt-related payments of principal by the consolidated government. Amortization to external creditors via third parties is accounted for at the time and in the amount of payment by the budget to the third party, rather than at the time of recognition of amortization by the external creditor.

- $\quad$ Privatization receipts consist of all transfers of monies received by the central and local governments in connection with the sale of central or local government assets, including privatization proceeds which were transferred to the Sovereign Wealth Funds. This includes receipts from the sales of shares, the sale of assets as well as leases and the sale of licenses with duration of 10 years and longer.

6. Adjustor: The fiscal deficit target will be subject to an upward adjustor of up to 388 million Georgian lari (equivalent to 2 percent of projected GDP) for 2008 and 652 million lari (equivalent to 3 percent of projected GDP) for 2009, in the event that concessional donor financing exceeds current declared commitments (Table 2).

\section{Supporting material:}

- $\quad$ Data on domestic bank and nonbank financing will be provided to the IMF by the NBG and the Treasury Department of the MOF within four weeks after the end of the month. 
- Data on external project financing as well as other external borrowing will be provided to the IMF monthly by the Debt Unit at the MOF (specifying projects by creditor) within two weeks of the end of each month.

- Data will be provided at the actual exchange rates.

- $\quad$ Data on the accounts of the Sovereign Wealth Funds will be provided by the NBG.

- Data on privatization receipts will be provided by the Treasury Department of the MOF to the IMF on a monthly basis within two weeks of the end of each month. The data will be consistent with the revenue account(s) in the NBG.

- Data on treasury bills that have been securitized and sold by the NBG, including the bills that have been purchased by nonbanks, will be reported by the NBG on a monthly basis within two weeks of the end of each month.

\section{B. Floor on the Net International Reserves of the NBG}

8. Definition: Net international reserves (NIR) of the NBG in U.S. dollars are defined as foreign assets minus foreign liabilities of the NBG. Foreign assets of the NBG include gold, gross foreign exchange reserves, SDR holdings, and the reserve position in the IMF. Gross foreign exchange reserves of the NBG are defined as liquid, convertible currency claims of the NBG on nonresidents that are readily available. Pledged or otherwise encumbered assets, including (but not limited to) assets used as collateral (or guarantee for third party external liabilities) are excluded from foreign assets. Foreign liabilities shall be defined as outstanding liabilities to the IMF and any other liabilities of the NBG. This defined, the definition of NIR excludes foreign assets stemming from foreign currency deposits of financial institutions at the NBG. For program monitoring purposes, the stock of foreign assets and foreign liabilities of the NBG shall be valued at program exchange rates as described on paragraph 2 above. The stock of NIR amounted to $\$ 1,060$ million as of end-June 2008 (at the program exchange rate).

9. Supporting material: Data on net international reserves (both at actual and program exchange rates) and on net foreign financing (balance of payments support loans; cash grants to the consolidated government; amortization (excluding repayments to the IMF); interest payments on external debt by the MOF and the NBG) will be provided to the IMF in a table on the NBG's foreign exchange flows (which include details of inflows, outflows, and net international reserves) on a monthly basis within two weeks following the end of the month.

\section{Ceiling on Net Domestic Assets of the NBG}

10. Definition: Net domestic assets of the NBG are defined as the difference between its net foreign assets and reserve money. Thus defined, the net domestic assets are the sum of net claims on the government (the sum of loans and treasury bills purchased by the NBG, 
less deposits of the government with the NBG), claims on banks, claims on the rest of the economy, and other items net (comprising the NBG capital accounts, net unclassified assets, counterpart funds and exchange rate revaluation). Performance against the NDA target will be measured at program exchange rates.

11. Supporting material: The NBG will provide to the IMF its balance sheet, which includes data on its net domestic assets, on a monthly basis within two weeks of the end of each month. Data will be provided using both actual and program exchange rates.

\section{Ceiling on Contracting or Guaranteeing of New Nonconcessional External Debt by the Public Sector}

12. Definition: Nonconcessional external loans are defined as loans from lenders other than the IMF with a grant element of less than 35 percent of the value of the loan. The grant element is to be calculated by using currency-specific discount rates reported by the OECD (CIRRs). ${ }^{1}$ For maturities of less than 15 years, the grant element will be calculated based on six-month averages of commercial interest rates. For maturities longer than 15 years, the grant element will be calculated based on 10-year averages. This performance criterion applies not only to debt as defined in point No. 9 of the IMF's Guidelines on Performance Criteria with Respect to External Debt (Decision No. 12274-(00/85) August 24, 2000) but also to commitments contracted or guaranteed for which value has not been received. ${ }^{2}$ Previously contracted nonconcessional external debt that has been rescheduled will be excluded from the definition of "new debt" for the purposes of this performance criterion.

\footnotetext{
${ }^{1}$ An electronic spreadsheet file that shows the relevant discount rates reported by the OECD (CIRRs) will be provided on a periodic basis by IMF staff.

${ }^{2}$ Point No. 9 of the IMF's guidelines reads as follows: "(a) For the purpose of this guideline, the term "debt" will be understood to mean a current, i.e., not contingent, liability, created under a contractual arrangement through the provision of value in the form of assets (including currency) or services, and which requires the obligor to make one or more payments in the form of assets (including currency) or services, at some future point(s) in time; these payments will discharge the principal and/or interest liabilities incurred under the contract. Debts and take a number of forms, the primary ones being as follows: (i) loans, i.e., advances of money to obligor by the lender made on the basis of an undertaking that the obligor will repay the funds in the future (including deposits, bonds, debentures, commercial loans and buyers' credits) and temporary exchanges of assets that are equivalent to fully collateralized loans under which the obligor is required to repay the funds, and usually pay interest, by repurchasing the collateral from the buyer in the future (such as repurchase agreements and official swap arrangements); (ii) suppliers' credits, i.e., contracts where the supplier permits the obligor to defer payments until some time after the date on which the goods are delivered or services are provided; and (iii) leases, i.e., arrangements under which property is provided which the lessee has the right to use for one or more specified period(s) of time that are usually shorter than the total expected service life of the property, while the leaser retains the title to the property. For the purpose of the Guideline, the debt is the present value (at the inception of the lease) of all lease payments expected to be made during the period of the agreement excluding those payments that cover the operation, repair, or maintenance of the property. (b) Under the definition of debt set out in point 9(a) above, arrears, penalties, and judicially awarded damages arising from the failure to make payment under a contractual obligation that constitutes debt are debt. Failure to make payment on an obligation that is not considered debt under this definition (e.g., payment on delivery) will not give rise to debt."
} 
13. Supporting material: Details of all new commitments and government guarantees for external borrowing, with detailed explanations, will be provided by the MOF to the IMF on a monthly basis within two weeks of the end of each month. Data will be provided using actual exchange rates.

\section{E. Continuous Performance Criteria on Nonaccumulation of External Arrears}

14. Definition: During the period of the arrangement, the consolidated government and the NBG will not accumulate any new external payment arrears on debt service obligations to official creditors, including the IMF and the World Bank. Official external payment arrears are defined as unpaid debt service by the consolidated government and the NBG beyond the due date. The performance criterion on nonaccumulation of external debt is continuous.

15. Supporting material: Details of official arrears accumulated on interest and principal payments to creditors will be reported to the IMF within one week from the date of the missed payment. Data will be provided using actual exchange rates.

Table 1. Program Exchange Rates

\begin{tabular}{ccc}
\hline & Currency Name & Currency/US\$ \\
\hline SDR & Special Drawing Rights & 1.58 \\
GEL & Georgian lari & 1.41 \\
EUR & Euro & 1.48 \\
\hline
\end{tabular}

Table 2. Projected Foreign Borrowing of the Consolidated Government 1/ (in millions of U.S. Dollars)

\begin{tabular}{cr}
\hline September 30, 2008 & 8.7 \\
December 31, 2008 & 50.4 \\
March 31, 2009 & 7.0 \\
June 30, 2009 & 29.4 \\
\hline
\end{tabular}

1/ Cumulative from June 30, 2008 for 2008; for 2009, cumulative from the beginning of the calendar year. 


\section{Attachment IV. Georgia: External and Public Sector Debt Sustainability ANALYSIS $^{1}$}

The staff's debt sustainability analysis shows that Georgia's external debt is low. ${ }^{2}$ Although the debt ratios will rise over the next two years as the government receives foreign financing for post-conflict reconstruction in the wake of the recent conflict, the debt outlook is expected to recover and improve over the medium term. Key medium-term risks involve large debt service in 2012-13 associated with the repayments to the Fund (under the proposed SBA) and the 2008 Eurobond.

\section{A. Background}

1. This update reflects the macroeconomic framework underlying the new SBA and staff projections through 2028. It assumes that implementation of prudent macroeconomic policies and further improvements in the business climate will help Georgia overcome the adverse economic and financial consequences of the recent armed conflict. In particular, investor confidence is restored by 2010 , when capital inflows return to pre-conflict levels, spurring economic growth and export diversification.

\section{Georgia's stock of}

external debt as of end-2007 is estimated at $\$ 3.1$ billion $(303 / 4$ percent of GDP). ${ }^{3}$ For the first time the DSA includes actual data on private sector debt based on a survey conducted by the National Bank of Georgia. ${ }^{4}$ Of the total amount, \$1,790 (57 percent of total) represents public or publiclyguaranteed (PPG) debt, while the

\begin{tabular}{lrrr}
\multicolumn{4}{c}{ Georgia: Structure of External Debt, 2007} \\
\hline & In USD & $\begin{array}{r}\text { In percent of } \\
\text { GDP }\end{array}$ & $\begin{array}{r}\text { Net Present } \\
\text { Value, USD }\end{array}$ \\
\hline Total External Debt & 3136 & 30.7 & \\
Public debt & 1790 & 17.5 & 1349 \\
World Bank & 883 & 8.6 & 531 \\
IMF & 249 & 2.4 & 207 \\
Paris Club & 429 & 4.2 & 357 \\
Others & 229 & 2.2 & 253 \\
Private debt & 1346 & 13.2 & \\
Corporate sector & 287 & 2.8 & \\
Financial sector & 1059 & 10.4 & \\
\hline
\end{tabular}

Source: Georgian authorities; and Fund staff estimates.

\footnotetext{
${ }^{1}$ This is a Fund staff update to the joint World Bank/IMF DSA presented in the report for the Fourth Review under the PRGF (Country Report No. 06/395). The joint World Bank/IMF DSA will be prepared on the occasion of the next Article IV consultation.

${ }^{2}$ Georgia is rated as a strong performer based on the World Bank's Country Performance and Institutional Assessment Index. The relevant policy-dependent thresholds are 50 percent for the NPV of the debt-to-GDP ratio, 200 percent for the NPV of debt-to-exports ratio, 300 percent for the NPV of debt-to-revenue ratio, 25 percent of the debt service-to-exports ratio, and 35 percent of the debt service-to-revenue ratio.

${ }^{3}$ The public external debt data used for this exercise were updated by staff using information provided by the authorities for the stock of debt as of end-2007.

${ }^{4}$ Private debt stock data could be subject to further revisions. For debt service on existing debt no actual data are available and staff had to approximate debt service projections based on tentative terms.
} 
remaining amount consists of private debt incurred by the corporate and financial sectors. The average grant element of the PPG debt is 25 percent.

3. Several years of strong growth and prudent debt management policies have helped to reduce Georgia's external PPG debt burden. Over the last decade, the PPG debt has fallen from 50 percent of GDP in 2000 to about 171/2 percent in 2007 . While in 2000 almost 15 percent of export receipts was directed to service the PPG debt, the ratio fell to 5 percent in 2007. The composition of PPG debt by creditor has shifted from bilateral creditors to multilateral institutions, resulting in a higher degree of concessionality.

4. Large private capital inflows have been among the key drivers of Georgia's strong growth in recent years. These inflows increased from $\$ 1 / 2$ billion in 2004 to $\$ 2.2$ billion in 2007 contributing to a build-up of sizeable private external debt. While FDI has continued to make up 70 percent of private capital inflows in recent years, the debtcreating inflows (primarily corporate and bank loans) have almost tripled since 2005.

\section{B. Developments in 2008}

5. This year marked a shift in the debt management policy as the government tapped international markets with a \$500 million Eurobond issue in April 2008. The proceeds were intended to bolster the country's liquid resources for dealing with future shocks.

6. The near-term debt outlook will be adversely affected by the August armed conflict. First, some of the recent gains in debt ratios will be temporarily reversed as the government resorts to external financing to address the balance-of-payments pressures in Georgia's capital account and to pay for large reconstruction in the wake of the conflict. Part of the balance-of-payments gap is expected to be filled with the proposed $\$ 750$ million SBA from the Fund. Second, the weakened investor confidence has reduced the availability of external financing and increased borrowing costs for Georgian banks.

\section{Underlying Assumptions}

7. The medium- and long-term macroeconomic projections and assumptions regarding the composition and terms of new borrowing are as follow:

- $\quad$ Growth is expected to remain low in 2008 and 2009, but would recover to 6-7 percent in the medium term. As Georgia progresses toward a higher income level, the growth rate would stabilize at its long-term level of 4.5 percent.

- $\quad$ Exports volume growth is projected to average more than 8 percent over 2008-12, reflecting a strong rebound from the recent conflict. Over the long term, export growth would be sustained at 5-5 $\frac{1}{2}$ percent, supported by strong FDI and favorable external demand. Imports would remain buoyant with annual growth of more than 
6 percent over the medium term, before converging to the long-term growth of about $4 \frac{1}{2}$ percent, consistent with the assumed GDP growth.

- $\quad$ The current account deficit is expected to widen to $203 / 4$ percent of GDP in 2008 . Thereafter, strong exports growth, especially in services, will contribute to a decline in the deficit, bringing it to $73 / 4$ percent by the end of the DSA's horizon.

- $\quad$ Fiscal revenues, which are projected at 28 percent of GDP in 2008, would gradually converge to the long-term level of 24 percent of GDP, reflecting the government's intention to limit the role of the government in the economy. Expenditures will decline too, reaching 21 percent of GDP by the end of projection period. This implies a decline in the overall deficit from about 53/4 percent of GDP in 2008 and 2009 to a balanced budget by $2012-13$, followed by small surpluses over the remaining projection period.

- $\quad$ The government would continue to contract new loans at concessional terms. Nevertheless, following the 2008 Eurobond issue, this DSA assumes that an increasing share of financing will come from private markets at commercial terms. As a result, the grant element of the new public borrowing would decline from the projected 26 percent in 2009 to 5 percent by the end of the projection period.

- $\quad$ The DSA assumes that a friendly business environment and prudent macroeconomic policies will continue to make Georgia attractive to foreign capital notwithstanding the temporary impact of the recent conflict. Capital inflows would help sustain the high rates of growth and finance the relatively large current account deficit. As a result, private external debt is expected to reach 15-16 percent of GDP over the medium term and remain at that level thereafter.

\section{Assessment of Debt Sustainability}

\section{Georgia's public debt ratios will remain low despite the need to resort to increased foreign financing in 2008 and 2009.}

- $\quad$ Substantial one-off borrowing in the wake of the conflict would lead to a temporary increase in the level of external public debt. ${ }^{5}$ The external public debt will peak in 2009 at 26 percent of GDP (compared to $17 \frac{1}{2}$ percent in 2007), but is expected to decline gradually over the medium- to long-term. By the end of the projection period,

\footnotetext{
${ }^{5}$ The existing guidelines require staff to justify growth projections if the baseline includes very large upfront borrowing (an increase of NPV of debt of 5 percent of GDP or more). This, however, would not be fully applicable to the case of Georgia, as the assumed large borrowing is necessitated by the financing needs in the wake of the conflict. Furthermore, staff's growth projections are conservative, especially when compared with the recent impressive growth rates.
} 
the external public debt is estimated to fall below 7 percent of GDP, with the net present value (NPV) at 6 percent of GDP.

- $\quad$ Since external debt accounts for more than 90 percent of total public debt, the public DSA results are similar to the external DSA findings. They show a continued decline in solvency ratios as the NPV of debt-to-revenue ratio is projected to decline from 75 percent of GDP in 2008 to 32 percent of GDP by 2028. The debt service ratios are manageable and remain on a declining path.

\section{The maturity structure of debt contracted in 2008 could present some} repayment challenges in 2012-2013. The external public debt service will remain manageable with debt service-to-revenue ratios falling over the DSA horizon. However, the repayment of the $\$ 500$ million 2008 Eurobond maturing in 2013 could put a serious strain on the budget unless the government manages to successfully rollover its debt. In addition, the purchases under the SBA are expected to fall due in 2011-2014, putting pressure on the balance of payments. Reflecting these repayments, the external public debt service-to-exports ratio is expected to peak at $16 \frac{1}{2}$ percent in 2013 before falling back to $3-4$ percent over the long term.

\section{Georgia's debt outlook shows resiliency to a number of exogenous shocks as} demonstrated by the results of alternative scenarios and stress testing. External public debt solvency and liquidity ratios would remain well below the thresholds applicable to Georgia under most scenarios. The NPV of debt-to-GDP ratio is most vulnerable at a 30 percent nominal depreciation relative to the assumed baseline, while the NPV of debt-toexports ratio would deviate most from its baseline path under the rate of export growth one standard deviation below the historic average. The stress tests shown in the table on public debt suggest that keeping the primary balance unchanged from 2008 on would imply a major deterioration in the debt ratios, with the NPV of debt-to-revenue ratio approaching 250 percent. This result is somewhat misleading and should be interpreted with caution as the primary balance deficit in 2008 is the result of a large one-off spending in the wake of the recent conflict. To test the sensitivity of debt outlook to large nonconcessional public borrowing, staff conducted a stress test that assumes new borrowing of $\$ 500$ million over 2008-2009 (program limit) at commercial terms. The results point to a deterioration in debt ratios in the near term, with the NPV of public external debt-to-GDP-ratio reaching 25 percent in 2009-5 percentage points above the baseline scenario. Debt service ratios would also be substantially above those under the baseline assumptions. 
Figure 1. Georgia: Indicators of Public and Publicly Guaranteed External Debt under Alternatives Scenarios, 2008-2028 1/
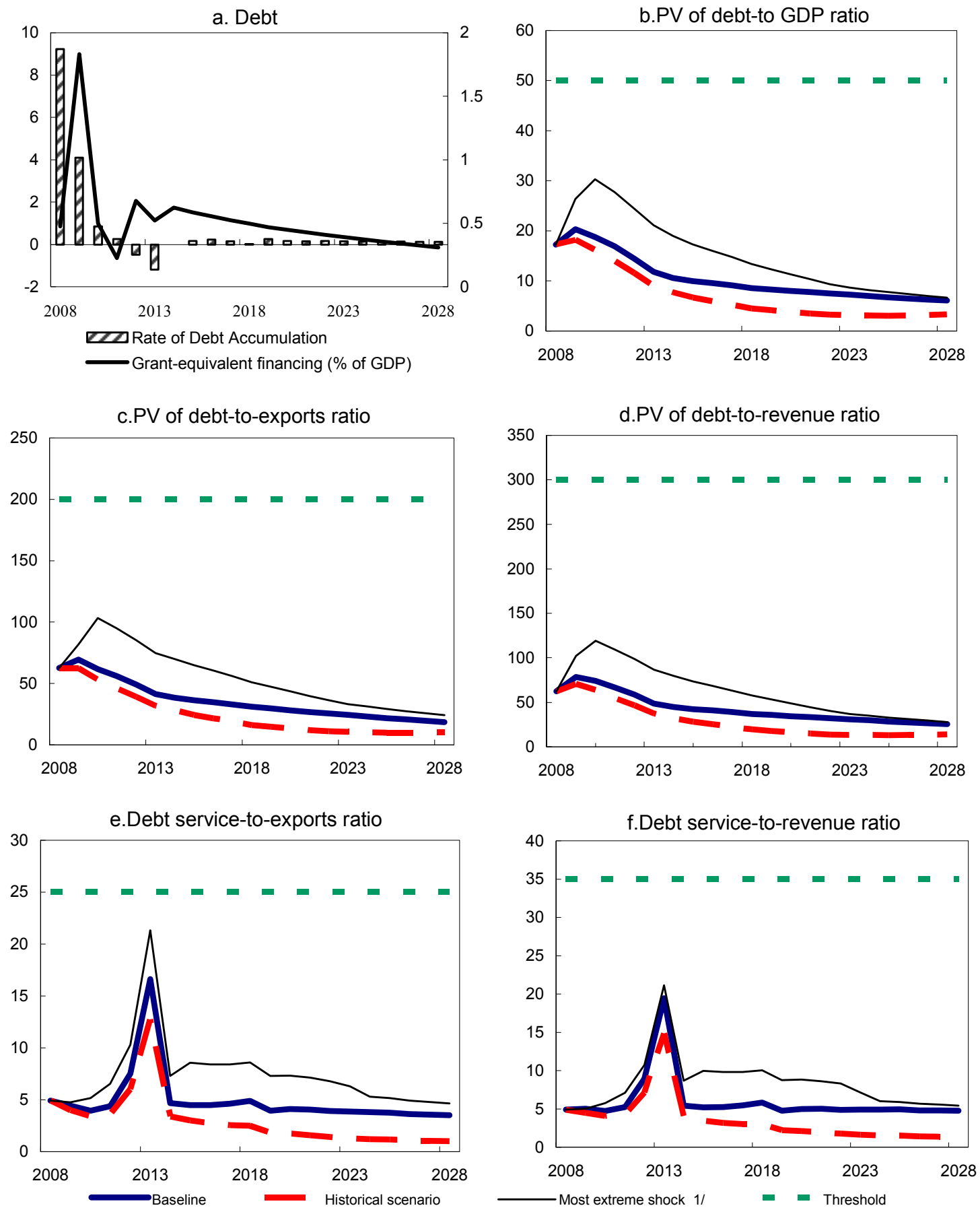

Source: Staff projections and simulations.

$1 /$ The most extreme stress test is the test that yields the highest ratio in 2018. In figure $b$. it corresponds to a Non-debt flows shock; in c. to a Exports shock; in d. to a Non-debt flows shock; in e. to a Exports shock and in picture f. to a Nondebt flows shock 
Figure 2.Georgia: Indicators of Public Debt Under Alternative Scenarios, 2008-2028 1/

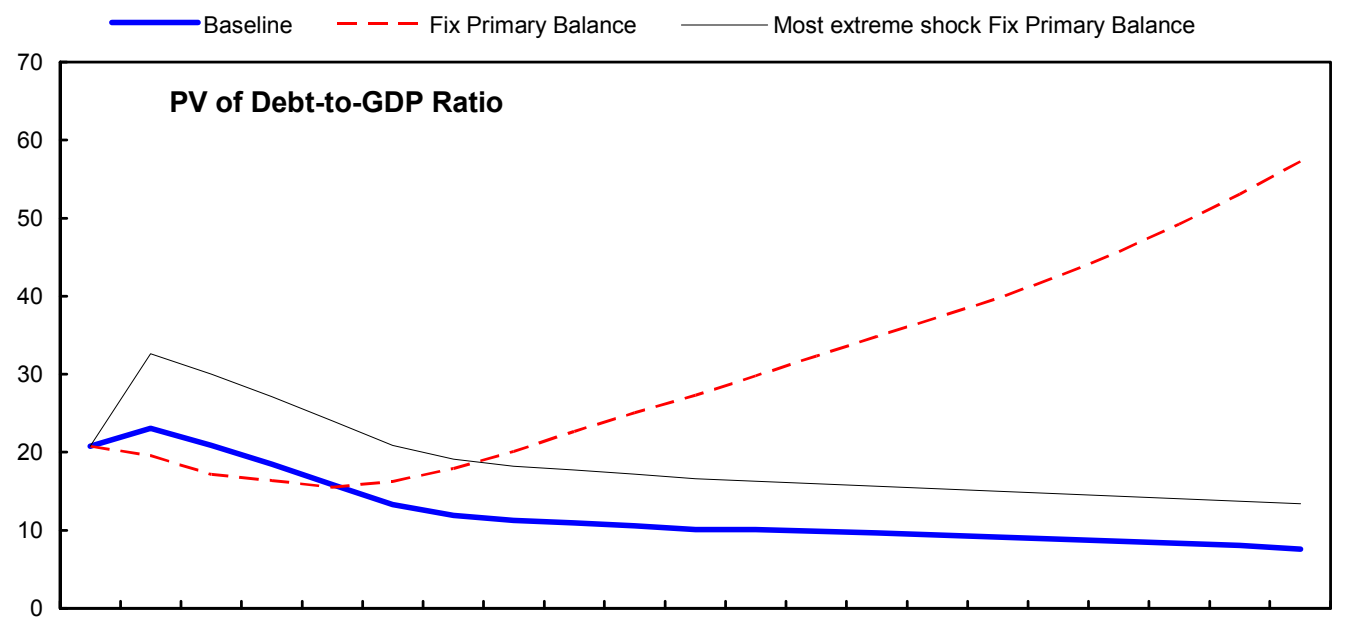

200820092010201120122013201420152016201720182019202020212022202320242025202620272028

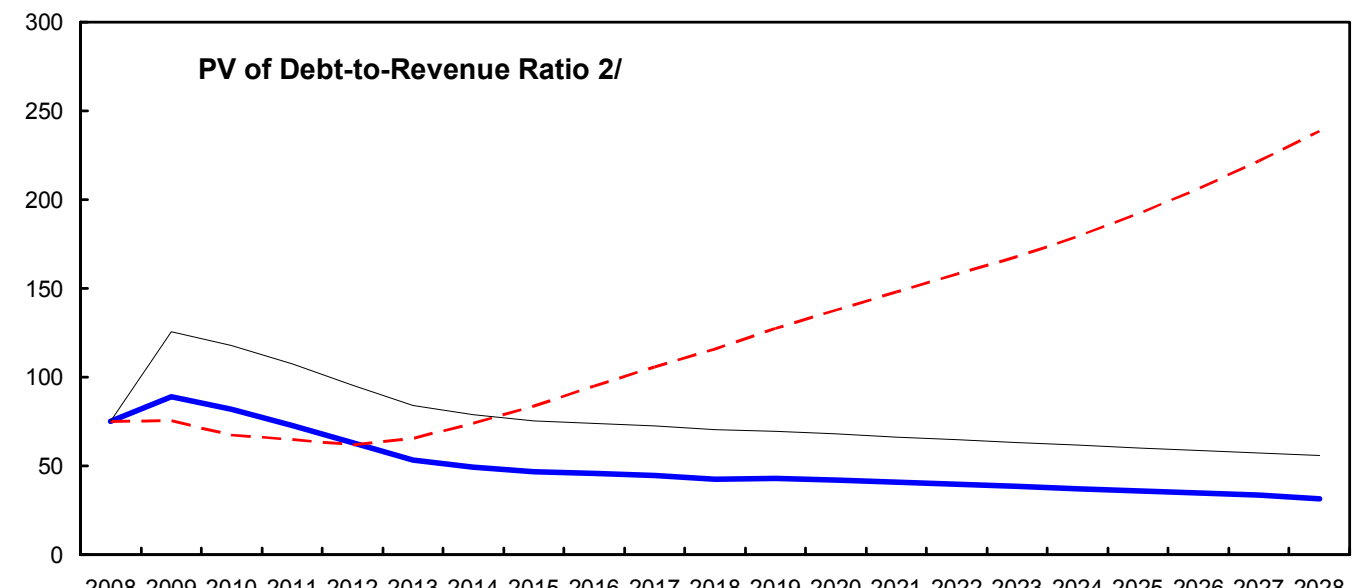

200820092010201120122013201420152016201720182019202020212022202320242025202620272028

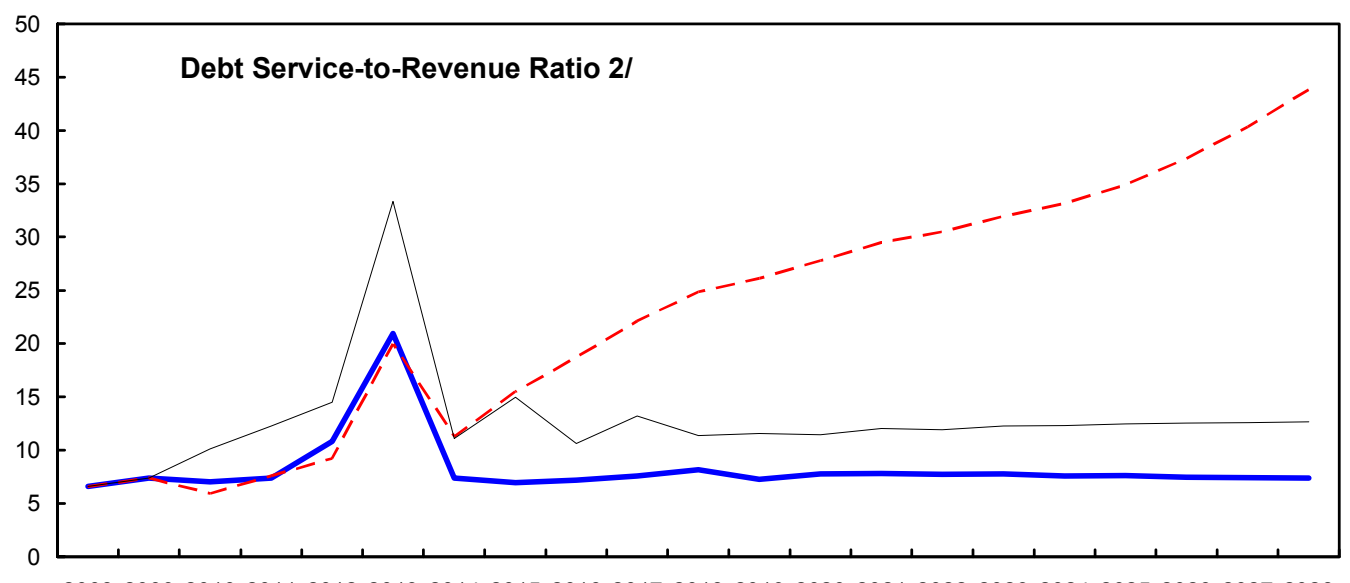

200820092010201120122013201420152016201720182019202020212022202320242025202620272028

Sources: Country authorities; and Fund staff estimates and projections.

$1 /$ The most extreme stress test is the test that yields the highest ratio in 2018.

2/ Revenues are defined inclusive of grants. 
Table 1a. Georgia: External Debt Sustainability Framework, Baseline Scenario, 2005-2028 1/

(In percent of GDP, unless otherwise indicated)

\begin{tabular}{|c|c|c|c|c|c|c|c|c|c|c|c|c|c|c|c|}
\hline & \multicolumn{3}{|c|}{ Actual } & \multirow{2}{*}{$\begin{array}{c}\text { Historical } \\
\text { Average 6/ }\end{array}$} & \multirow{2}{*}{$\begin{array}{c}\text { Standard } \\
\text { Deviation 6/ }\end{array}$} & \multicolumn{6}{|c|}{ Projections } & \multirow{2}{*}{$2008-2013$} & \multirow[b]{2}{*}{2018} & \multirow[b]{2}{*}{2028} & \multirow{2}{*}{$2014-2028$} \\
\hline & 2005 & 2006 & 2007 & & & 2008 & 2009 & 2010 & 2011 & 2012 & 2013 & & & & \\
\hline External debt (nominal) $1 /$ & 32.7 & 30.0 & 30.7 & & & 34.6 & 41.1 & 39.5 & 37.7 & 34.7 & 31.4 & & 26.6 & 21.9 & \\
\hline $\mathrm{o} / \mathrm{w}$ public and publicly guaranteed (PPG) & 27.1 & 21.9 & 17.5 & & & 21.0 & 25.9 & 24.1 & 21.5 & 18.3 & 15.2 & & 11.0 & 6.9 & \\
\hline Change in external debt & -9.0 & -2.7 & 0.7 & & & 3.9 & 6.5 & -1.6 & -1.7 & -3.0 & -3.3 & & -1.0 & -0.4 & \\
\hline Identified net debt-creating flows & -4.9 & -3.6 & -2.5 & & & 10.6 & 8.8 & 4.5 & 2.9 & 1.6 & 1.7 & & 1.1 & 0.6 & \\
\hline Non-interest current account deficit & 11.1 & 14.8 & 18.7 & 9.6 & 4.9 & 18.9 & 16.6 & 13.8 & 12.1 & 10.4 & 9.7 & & 7.5 & 7.0 & 7.4 \\
\hline Deficit in balance of goods and services & 17.7 & 23.8 & 26.2 & & & 25.9 & 23.6 & 20.1 & 18.4 & 16.1 & 15.0 & & 12.2 & 11.6 & \\
\hline Exports & 34.1 & 33.1 & 31.7 & & & 27.6 & 29.2 & 30.4 & 30.2 & 29.4 & 28.5 & & 27.7 & 32.5 & \\
\hline Imports & 51.8 & 56.8 & 57.8 & & & 53.4 & 52.9 & 50.5 & 48.6 & 45.5 & 43.5 & & 39.9 & 44.1 & \\
\hline Net current transfers (negative $=$ inflow) & -4.6 & -5.7 & -5.7 & -5.7 & 0.7 & -6.4 & -6.6 & -5.8 & -5.4 & -5.0 & -4.7 & & -4.0 & -3.7 & -4.0 \\
\hline Other current account flows (negative = net inflow) & -2.0 & -3.3 & -1.7 & & & -0.6 & -0.4 & -0.5 & -0.9 & -0.7 & -0.6 & & -0.6 & -0.9 & \\
\hline Net FDI (negative $=$ inflow) & -8.5 & -13.9 & -15.3 & -8.4 & 4.5 & -9.3 & -8.6 & -9.2 & -9.2 & -8.5 & -8.2 & & -6.8 & -7.0 & -6.9 \\
\hline Endogenous debt dynamics 2 & -7.5 & -4.6 & -5.9 & & & 1.1 & 0.8 & -0.1 & 0.0 & -0.3 & 0.2 & & 0.4 & 0.6 & \\
\hline Contribution from nominal interest rate & 0.8 & 1.1 & 1.3 & & & 1.9 & 2.1 & 2.1 & 2.1 & 2.0 & 2.0 & & 1.6 & 1.6 & \\
\hline Contribution from real GDP growth & -3.2 & -2.5 & -2.8 & & & -0.8 & -1.3 & -2.2 & -2.1 & -2.3 & -1.9 & & -1.2 & -0.9 & \\
\hline Contribution from price and exchange rate changes & -5.2 & -3.2 & -4.4 & & & & & & & & & & & & \\
\hline Residual (3-4) 3/ & -4.1 & 0.9 & 3.2 & & & -6.7 & -2.3 & -6.2 & -4.6 & -4.6 & -5.0 & & -2.1 & -1.0 & \\
\hline o/w exceptional financing & -1.0 & -0.1 & -0.6 & & & 0.0 & 0.0 & 0.0 & 0.0 & 0.0 & 0.0 & & 0.0 & 0.0 & \\
\hline PV of external debt $4 /$ & $\ldots$ & $\ldots$ & 26.4 & & & 30.9 & 35.5 & 34.2 & 33.1 & 30.8 & 28.1 & & 24.1 & 21.0 & \\
\hline In percent of exports & $\ldots$ & $\ldots$ & 83.2 & & & 112.0 & 121.6 & 112.3 & 109.7 & 104.9 & 98.7 & & 87.1 & 64.7 & \\
\hline PV of PPG external debt & $\ldots$ & $\ldots$ & 13.2 & & & 17.3 & 20.3 & 18.7 & 16.9 & 14.5 & 11.8 & 16.6 & 8.6 & 6.1 & 7.9 \\
\hline Debt service-to-exports ratio (in percent) & 17.0 & 14.3 & 13.7 & & & 11.7 & 12.4 & 12.2 & 13.3 & 17.3 & 27.1 & 15.7 & 17.7 & 14.3 & 16.0 \\
\hline PPG debt service-to-exports ratio (in percent) & 10.5 & 9.7 & 4.4 & & & 4.9 & 4.4 & 4.0 & 4.4 & 7.5 & 16.6 & 7.0 & 4.9 & 3.5 & 4.1 \\
\hline PPG debt service-to-revenue ratio (in percent) & 12.2 & 12.6 & 4.9 & & & 4.9 & 5.0 & 4.7 & 5.2 & 9.0 & 19.4 & 8.0 & 5.8 & 4.8 & 5.1 \\
\hline Total gross financing need (Billions of U.S. dollars) & 0.5 & 0.4 & 0.8 & & & 1.7 & 1.9 & 1.6 & 1.4 & 1.7 & 2.4 & & 2.2 & 3.3 & \\
\hline Non-interest current account deficit that stabilizes debt ratio & 20.1 & 17.5 & 18.0 & & & 14.9 & 10.1 & 15.4 & 13.8 & 13.5 & 13.0 & & 8.5 & 7.4 & \\
\hline \multicolumn{16}{|l|}{ Key macroeconomic assumptions } \\
\hline Real GDP growth (in percent) & 9.6 & 9.4 & 12.4 & 6.6 & 3.7 & 3.5 & 4.0 & 6.0 & 6.0 & 7.0 & 6.0 & 5.4 & 4.5 & 4.5 & 4.5 \\
\hline GDP deflator in US dollar terms (change in percent) & 14.1 & 10.7 & 17.2 & 10.0 & 8.1 & 25.5 & 1.2 & 6.5 & 6.0 & 6.0 & 6.0 & 8.5 & 1.9 & 1.0 & 1.7 \\
\hline Effective interest rate (percent) 5/ & 2.5 & 4.0 & 5.7 & 3.1 & 1.0 & 8.0 & 6.5 & 5.8 & 6.0 & 6.0 & 6.6 & 6.5 & 6.1 & 7.3 & 6.7 \\
\hline Growth of exports of G\&S (US dollar terms, in percent) & 32.8 & 17.6 & 26.1 & 18.0 & 14.3 & 13.1 & 11.5 & 17.5 & 11.5 & 10.5 & 8.8 & 12.2 & 7.1 & 7.4 & 7.3 \\
\hline Growth of imports of G\&S (US dollar terms, in percent) & 33.1 & 33.0 & 34.0 & 17.0 & 17.3 & 20.0 & 4.1 & 7.9 & 8.0 & 6.3 & 7.3 & 8.9 & 6.5 & 6.8 & 6.4 \\
\hline Grant element of new public sector borrowing (in percent) & & & & $\ldots$ & $\ldots$ & 5.7 & 25.6 & 26.2 & 27.7 & 27.3 & 0.4 & 18.8 & 10.2 & 4.8 & 8.6 \\
\hline Government revenues (excluding grants, in percent of GDP) & 29.2 & 25.5 & 28.6 & & & 27.7 & 25.8 & 25.4 & 25.4 & 24.7 & 24.4 & & 23.2 & 23.8 & 23.5 \\
\hline Aid flows (in Billions of US dollars) 71 & 0.1 & 0.2 & 0.2 & & & 0.6 & 1.5 & 1.8 & 1.9 & 1.8 & 1.6 & & 2.1 & 2.3 & \\
\hline o/w Grants & 0.1 & 0.1 & 0.1 & & & 0.0 & 0.0 & 0.0 & 0.0 & 0.1 & 0.1 & & 0.1 & 0.1 & \\
\hline o/w Concessional loans & 0.1 & 0.1 & 0.1 & & & 0.6 & 1.5 & 1.8 & 1.8 & 1.8 & 1.5 & & 2.0 & 2.2 & \\
\hline Grant-equivalent financing (in percent of GDP) 8/ & $\ldots$ & $\ldots$ & $\ldots$ & & & 0.5 & 1.8 & 0.5 & 0.2 & 0.7 & 0.5 & & 0.5 & 0.3 & 0.4 \\
\hline Grant-equivalent financing (in percent of external financing) $8 /$ & $\ldots$ & $\ldots$ & $\ldots$ & & & 5.7 & 27.3 & 29.3 & 28.7 & 48.1 & 15.0 & & 35.4 & 25.1 & 32.3 \\
\hline \multicolumn{16}{|l|}{ Memorandum items: } \\
\hline Nominal GDP (Billions of US dollars) & 6.4 & 7.8 & 10.2 & & & 13.3 & 14.0 & 15.8 & 17.7 & 20.1 & 22.6 & & 32.8 & 56.7 & \\
\hline Nominal dollar GDP growth & 25.1 & 21.1 & 31.7 & & & 29.9 & 5.2 & 12.9 & 12.4 & 13.4 & 12.4 & 14.3 & 6.5 & 5.5 & 6.3 \\
\hline PV of PPG external debt (in Billions of US dollars) & & & 1.3 & & & 2.3 & 2.8 & 3.0 & 3.0 & 2.9 & 2.7 & & 2.8 & 3.4 & \\
\hline
\end{tabular}

Source: Staff simulations.

2/ Derived as $[r-g-r(1+g)] /(1+g+r+g r)$ times previous period debt ratio, with $r=$ nominal interest rate; $g=$ real GDP growth rate, and $r=$ growth rate of GDP deflator in U.S. dollar terms

$3 /$ Includes exceptional financing (i.e., changes in arrears and debt relief); changes in gross foreign assets; and valuation adjustments. For projections also includes contribution from price and exchange rate changes.

4/ Assumes that PV of private sector debt is equivalent to its face value.

5/ Current-year in of private seclor debt is equivient to its face value.

$6 /$ Historical averages and standard deviations are generally derived over the past 10 years, subject to data availability.

8/ Grant-equivalent financing includes grants provided directly to the government and through new borrowing (difference between the face value and the PV of new debt). 
Table 1b.Georgia: Sensitivity Analysis for Key Indicators of Public and Publicly Guaranteed External Debt, 2008-2028 (In percent)

PV of debt-to GDP ratio
Baseline
A. Alternative Scenarios
A1. Key variables at their historical averages in 2008-2028 1/
A2. New public sector loans on less favorable terms in 2008-2028 2
B. Bound Tests
B1. Real GDP growth at historical average minus one standard deviation in 2009-2010
B2. Export value growth at historical average minus one standard deviation in 2009-2010 3/
B3. US dollar GDP deflator at historical average minus one standard deviation in 2009-2010
B4. Net non-debt creating flows at historical average minus one standard deviation in 2009-2010 4/
B5. Combination of B1-B4 using one-half standard deviation shocks
B6. One-time 30 percent nominal depreciation relative to the baseline in 2009 5/

$\begin{array}{llllllll}2008 & 2009 & 2010 & 2011 & 2012 & 2013 & 2018 & 2028\end{array}$

\section{PV of debt-to-exports ratio}

Baseline

\section{A. Alternative Scenarios}

A1. Key variables at their historical averages in 2008-2028 1/ A2. New public sector loans on less favorable terms in 2008-2028 2

$\begin{array}{rrrrrrrr}17 & 20 & 19 & 17 & 14 & 12 & 9 & 6 \\ & & & & & & & \\ 17 & 18 & 16 & 14 & 12 & 9 & \mathbf{5} & 3 \\ 17 & 25 & 23 & 21 & 18 & 16 & \mathbf{1 3} & 12\end{array}$

\section{B. Bound Tests}

B1. Real GDP growth at historical average minus one standard deviation in 2009-2010

B2. Export value growth at historical average minus one standard deviation in 2009-2010 3/

B3. US dollar GDP deflator at historical average minus one standard deviation in 2009-2010

B4. Net non-debt creating flows at historical average minus one standard deviation in 2009-2010 4/

B5. Combination of B1-B4 using one-half standard deviation shocks

B6. One-time 30 percent nominal depreciation relative to the baseline in $20095 /$

\section{PV of debt-to-revenue ratio}

Baseline

$\begin{array}{rrrrrrr}21 & 20 & 18 & 15 & 12 & \mathbf{9} & 6 \\ 22 & 26 & 24 & 21 & 18 & \mathbf{1 2} & 6 \\ 20 & 19 & 18 & 15 & 12 & \mathbf{9} & 6 \\ 26 & 30 & 28 & 24 & 21 & \mathbf{1 3} & 7 \\ 22 & 25 & 23 & 20 & 17 & \mathbf{1 1} & 6 \\ 29 & 27 & 24 & 21 & 17 & \mathbf{1 2} & 9\end{array}$

\section{A. Alternative Scenarios}

A1. Key variables at their historical averages in 2008-2028 1/

A2. New public sector loans on less favorable terms in 2008-2028 2

$\begin{array}{llllllll}62 & 71 & 64 & 55 & 47 & 37 & \mathbf{1 9} & 14 \\ 62 & 96 & 92 & 83 & 74 & 64 & \mathbf{5 7} & 49\end{array}$

\section{B. Bound Tests}

B1. Real GDP growth at historical average minus one standard deviation in 2009-2010

B2. Export value growth at historical average minus one standard deviation in 2009-2010 3/

B3. US dollar GDP deflator at historical average minus one standard deviation in 2009-2010

B4. Net non-debt creating flows at historical average minus one standard deviation in 2009-2010 4/

B5. Combination of B1-B4 using one-half standard deviation shocks

B6. One-time 30 percent nominal depreciation relative to the baseline in 2009 /

$\begin{array}{llllllll}63 & 62 & 53 & 46 & 39 & 32 & \mathbf{1 6} & 10 \\ 63 & 85 & 77 & 70 & 63 & 55 & \mathbf{4 8} & 36\end{array}$

$\begin{array}{rrrrrrrr}63 & 69 & 62 & 56 & 49 & 41 & \mathbf{3 1} & 19 \\ 63 & 82 & 103 & 95 & 85 & 75 & \mathbf{5 1} & 24 \\ 63 & 69 & 62 & 56 & 49 & 41 & \mathbf{3 1} & 19 \\ 63 & 90 & 100 & 92 & 83 & 74 & \mathbf{4 8} & 21 \\ 63 & 80 & 93 & 85 & 76 & 67 & \mathbf{4 5} & 21 \\ 63 & 69 & 62 & 56 & 49 & 41 & \mathbf{3 1} & 19\end{array}$

$\begin{array}{rrrrrrrr}62 & 79 & 77 & 69 & 61 & 50 & \mathbf{3 8} & 26 \\ 62 & 86 & 102 & 93 & 83 & 72 & \mathbf{5 0} & 27 \\ 62 & 78 & 77 & 69 & 61 & 50 & \mathbf{3 8} & 26 \\ 62 & 102 & 119 & 109 & 99 & 87 & \mathbf{5 8} & 28 \\ 62 & 86 & 100 & 91 & 82 & 71 & \mathbf{4 9} & 26 \\ 62 & 112 & 105 & 95 & 83 & 69 & \mathbf{5 2} & 36\end{array}$


Table 1b.Georgia: Sensitivity Analysis for Key Indicators of Public and Publicly Guaranteed External Debt, 2008-2028 (continued) (In percent)

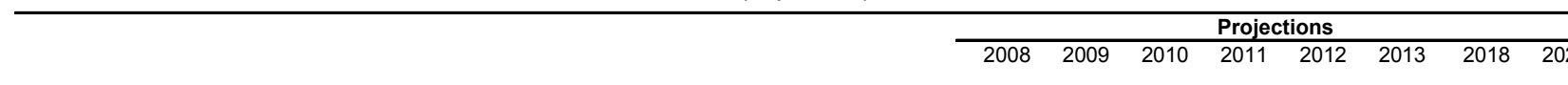

Debt service-to-exports ratio

Baseline

A. Alternative Scenarios

A1. Key variables at their historical averages in 2008-2028 1/

A2. New public sector loans on less favorable terms in 2008-2028 2

\section{B. Bound Tests}

B1. Real GDP growth at historical average minus one standard deviation in 2009-2010

B2. Export value growth at historical average minus one standard deviation in 2009-2010 3/

B3. US dollar GDP deflator at historical average minus one standard deviation in 2009-2010

B4. Net non-debt creating flows at historical average minus one standard deviation in 2009-2010 4/

B5. Combination of B1-B4 using one-half standard deviation shocks

B6. One-time 30 percent nominal depreciation relative to the baseline in $20095 /$

\section{Debt service-to-revenue ratio}

\section{Baseline}

\section{A. Alternative Scenarios}

A1. Key variables at their historical averages in 2008-2028 1/

A2. New public sector loans on less favorable terms in 2008-2028 2

\section{B. Bound Tests}

B1. Real GDP growth at historical average minus one standard deviation in 2009-2010

B2. Export value growth at historical average minus one standard deviation in 2009-2010 3/

B3. US dollar GDP deflator at historical average minus one standard deviation in 2009-2010

B4. Net non-debt creating flows at historical average minus one standard deviation in 2009-2010 4/

B5. Combination of B1-B4 using one-half standard deviation shocks

B6. One-time 30 percent nominal depreciation relative to the baseline in 20095 /

Memorandum item:

Grant element assumed on residual financing (i.e., financing required above baseline) 6/

$\begin{array}{rrrrrrrr}5 & 4 & 4 & 4 & 8 & 17 & 5 & 3 \\ 5 & 4 & 3 & 4 & 6 & 13 & \mathbf{2} & 1 \\ 5 & 4 & 4 & 4 & 3 & 3 & \mathbf{2} & 1\end{array}$

\section{8}

$\begin{array}{rrrrrrrr}5 & 4 & 4 & 4 & 8 & 17 & \mathbf{5} & 3 \\ 5 & 5 & 5 & 7 & 10 & 21 & \mathbf{9} & 5 \\ 5 & 4 & 4 & 4 & 8 & 17 & \mathbf{5} & 3 \\ 5 & 4 & 5 & 6 & 9 & 18 & \mathbf{8} & 4 \\ 5 & 4 & 5 & 6 & 9 & 19 & \mathbf{8} & 4 \\ 5 & 4 & 4 & 4 & 8 & 17 & \mathbf{5} & 3\end{array}$

Source: Staff projections and simulations.

1/ Variables include real GDP growth, growth of GDP deflator (in U.S. dollar terms), non-interest current account in percent of GDP, and non-debt creating flows. $2 /$ Assumes that the interest rate on new borrowing is by 2 percentage points higher than in the baseline., while grace and maturity periods are the same as in the baseline.

3/ Exports values are assumed to remain permanently at the lower level, but the current account as a share of GDP is assumed to return to its baseline level after the shock (implicitly assuming an offsetting adjustment in import levels).

$4 /$ Includes official and private transfers and FDI.

$5 /$ Depreciation is defined as percentage decline in dollar/local currency rate, such that it never exceeds 100 percent.

6/ Applies to all stress scenarios except for A2 (less favorable financing) in which the terms on all new financing are as specified in footnote 2 . 
Table 2a.Georgia: Public Sector Debt Sustainability Framework, Baseline Scenario, 2005-2028

(In percent of GDP, unless otherwise indicated)

\begin{tabular}{|c|c|c|c|c|c|c|c|c|c|c|c|c|c|c|c|}
\hline & \multicolumn{3}{|c|}{ Actual } & \multirow[b]{2}{*}{ Average 5/ } & \multirow{2}{*}{$\begin{array}{r}\text { Standard } \\
\text { Deviation 5/ }\end{array}$} & \multirow{2}{*}{$\begin{array}{c}\text { Estimate } \\
2008\end{array}$} & \multicolumn{9}{|c|}{ Projections } \\
\hline & 2005 & 2006 & 2007 & & & & 2009 & 2010 & 2011 & 2012 & 2013 & $\begin{array}{l}2008-13 \\
\text { Average } \\
\end{array}$ & 2018 & 2028 & $\begin{array}{l}2014-28 \\
\text { Average } \\
\end{array}$ \\
\hline $\begin{array}{l}\text { Public sector debt } 1 / \\
\text { o/w foreign-currency denominated }\end{array}$ & $\begin{array}{l}34.2 \\
27.1\end{array}$ & $\begin{array}{l}27.9 \\
21.9\end{array}$ & $\begin{array}{l}22.4 \\
17.5\end{array}$ & & & $\begin{array}{l}24.5 \\
21.0\end{array}$ & $\begin{array}{l}28.6 \\
25.9\end{array}$ & $\begin{array}{l}26.2 \\
24.1\end{array}$ & $\begin{array}{l}23.1 \\
21.5\end{array}$ & $\begin{array}{l}19.7 \\
18.3\end{array}$ & $\begin{array}{l}16.6 \\
15.2\end{array}$ & & $\begin{array}{l}12.5 \\
11.0\end{array}$ & $\begin{array}{l}8.5 \\
6.9\end{array}$ & \\
\hline Change in public sector debt & -10.6 & -6.3 & -5.6 & & & 2.1 & 4.2 & -2.5 & -3.0 & -3.4 & -3.1 & & -0.7 & -0.3 & \\
\hline Identified debt-creating flows & -9.3 & 1.2 & 3.2 & & & 4.4 & 3.7 & -2.4 & -2.5 & -2.6 & -3.7 & & -2.4 & -4.1 & \\
\hline Primary deficit & -5.5 & 1.0 & 3.8 & -2.6 & 3.8 & 4.9 & 4.7 & 1.4 & -0.4 & -0.7 & -2.4 & 1.3 & -2.1 & -4.0 & -2.5 \\
\hline Revenue and grants & 30.1 & 26.7 & 29.2 & & & 27.7 & 26.0 & 25.5 & 25.4 & 25.1 & 24.9 & & 23.6 & 24.1 & \\
\hline of which: grants & 0.9 & 1.2 & 0.6 & & & 0.0 & 0.2 & 0.1 & 0.0 & 0.4 & 0.5 & & 0.4 & 0.3 & \\
\hline Primary (noninterest) expenditure & 24.6 & 27.7 & 33.1 & & & 32.6 & 30.7 & 26.8 & 25.0 & 24.4 & 22.5 & & 21.5 & 20.1 & \\
\hline Automatic debt dynamics & -7.4 & -5.0 & -5.8 & & & -3.7 & -0.4 & -2.3 & -1.9 & -1.9 & -1.3 & & -0.3 & 0.0 & \\
\hline Contribution from interest rate/growth differential & -4.3 & -3.3 & -3.4 & & & -0.4 & -0.6 & -1.2 & -1.0 & -1.1 & -0.6 & & -0.3 & -0.1 & \\
\hline of which: contribution from average real interest rate & -0.4 & -0.4 & -0.3 & & & 0.3 & 0.4 & 0.4 & 0.4 & 0.4 & 0.5 & & 0.3 & 0.3 & \\
\hline of which: contribution from real GDP growth & -3.9 & -2.9 & -3.1 & & & -0.8 & -0.9 & -1.6 & -1.5 & -1.5 & -1.1 & & -0.6 & -0.4 & \\
\hline Contribution from real exchange rate depreciation & -3.1 & -1.7 & -2.4 & & & -3.3 & 0.2 & -1.1 & -0.9 & -0.8 & -0.7 & & & & \\
\hline Other identified debt-creating flows & 3.6 & 5.2 & 5.2 & & & 3.2 & -0.6 & -1.5 & -0.2 & 0.0 & 0.0 & & 0.0 & 0.0 & \\
\hline Privatization receipts (negative) & 3.6 & 5.2 & 5.2 & & & 3.2 & -0.6 & -1.5 & -0.2 & 0.0 & 0.0 & & 0.0 & 0.0 & \\
\hline Recognition of implicit or contingent liabilities & 0.0 & 0.0 & 0.0 & & & 0.0 & 0.0 & 0.0 & 0.0 & 0.0 & 0.0 & & 0.0 & 0.0 & \\
\hline Debt relief (HIPC and other) & 0.0 & 0.0 & 0.0 & & & 0.0 & 0.0 & 0.0 & 0.0 & 0.0 & 0.0 & & 0.0 & 0.0 & \\
\hline Other (specify, e.g. bank recapitalization) & 0.0 & 0.0 & 0.0 & & & 0.0 & 0.0 & 0.0 & 0.0 & 0.0 & 0.0 & & 0.0 & 0.0 & \\
\hline Residual, including asset changes & -1.3 & -7.5 & -8.8 & & & -2.3 & 0.5 & -0.1 & -0.5 & -0.8 & 0.6 & & 1.6 & 3.7 & \\
\hline \multicolumn{16}{|l|}{ Other Sustainability Indicators } \\
\hline PV of public sector debt & 7.2 & 6.0 & 18.0 & & & 20.8 & 23.1 & 20.9 & 18.5 & 15.9 & 13.3 & & 10.1 & 7.6 & \\
\hline $\mathrm{o} / \mathrm{w}$ foreign-currency denominated & $\ldots$ & $\ldots$ & 13.2 & & & 17.3 & 20.3 & 18.7 & 16.9 & 14.5 & 11.8 & & 8.6 & 6.1 & \\
\hline o/w external & $\ldots$ & $\ldots$ & 13.2 & & & 17.3 & 20.3 & 18.7 & 16.9 & 14.5 & 11.8 & & 8.6 & 6.1 & \\
\hline PV of contingent liabilities (not included in public sector debt) & & & & & & & & & & & & & $\ldots$ & & \\
\hline Gross financing need 21 & -3.5 & -1.2 & 4.7 & & & 5.8 & 7.0 & 6.8 & 3.3 & 1.7 & 2.2 & & -0.1 & -1.8 & \\
\hline PV of public sector debt-to-revenue and grants ratio (in percent) & 23.8 & 22.6 & 61.7 & & & 75.0 & 88.8 & 81.9 & 72.9 & 63.2 & 53.4 & & 42.7 & 31.5 & \\
\hline PV of public sector debt-to-revenue ratio (in percent) & 24.5 & 23.7 & 63.0 & & & 75.0 & 89.4 & 82.2 & 72.9 & 64.3 & 54.5 & & 43.4 & 31.8 & \\
\hline o/w external $3 /$ & & & 46.0 & & & 62.4 & 78.7 & 73.8 & 66.6 & 58.5 & 48.5 & & 36.9 & 25.4 & \\
\hline Debt service-to-revenue and grants ratio (in percent) $4 /$ & 14.2 & 13.8 & 6.0 & & & 6.6 & 7.4 & 7.0 & 7.4 & 10.8 & 21.0 & & 8.2 & 7.4 & \\
\hline Debt service-to-revenue ratio (in percent) $4 /$ & 7.3 & 6.9 & 3.5 & & & 4.8 & 5.3 & 5.1 & 5.1 & 6.4 & 10.9 & & 4.2 & 2.9 & \\
\hline Primary deficit that stabilizes the debt-to-GDP ratio & 5.1 & 7.3 & 9.4 & & & 2.8 & 0.5 & 3.8 & 2.7 & 2.7 & 0.7 & & -1.3 & -3.7 & \\
\hline \multicolumn{16}{|l|}{ Key macroeconomic and fiscal assumptions } \\
\hline Real GDP growth (in percent) & 9.6 & 9.4 & 12.4 & 6.6 & 3.7 & 3.5 & 4.0 & 6.0 & 6.0 & 7.0 & 6.0 & 5.4 & 4.5 & 4.5 & 4.5 \\
\hline Average nominal interest rate on forex debt (in percent) & 1.7 & 1.7 & 1.5 & 2.3 & 0.6 & 4.3 & 3.5 & 3.1 & 3.0 & 2.9 & 3.8 & 3.4 & 2.8 & 3.8 & 3.1 \\
\hline Average real interest rate on domestic debt (in percent) & -3.9 & -2.4 & -8.3 & -5.7 & 3.0 & -14.3 & 8.0 & 5.2 & 9.1 & 13.4 & 15.7 & 6.2 & 15.5 & 13.3 & 15.4 \\
\hline Real exchange rate depreciation (in percent, + indicates depreciation) & -14.5 & -8.8 & -18.1 & -8.2 & 12.0 & -29.0 & & & & & $\ldots$ & & & $\ldots$ & \\
\hline Inflation rate (GDP deflator, in percent) & 14.1 & 10.7 & 17.2 & 10.0 & 8.1 & 25.5 & 1.2 & 6.5 & 6.0 & 6.0 & 6.0 & 8.5 & 1.9 & 1.0 & 1.7 \\
\hline Growth of real primary spending (deflated by GDP deflator, in percent) & 0.5 & 0.2 & 0.3 & 0.2 & 0.2 & 0.0 & 0.0 & -0.1 & 0.0 & 0.0 & 0.0 & 0.0 & 0.0 & 0.0 & 0.0 \\
\hline Grant element of new external borrowing (in percent) & & $\ldots$ & 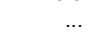 & & & 5.7 & 25.6 & 26.2 & 27.7 & 27.3 & 0.4 & 18.8 & 10.2 & 4.8 & ... \\
\hline
\end{tabular}

$1 /$ [Indicate coverage of public sector, e.g. general government or nonfinancial public sector. Also whether net or gross debt is used]

2/ Gross financing need is defined as the primary deficit plus debt service plus the stock of short-term debt at the end of the last period.

3/ Revenues excluding grants.

the sum of interest and amortization of medium and long-term debt.

$5 /$ Historical averages and standard deviations are generally derived over the past 10 years, subject to data availability. 
Table 2b.Georgia: Sensitivity Analysis for Key Indicators of Public Debt 2008-2028

\begin{tabular}{|c|c|c|c|c|c|c|c|c|}
\hline & \multicolumn{8}{|c|}{ Projections } \\
\hline & 2008 & 2009 & 2010 & 2011 & 2012 & 2013 & 2018 & 2028 \\
\hline \multicolumn{9}{|l|}{ PV of Debt-to-GDP Ratio } \\
\hline Baseline & 21 & 23 & 21 & 19 & 16 & 13 & 10 & 8 \\
\hline \multicolumn{9}{|l|}{ A. Alternative scenarios } \\
\hline A1. Real GDP growth and primary balance are at historical averages & 21 & 19 & 17 & 16 & 15 & 16 & 24 & 42 \\
\hline A2. Primary balance is unchanged from 2008 & 21 & 20 & 17 & 16 & 16 & 16 & 27 & 57 \\
\hline A3. Permanently lower GDP growth $1 /$ & 21 & 23 & 22 & 20 & 18 & 16 & 20 & 46 \\
\hline \multicolumn{9}{|l|}{ B. Bound tests } \\
\hline B1. Real GDP growth is at historical average minus one standard deviations in $2009-2010$ & 21 & 24 & 23 & 21 & 19 & 18 & 18 & 23 \\
\hline B2. Primary balance is at historical average minus one standard deviations in $2009-2010$ & 21 & 20 & 18 & 15 & 13 & 10 & 7 & 5 \\
\hline B3. Combination of B1-B2 using one half standard deviation shocks & 21 & 18 & 14 & 12 & 10 & 8 & 6 & 5 \\
\hline B4. One-time 30 percent real depreciation in 2009 & 21 & 30 & 27 & 25 & 22 & 19 & 16 & 16 \\
\hline B5. 10 percent of GDP increase in other debt-creating flows in 2009 & 21 & 33 & 30 & 27 & 24 & 21 & 17 & 13 \\
\hline
\end{tabular}

PV of Debt-to-Revenue Ratio 2/

Baseline

$\begin{array}{llllllll}75 & 89 & 82 & 73 & 63 & 53 & 43 & 31\end{array}$

A. Alternative scenarios

A1. Real GDP growth and primary balance are at historical averages

A2. Primary balance is unchanged from 2008

A3. Permanently lower GDP growth 1/

$\begin{array}{llllllll}75 & 73 & 65 & 62 & 59 & 63 & 102 & 177 \\ 75 & 75 & 67 & 65 & 62 & 66 & 116 & 238\end{array}$

B. Bound tests

B1. Real GDP growth is at historical average minus one standard deviations in 2009-2010

B2. Primary balance is at historical average minus one standard deviations in 2009-2010

B3. Combination of B1-B2 using one half standard deviation shocks

B4. One-time 30 percent real depreciation in 2009

B5. 10 percent of GDP increase in other debt-creating flows in 2009

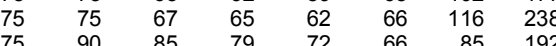

$\begin{array}{rrrrrrrr}75 & 91 & 90 & 68 & 78 & 71 & 76 & 97 \\ 75 & 76 & 69 & 61 & 52 & 42 & 31 & 21 \\ 75 & 69 & 55 & 48 & 40 & 31 & 24 & 22 \\ 75 & 117 & 108 & 80 & 87 & 76 & 67 & 65 \\ 75 & 126 & 118 & 107 & 96 & 84 & 70 & 56\end{array}$

Debt Service-to-Revenue Ratio 2/

Baseline

A. Alternative scenarios

A1. Real GDP growth and primary balance are at historical averages

A2. Primary balance is unchanged from 2008

A3. Permanently lower GDP growth $1 /$

$\begin{array}{rrrrrrrr}7 & 7 & 6 & 7 & 9 & 19 & 22 & 32 \\ 7 & 7 & 6 & 8 & 9 & 20 & 25 & 44 \\ 7 & 7 & 7 & 8 & 12 & 24 & 17 & 37\end{array}$

\section{B. Bound tests}

B1. Real GDP growth is at historical average minus one standard deviations in 2009-2010

B2. Primary balance is at historical average minus one standard deviations in 2009-2010

B3. Combination of B1-B2 using one half standard deviation shocks

B4. One-time 30 percent real depreciation in 2009

B5. 10 percent of GDP increase in other debt-creating flows in 2009

\begin{tabular}{rrrrrrrr}
7 & 7 & 7 & 9 & 14 & 25 & 15 & 19 \\
7 & 7 & 6 & 8 & 9 & 17 & 7 & 6 \\
7 & 7 & 5 & 5 & 5 & 14 & 6 & 5 \\
7 & 8 & 9 & 11 & 16 & 32 & 16 & 17 \\
7 & 7 & 10 & 12 & 14 & 33 & 11 & 13 \\
\hline
\end{tabular}

Sources: Country authorities; and Fund staff estimates and projections.

$1 /$ Assumes that real GDP growth is at baseline minus one standard deviation divided by the length of the projection period.

2/ Revenues are defined inclusive of grants. 


\section{ATtACHMEnT V. GeORgIA: ExCEPTIONAL ACCESS FOR REQUeST OF STAND-By ARRANGEMENT}

\section{A. Introduction}

1. The amount of Fund resources requested by Georgia under the proposed SBA constitutes exceptional access. The total access under the SBA would equal SDR 477.1 million (317 percent of quota), of which SDR 161.7 million would become available upon the Board's approval of the program. ${ }^{1}$ Both the cumulative and annual access under the program would exceed the normal access limits, requiring an evaluation of the case for exceptional access based on consideration of the four substantive criteria under the exceptional access framework. ${ }^{2}$

2. This appendix evaluates the case for exceptional access under the proposed SBA. The evaluation is based on the four substantive exceptional access criteria in capital account crises, as required under the Fund's framework for exceptional access.

\section{B. Exceptional Access Criteria in Capital Account Crises}

\section{Criterion 1-The member is experiencing exceptional balance of payments} pressures on the capital account resulting in a need for Fund financing that cannot be met within normal limits. In the wake of the early August armed conflict, investor confidence has weakened, leading to substantive pressures in Georgia's capital account. This has been reflected in a large loss of international reserves, a fall in bank deposits, and increased Eurobond spreads. Staff estimates that private sector capital inflows could fall to some $\$ 300$ million in the second half of $2008, \$ 1.2$ billion below the record level attained in the first six months, and that gross reserves in the absence of a Fund program would fall to $\$ 920$ million ( $1 \frac{1}{2}$ months of imports). In this context, private inflows would not be adequate to meet the total external financing requirement of $\$ 3.2$ billion and $\$ 2.3$ billion in 2008 and 2009 , respectively, leading to a cumulative balance of payments gap over 2008-10 of $\$ 1.4$ billion ( $\$ 1.2$ billion in 2008-09). In addition, reconstruction needs are expected to result in a higher current account deficit than expected before the conflict. The large financing need also reflects the need to replenish the weak international reserve position of the NBG in 2008 and 2009.

\footnotetext{
${ }^{1}$ SDR 382.5 million (254 percent of quota) would be made available during the first year of the arrangement.

2 There is a presumption that exceptional access in capital account crises will be provided using resources of the Supplemental Reserve Facility (SRF) where the conditions for the SRF apply. In Georgia's case they do not apply. Given that private sector financing is primarily in the form of FDI, a decline of such inflows would likely be protracted and contribute to continued pressures on the capital account. The maturity of the SRF obligations would therefore be too short relative to the likely duration of Georgia's balance of payments need.
} 
4. Criterion 2-A rigorous and systematic analysis indicates that Georgia's debt is low and that there is a high probability that it will remain sustainable. Staff's DSA (Attachment IV) shows that Georgia's public debt ratio will rise over 2008-09 on account of the $\$ 500$ million Eurobond issued earlier this year, purchases under the proposed SBA, and the post-conflict reconstruction-related borrowing on concessional terms. Accordingly, the external public debt would reach 26 percent of GDP by end-2009 compared to 171/2 percent at end-2007. Nevertheless, over the medium term, debt ratios are projected to remain on a firm downward path supported by the government's prudent fiscal policies as demonstrated prior to the conflict. Under a baseline scenario, the external public debt-to-GDP ratio would decline to 15 percent by 2013. Public debt service ratios will remain manageable, but key medium-term risks include large repayments of the 2008 Eurobond and repurchase obligations under the proposed SBA in 2012-13. Another potential vulnerability stems from the rapidly increasing private external debt—mainly by Georgian banks.

\section{Criterion 3 - The member has good prospects of regaining access to private} capital markets within the time Fund resources would be outstanding, so that the Fund's financing would provide a bridge. Georgia successfully tapped the markets for the first time by floating a $\$ 500$ million Eurobond earlier this year. Access and terms have been substantially eroded by the adverse impact of the conflict, with Georgia's sovereign bond spread over comparable U.S. treasuries remaining at 240 points above the pre-conflict level and its sovereign and banks' external debt ratings being lowered by one notch. In staff's view, Georgia should be able to progressively regain market access through 2009 provided that i) regional tensions subside and investor confidence is restored, and ii) government policies (under the program) preserve macroeconomic and financial stability. In this context, the government's strong track record in implementing reforms and attracting FDI, including through privatization, provides grounds for optimism. The program allows for nonconcessional debt of up to $\$ 500$ million in the event the authorities find an appropriate opportunity to tap the markets during the program period.

\section{Criterion 4-The policy program of the member country provides reasonably} strong prospects of success, including not only the member's adjustment plans but also its institutional and political capacity to deliver that adjustment. Georgia established a strong record of policy implementation under the program supported by the PRGF arrangement - which expired last September. This provides a large measure of confidence in the authorities' commitment and ability to implement the policy framework under the proposed SBA aimed at maintaining a prudent macroeconomic policy course and implementing a structural reform effort to restore investor confidence, strengthen the resilience of the financial sector, and spur growth. However, there are significant risks that may imperil the capacity to deliver the adjustment. These involve continued tensions over the two breakaway regions and the domestic political context. 


\section{Overall Assessment}

7. Staff supports the authorities' request for a 18-month SBA. The proposed access would be at the low- to mid-end of other exceptional access cases (see Table). The authorities established a strong record of accomplishment under their PRGF-supported program and have formulated a strong policy framework that addresses the key vulnerabilities facing Georgian economy as a result of the recent crisis. In providing financial support at this critical juncture, when financing needs are large, the Fund can assist Georgia in the needed buildup of reserves and lay the basis for a lasting exit from future Fund financial assistance. The authorities have indicated that decisions on whether to draw future purchases beyond the first one under the proposed SBA will depend on market conditions. 
Georgia: Proposed Access, 2008-2010

\begin{tabular}{|c|c|c|c|c|c|c|c|c|c|}
\hline & \multirow[b]{2}{*}{$\begin{array}{c}\text { Proposed } \\
\text { Arrangement }\end{array}$} & \multicolumn{4}{|c|}{ High-Access Cases $1 /$} & \multicolumn{4}{|c|}{ Normal Access Cases } \\
\hline & & $\begin{array}{l}\text { Proposed } \\
\text { Arrangement } \\
\text { (Percentile) }\end{array}$ & $\begin{array}{c}\text { 20th } \\
\text { Percentile } \\
\end{array}$ & $\begin{array}{c}\begin{array}{c}\text { 80th } \\
\text { Percentile }\end{array} \\
\text { (Ratio) }\end{array}$ & Average & $\begin{array}{l}\text { Proposed } \\
\text { Arrangement } \\
\text { (Percentile) }\end{array}$ & $\begin{array}{c}\text { 20th } \\
\text { Percentile } \\
\end{array}$ & $\begin{array}{c}\begin{array}{c}\text { 80th } \\
\text { Percentile }\end{array} \\
\text { (Ratio) }\end{array}$ & Average \\
\hline \multicolumn{10}{|l|}{ Access } \\
\hline In millions of SDRs & 477 & 1 & 2,894 & 14,635 & 9,157 & 86 & 36 & 409 & 359 \\
\hline Average annual access (percent of quota) & 212 & 55 & 119 & 358 & 249 & 100 & 20 & 50 & 39 \\
\hline \multicolumn{10}{|l|}{ Total access in percent of: $2 /$} \\
\hline Actual quota & 317 & 27 & 272 & 790 & 611 & 100 & 30 & 75 & 62 \\
\hline Gross domestic product & 5.6 & 55 & 2.8 & 8.3 & 6.5 & 98 & 0.7 & 2.7 & 1.8 \\
\hline Gross international reserves $3 /$ & 82 & 69 & 27 & 121 & 97 & 92 & 5 & 41 & 41 \\
\hline Exports of goods and nonfactor services & 20 & 41 & 11.1 & 46.4 & 35.2 & 96 & 1.9 & 7.0 & 5.5 \\
\hline Imports of goods and nonfactor services & 11 & 16 & 14.4 & 64.8 & 36.9 & 92 & 1.6 & 6.4 & 4.8 \\
\hline \multicolumn{10}{|l|}{ Total debt stock } \\
\hline Of which: Public & 33 & 92 & 6 & 16 & 15 & $\ldots$ & $\ldots$ & $\ldots$ & $\ldots$ \\
\hline External & 24 & 96 & 5 & 15 & 11 & 99 & 2 & 6 & 4 \\
\hline Short term & 302 & 100 & 19 & 51 & 45 & $\ldots$ & $\ldots$ & $\ldots$ & $\ldots$ \\
\hline M2 & 42 & 89 & 5 & 24 & 29 & 95 & 1 & 12 & 102 \\
\hline
\end{tabular}

1/ High access cases include all available data at approval and on augmentation for the 25 requests to the Board since 1994 which involved the use of the exceptional circumstances clause or SRF resources. Exceptional access augmentations are counted as separate observations. For the purpose of measuring access as a ratio of different metrics, access includes augmentations and previously approved and drawn amounts.

2/ The data used to calculate ratios is the actual value for the year prior to approval for public and short-term debt, and the projection at the time of program approval for the year in which the program was approved for all other variables.

3/ For Georgia, excludes the purchases under the SBA. 


\section{INTERNATIONAL MONETARY FUND}

GEORGIA

\section{Request for Stand-By Arrangement}

\section{Informational Annex}

Prepared by the Middle East and Central Asia Department

September 10, 2008

Contents

Page

I. Relations with the Fund ............................................................................ 2

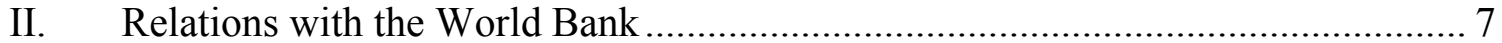

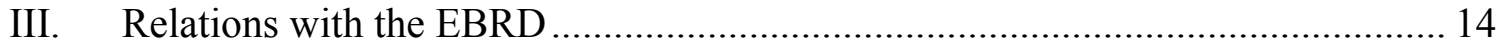

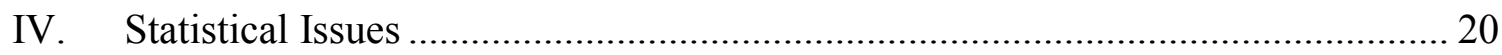

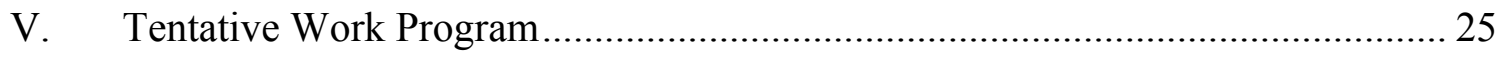




\section{ANNEX I. GEORGIA: RELATIONS WITH THE FUND}

(As of July 31, 2008)

I. Membership Status: Georgia joined the Fund on May 5, 1992.

II. General Resources Account:

Quota

Fund holdings of currency

Reserve position in Fund

III. SDR Department:

Holdings

IV. Outstanding Purchases and Loans:

PRGF Arrangements

V. Latest Financial Arrangements:

$\begin{array}{lcccc}\text { Type } & \begin{array}{c}\text { Approval } \\ \text { Date }\end{array} & \begin{array}{c}\text { Expiration } \\ \text { Date }\end{array} & \begin{array}{c}\text { Amount Approved } \\ \text { (SDR million) }\end{array} & \begin{array}{c}\text { Amount Drawn } \\ \text { SDR Million) }\end{array} \\ \text { PRGF } & 6 / 4 / 04 & 9 / 30 / 07 & 98.00 & 98.00 \\ \text { PRGF } & 1 / 12 / 01 & 1 / 11 / 04 & 108.00 & 49.50 \\ \text { PRGF } & 2 / 28 / 96 & 8 / 13 / 99 & 172.05 & 172.05\end{array}$

VI. Projected Payments to Fund: (SDR million; based on existing use of resources and present holdings of SDRs):

\begin{tabular}{cccccc} 
& \multicolumn{5}{c}{ Forthcoming } \\
\cline { 2 - 6 } & $\mathbf{2 0 0 8}$ & $\mathbf{2 0 0 9}$ & $\mathbf{2 0 1 0}$ & $\mathbf{2 0 1 1}$ & $\mathbf{2 0 1 2}$ \\
Principal & 7.91 & 17.96 & 14.10 & 17.90 & 19.90 \\
Charges/interest & $\underline{0.35}$ & $\underline{0.63}$ & $\underline{0.56}$ & $\underline{0.47}$ & $\underline{0.38}$ \\
$\quad$ Total & 8.26 & 18.59 & 14.66 & 18.37 & 20.28
\end{tabular}

\section{Safeguard Assessments:}

Under the Fund's safeguards assessment policy, the National Bank of Georgia (NBG) is subject to an updated safeguards assessment in the context of the proposed 18-month StandBy Arrangement. A full safeguards assessment with respect to the PRGF arrangement approved on June 4, 2004 was completed on December 10, 2004, and it concluded that safeguards in place at the NBG appear generally adequate in most safeguards areas. Certain vulnerabilities were, however, identified in the internal audit and internal controls areas, and the safeguards assessment recommended measures to address them. The subsequent ongoing monitoring of the NBG indicates that it has met the key requirements of the Fund's safeguards policy, namely: (i) its financial statements comply with a recognized accounting 
and financial reporting framework (i.e., International Financial Reporting Standards); (ii) the financial statements are audited by international firms in compliance with International Standards on Auditing, and receive a "clean" opinion (latest opinion is for the year ended December 31, 2007); and (iii) the audited financial statements are published in the NBG's Annual Report and on its website.

\section{Implementation of Multilateral Debt Relief Initiative (MDRI):}

Not Applicable.

\section{Implementation of HIPC Initiative:}

Not Applicable.

\section{Exchange Arrangements:}

(a) Since April 29, 1993, the Tbilisi Interbank Currency Exchange (TICEX), established by the NBG and a group of commercial banks, has conducted periodic auctions to determine the exchange rate of the domestic currency vis-à-vis the U.S. dollar. These auctions are conducted daily. Foreign exchange bureaus are allowed to buy and sell foreign currency bank notes. Georgia's exchange rate regime is classified as "managed floating." A temporary de facto exchange rate peg to the U.S. dollar was introduced in the wake of the early August armed conflict.

(b) Georgia maintains no exchange restrictions on the making of payments and transfers for current international transactions except for exchange restrictions maintained for security reasons, and notified to the Fund pursuant to Executive Board Decision No. 144-(52/51).

\section{Article IV Consultation:}

The 2006 Article IV consultation was concluded on March 31, 2006.

\section{FSAP Participation:}

Two FSAP missions visited Tbilisi during May 1-15, and July 24-August 7, 2001. An FSAP update mission visited Tbilisi during February 15-28, 2006.

\section{Technical Assistance:}

See Table 1 of this Annex.

\section{Resident Representative:}

The fifth Resident Representative, Mr. Christiansen, took up his post on August 1, 2004 and ended it on August 31, 2008. 


\section{National Bank of Georgia Resident Advisors:}

Ms. Vance, MAE peripatetic banking supervision advisor to the NBG, commenced a series of visits to Tbilisi in September 1997. Mr. Nielsen, an MAE advisor, provided technical assistance to the NBG in May 1998. Mr. Viksnins was an MAE peripatetic advisor to the NBG president starting in October 1999. Mr. Fish was resident advisor on banking supervision from August 10, 1999 to January 31, 2002. Mr. Bernard Thompson provided peripatetic technical assistance in accounting and internal audit in March and August 2000. Mr. Wellwood Mason provided technical assistance on payment system issues on a peripatetic basis in 2002 and 2003. Mr. Howard C. Edmonds serves since September 2004 as a resident advisor on banking supervision issues.

\section{Ministry of Finance Resident Advisors:}

Mr. Sharma was an FAD resident advisor and assisted the authorities in the development of a Treasury beginning in May 1997. Mr. Sainsbury, an FAD advisor, assisted the ministry of finance from June 1998 to November 1999. Mr. Chaturvedi was FAD resident advisor in 2001 and 2002 to assist the authorities in continuing the development of the Treasury and the Treasury Single Account, in revising the legislative framework, expenditure control systems, and budgeting issues. Between 2001 and 2003, Mr. Welling was an FAD peripatetic advisor to assist the State Customs Department in preparing and introducing measures for the custom reform and modernization program. In March 2005, Mr. Zohrab started advising the authorities on treasury-related reforms, and his term ended in November 2006.

Table 1. Georgia: Fund Technical Assistance Missions, 2004-07

\begin{tabular}{|c|c|c|c|}
\hline Subject & Type of Mission & Timing & Counterpart \\
\hline \multicolumn{4}{|c|}{ Fiscal Affairs Department (FAD) } \\
\hline Tax Policy & Review of tax policy & June 8-21, 2004 & Ministry of Finance \\
\hline $\begin{array}{l}\text { Public Expenditure } \\
\text { Management }\end{array}$ & $\begin{array}{l}\text { Assessment of } \\
\text { Treasury system. }\end{array}$ & Nov. 8-23, 2004 & Ministry of Finance \\
\hline $\begin{array}{l}\text { Public Financial } \\
\text { Management }\end{array}$ & $\begin{array}{l}\text { Resident advisor } \\
\text { (Zohrab) }\end{array}$ & Mar. 2005-Nov. 2006 & Ministry of Finance \\
\hline Tax Administration & $\begin{array}{l}\text { Mission-review of } \\
\text { modernization program }\end{array}$ & Nov. 8-21, 2005 & Ministry of Finance \\
\hline Tax Administration & Expert assistance & July 9-14, 2006 & Ministry of Finance \\
\hline Tax Administration & $\begin{array}{l}\text { Expert assistance } \\
\text { (Bosch) }\end{array}$ & Oct. 9-25, 2006 & Ministry of Finance \\
\hline Tax Administration & Follow-up mission & Jan. 17-30, 2007 & Ministry of Finance \\
\hline Tax Administration & Expert assistance & $\begin{array}{l}\text { Jan/Feb and Apr/May } \\
2008\end{array}$ & Ministry of Finance \\
\hline
\end{tabular}


Table 1. Georgia: Fund Technical Assistance Missions, 2004-07

\begin{tabular}{|c|c|c|c|}
\hline Subject & Type of Mission & Timing & Counterpart \\
\hline & (Woodley) & & \\
\hline $\begin{array}{l}\text { Budget Classification } \\
\text { and Accounting Reforms }\end{array}$ & $\begin{array}{l}\text { Expert assistance } \\
\text { (Swarap) }\end{array}$ & June 11-22, 2007 & Ministry of Finance \\
\hline $\begin{array}{l}\text { Budget Classification } \\
\text { and Accounting Reforms }\end{array}$ & $\begin{array}{l}\text { Expert assistance } \\
\text { (Swarap) }\end{array}$ & Oct. 8-19, 2007 & Ministry of Finance \\
\hline \multicolumn{4}{|c|}{ Monetary and Capital Markets Department (MCM) } \\
\hline $\begin{array}{l}\text { Government Securities } \\
\text { Market, Deposit } \\
\text { Insurance, Anti-Money } \\
\text { Laundering }\end{array}$ & Advisory & April 20-30, 2004 & National Bank of Georgia \\
\hline $\begin{array}{l}\text { Monetary Operations, } \\
\text { Banking Sector } \\
\text { Competition }\end{array}$ & Advisory & $\begin{array}{l}\text { Oct. 24-Nov. 5, } \\
2004\end{array}$ & National Bank of Georgia \\
\hline $\begin{array}{l}\text { Liquidity Management; } \\
\text { Trends in Securities and } \\
\text { Insurance Sectors }\end{array}$ & Advisory & April 18-29, 2005 & National Bank of Georgia \\
\hline FSAP Update & Assessment & Feb. 15-28, 2006 & National Bank of Georgia \\
\hline $\begin{array}{l}\text { Monetary } \\
\text { Operations/Monetary } \\
\text { Policy/Foreign Exchange }\end{array}$ & Advisory & $\begin{array}{l}\text { Feb. 16-Mar. 2, } \\
2007\end{array}$ & National Bank of Georgia \\
\hline $\begin{array}{l}\text { Consolidated } \\
\text { Supervision }\end{array}$ & Advisory & Dec. 4-14, 2007 & National Bank of Georgia \\
\hline \multicolumn{4}{|c|}{ Statistics Department (STA) } \\
\hline National Accounts & Follow-up assistance & April 26-May 7, 2004 & $\begin{array}{l}\text { State Department of } \\
\text { Statistics }\end{array}$ \\
\hline National Accounts & Follow-up assistance & April 18-29, 2005 & $\begin{array}{l}\text { State Department of } \\
\text { Statistics }\end{array}$ \\
\hline Price Statistics & Follow-up assistance & May 23-June 3, 2005 & $\begin{array}{l}\text { State Department of } \\
\text { Statistics }\end{array}$ \\
\hline $\begin{array}{l}\text { Balance of Payments } \\
\text { Statistics/International } \\
\text { Investment Position }\end{array}$ & Follow-up assistance & June 15-28, 2005 & $\begin{array}{l}\text { State Department of } \\
\text { Statistics and National } \\
\text { Bank of Georgia }\end{array}$ \\
\hline Price Statistics & Follow-up assistance & June 20-July 13, 2006 & $\begin{array}{l}\text { State Department of } \\
\text { Statistics }\end{array}$ \\
\hline Balance of Payments & Follow-up assistance & Sept. 6-19, 2006 & National Bank of Georgia \\
\hline
\end{tabular}


Table 1. Georgia: Fund Technical Assistance Missions, 2004-07

\begin{tabular}{lccl}
\hline Subject & Type of Mission & Timing & Counterpart \\
\hline $\begin{array}{l}\text { GDDS/Government } \\
\text { Finance Statistics }\end{array}$ & Follow-up assistance & Nov. 8-22, 2006 & $\begin{array}{l}\text { State Department of } \\
\text { Statistics, National Bank } \\
\text { of Georgia, Ministry of } \\
\text { Finance }\end{array}$ \\
Balance of Payments & Follow-up assistance & July 9-20, 2007 & National Bank of Georgia \\
Tax Code & Lollow-up assistance & Jan. 28-Feb. 9, & $\begin{array}{l}\text { Ministry of Finance, Tax } \\
\text { Inspectorate of Georgia }\end{array}$ \\
Tax Code & Follow-up assistance & Jul. 13-24, 2001 & $\begin{array}{l}\text { Ministry of Finance, Tax } \\
\text { Inspectorate of Georgia }\end{array}$ \\
\hline
\end{tabular}




\section{ANNEX II. GEORGIA: RELATIONS WITH THE WORLD BANK \\ Partnership in Georgia's Development Strategy}

1. Georgia joined the World Bank in 1992 and the International Development Association (IDA) in 1993. With borrowing of US\$939.3 million for 43 operations, Georgia is one of the largest IDA borrowers in the CIS. There are currently 19 IDA operations under implementation. The latest World Bank Country Partnership Strategy (CPS) of Georgia for FY06-09 was presented to the World Bank Board of Executive Directors in September 2005. The CPS, built on the Economic Development and Poverty Reduction Program (EDPRP) of the government (its PRSP), was designed to assist Georgia in the implementation of its reform program. A CPS Progress Report to assess the mid-term progress in the implementation of the CPS was presented to the Board in June 2008.

2. The Poverty Reduction Support Operation series of the last three years have been the cornerstone of the Georgia CPS Strategy and have supported further elaboration and implementation of the key elements of the government's poverty reduction strategy as described in the PRSP (EDPRP) Progress Report.

3. A Joint Staff Advisory Note was prepared - which, together with the second PRSP Progress Report - were presented to the Boards of IDA and IMF in September 2006. The IMF presented the staff report of the sixth and final review under the PRGF arrangement to the IMF Board in August 2007. The Third Poverty Reduction Support Operation (PRSO III), was discussed and approved by the Board in June 2007, and the PRSO IV (the last in a series of PRSOs) was approved on May 27, 2008.

4. The IMF has taken the lead in assisting Georgia in improving macroeconomic stability and pursuing fiscal reforms. The World Bank has taken the lead in the policy dialogue on structural issues, focusing on (i) strengthening public expenditure management; (ii) improving performance of the public sector; (iii) reducing corruption; (iv) deepening and diversifying sources of growth; (v) protecting the environment; and (vi) reducing poverty.

5. The PRSO program focuses on four central reform areas: (i) strengthening public sector accountability, efficiency, and transparency; (ii) improving electricity and gas sector services; (iii) improving the environment for private sector development; and (iv) improving social protection, education and health care services.

6. Other support has come in the form of project support and analytical and advisory activities across a broad spectrum of areas including education, health care, social protection, energy, roads, water and sanitation, agriculture, agricultural research and extension, irrigation and drainage, forestry, environment, biodiversity, enterprise development, municipal development, judicial reform, and cultural heritage. A Public Expenditure Review (PER) was 
prepared in 2002, and a Trade Study in 2003. A Country Procurement Assessment Report (CPAR) was prepared in 2002 and a Country Financial Accountability Assessment (CFAA) in 2003. A Country Fiduciary Assessment (CFA) was prepared in 2007. A series of annual programmatic Poverty Assessments are being implemented with a report to be issued in 2008. A Programmatic Public Finance Policy Review (PPFPR) and a Country Economic Memorandum (CEM) are planned for FY09.

7. Georgia became a shareholder and a member of IFC in 1995, and IFC has financed projects in the financial, infrastructure, oil and gas, and manufacturing sectors. IFC's portfolio in Georgia as of January 2008 stands at about $\$ 93$ million with seven clients. In the financial sector, IFC has focused on supporting the development of the housing finance market, providing investment and technical assistance to three leading banks-TBC Bank, the Bank of Georgia, and Bank Republic. To reach small and medium enterprises, IFC helped to establish ProCredit Bank of Georgia, the country's first bank specializing in lending to micro and small enterprises. IFC has also provided a credit line to TBC Leasing to support the rapid growth of their portfolio of SME clients. In FY08, IFC also supported GRDC in their financing of the development of office and retail space. IFC continues to look for opportunities to support these clients, as well as other emerging financial market leaders to deepen the financial sector and increase the range of financial products available.

8. In the real sector, IFC's most recent transaction is a loan to TAV to support their construction of new airport terminals in Tbilisi and Batumi. In oil transit, IFC has provided equity and credit to local and international companies, including investments by British Petroleum and other sponsors in the construction of the Baku-Supsa Early Oil Pipeline and the Baku-Tbilisi-Ceyhan Pipeline. Other investment projects have been in electricity distribution (AES-Telasi), mineral water (GGMW), and glass bottle production (Ksani Glass Factory). In the real sector, IFC continues to look for opportunities to support the growth of the private sector, particularly in export-oriented companies or those that support overall private sector development. Sectors of interest include agribusiness, infrastructure, manufacturing, and the development of natural resources.

9. IFC has also provided donor-supported technical assistance to strengthen its client banks and introduce new financial products (including leasing and housing finance). IFC is currently providing technical assistance in Georgia to improve the business climate and corporate governance practices. The World Bank-IFC Doing Business report has ranked Georgia as a top reformer in its Doing Business 2008 report, and the government is actively engaged with IFC to make further progress on reforms for the business enabling environment.

10. The division of responsibilities between the two institutions is described in the next section. In a number of areas-for example, the social sectors, rural development, environment, and infrastructure- the World Bank takes the lead in the dialogue. The World 
Bank is also leading the dialogue on private sector development and energy. In other areasthe financial sector, public expenditure management, and civil service reform-both institutions are working together. Finally, in areas like monetary policy and domestic customs revenue, the IMF takes the lead.

\section{IMF-World Bank Collaboration in Specific Areas}

\section{Areas in which the World Bank leads and there is no direct IMF involvement}

11. In the social sectors, IDA updates Georgia's Poverty Assessment based on quarterly household survey data. IDA's focus has been to improve execution of budgetary expenditures for health, education and poverty benefits and to raise the efficiency in the use of scarce public resources. Through the Social Investment Fund credits, IDA is focusing in particular on areas with high poverty levels to provide basic infrastructure to the poorest communities. Through the PRSO program, IDA is strengthening the dialogue with the government on social protection reform (safety nets, pensions, poverty benefits, labor market institutions and policies). Under the PRSO program, a poverty benefit targeted for the extreme poor is being implemented.

12. In education, the Adaptable Program Credit of Education System Realignment \& Strengthening Program (APL \#1 and APL \#2) addresses a broad spectrum of educational reform issues aimed at improving learning outcomes of primary and secondary students through curriculum reform, development of a national assessment and examination system, training of teachers, provision of learning materials, and development of capacity to make better use of physical, financial, and human resources. It also tackles key financing issues through the introduction of a per-capita based formula for financing basic education. The second phase of the program provides continued assistance to the implementation of the institutional and policy framework adopted under phase one of the program and includes support to schools in emergency conditions. The PRSO program is supporting the government's efforts in institutionalizing systemic changes initiated with its education reform strategy.

13. In health, IDA credits support the government in improving provision of primary health care services by providing training, equipment and supporting the health information system, as well as capacity building in management. IDA is supporting the provision of health insurance coverage for the poor and has conducted the initial impact evaluation of this program. IDA is engaged in policy dialogue with the government on health sector reform through the PROS program as well as Health Technical Assistance by providing policy advice on regulatory framework for health insurance market, provider payment issues and benefit package. 
14. In infrastructure, support is being provided through the Secondary and Local Roads Project, the First East-West Highway Improvement Project, and the Second East-West Highway Improvement Project to finance improvement of country's main, secondary, and local road infrastructure, as well as through the Municipal Development and Decentralization Project II and the Social Investment Fund Project to finance critical infrastructure needs at the municipal and community level. Under the latter primarily school and health facility heating and repair, small hydropower schemes rehabilitation, drinking water and sanitation rehabilitation, street lightning improvements, as well as local transportation infrastructure rehabilitation has been targeted. The ongoing Infrastructure Pre-Investment Facility project is to facilitate infrastructure investments of strategic importance and/or special complexity by providing technical assistance to assess the feasibility and effectiveness of investments, focusing on energy and transport sectors. Specifically, it targets preparation of First and Second East-West Highway Improvement projects, preparation of Khudoni Hydro Power Plant project (if feasible).

15. In rural development, IDA credits have supported development of private sector farming and agro-processing improvements, agricultural credit, irrigation and drainage, and agricultural research. IDA credits have also been supporting creation of local institutions, such as rural credit unions and water users associations. A recently approved Rural Development Project is to develop the productivity and profitability of the private agriculture sector with the aim to increase incomes and employment and reduce poverty in rural areas.

16. A recently closed Judicial Reform project provided funds for development of new court administration and case management procedures, rehabilitation and construction of courthouses, a computerized network system, assistance for judicial training, and an extensive public information and education outreach effort to inform citizens of their rights and communicate the government's reform efforts.

\section{Areas in which the World Bank leads and its analysis serves as input into the IMF work}

17. The World Bank leads the dialogue on structural reforms through the PRSO program. Institution building and technical assistance have been supported through the Structural Reform Support Project. The World Bank also leads in the areas of:

a) Private sector development. The PRSO program and IFC's advisory work focus on improving investment climate and reducing constraints to private sector development in Georgia. IDA has also been supporting private sector participation in other areas, such as energy, urban services and agriculture. The IMF has worked with the authorities to initiate audits of the accounts of three major state-owned enterprises.

b) Energy. The energy system was in poor condition, with unreliable supply and unsustainable debts. However, under the PRSO program, the Georgian authorities have made 
progress and payment collections and service levels have improved substantially in the power sector. The government of Georgia $(\mathrm{GoG})$ has been working with IDA and other donors, including the IMF, to implement a series of short-term action plans and longer term steps to improve the overall functioning of the sector. At the beginning of the last PRGF program, the IMF focused on reducing quasi-fiscal losses in the sector. The World Bank through the PRSO program focused on improved bill collections, the handling of sector legacy debt, some sector restructuring, and the pursuit of tariff policies at cost-recovery levels was facilitated by a World Bank-assisted review of the tariff policy methodology. The Georgian authorities have prepared and implemented Energy Sector Strategic Action Plans and updates thereof under the PRSO program since 2005. In an ongoing operation, the World Bank finances a feasibility study for a major, new hydropower plant that could add about 20 percent to the country's hydropower capacity.

c) Public sector management. The PRSO program supports through its first pillar, inter alia, improving public expenditure policies and management; implementing procurement reform; strengthening public financial management accountability; implementing intergovernmental fiscal reform; developing a strategy for administrative and civil service reform; and implementing the National Anti-corruption Strategy. The Public Sector Financial Management Reform Support Project (IDA grant pooled together with resources from other donors) is to provide technical assistance and capacity building in support of the first pillar of the PRSO program. The IMF is providing technical assistance in support of tax and customs administration reform.

d) Municipal finance: The Municipal Development and Decentralization Project II has been assisting the government to review the current intergovernmental fiscal relation, and to suggest an equalization transfer system to compensate for horizontal fiscal disparities across local governments.

e) Health sector: The Structural Reform Support Project supported the GoG in the improving of the secondary health care services by reducing the surplus of hospitals and personnel, providing the various types of the technical assistance in health care financing, HR development, service provision, quality of services. A number of medical facilities have been renovated, equipped and staff trained, so they can offer a decent quality of services to the population of Georgia.

\section{Areas of shared responsibility}

18. The World Bank and the IMF have been working jointly in the following main areas:

a) Poverty reduction strategy. Both institutions have worked closely with the government to support the implementation of the PRSP (or EDPRP as it is known in Georgia), through seminars and workshops, direct staff input, and donor coordination. A 
JSAN on the progress with implementation of the government's EDPRP was issued in September 2006.

b) Budget planning and execution. The PRSO program is supporting reforms to improve public expenditure policies and management including development of an MTEF, and strengthening public financial accountability. The Public Sector Financial Management Reform Support Project is financing technical assistance and necessary investment to support budget planning and management processes within the ministry of finance (MoF) and line ministries. The IMF focused on treasury reform within the MoF.

c) Financial sector reforms. The joint Financial Sector Assessment Program has supported (i) strengthened banking and nonbanking supervision; (ii) introduction of international accounting standards; (iii) consolidation of banks through higher capital requirement ratios; (iv) anti-money laundering legislation; (v) strengthening the regulatory environment and removing impediments for development of viable nonbank financial institutions; and (vi) strengthening the payment system. IFC has worked to strengthen the banking sector through investment and technical assistance, and has supported the development of the financial leasing market through technical assistance. The IMF has focused on banking supervision, anti-money laundering legislation, and improvements in monetary control instruments with extensive technical assistance from its Monetary and Capital Markets Department.

\section{Areas in which the IMF leads and its analysis serves as input into the World Bank program}

a) Fiscal framework and reforms in tax policy and tax and customs administration. The IMF's focus on prudent fiscal policy has served as an important framework for IDA's work on public expenditure management. The IMF's Fiscal Affairs Department has the lead in the areas of tax policy and tax and customs administration reform.

b) Economic statistics. IMF technical assistance has been conducive to improvements in national accounts, price, monetary and government financial statistics. The World Bank's grant on Statistical Capacity Building will build on the recommendations of IMF technical assistance to strengthen the quality of national accounts statistics.

\section{Areas in which the IMF leads and there is no direct World Bank involvement}

a) Monetary framework. The IMF collaborates closely with the NBG in the design and implementation of a monetary program that aims at rebuilding international reserves while keeping inflation low and monetizing the economy. 


\section{World Bank Group Strategy}

On September 15, 2005, the World Bank Executive Board endorsed the new Country Partnership Strategy (CPS) for FY06-09 designed to assist Georgia with deeper institutional reform, as well as more fundamental infrastructure improvements. A CPS Progress Report assessing mid-term progress in the implementation of the CPS was presented to the Board in June 2008. In general, the first two and a half years of the CPS period have been characterized by rapid reform with most of the CPS goals achieved on schedule or earlier than anticipated. The First PRSO, of a series of single tranche annual Poverty Reduction Support Operations was approved in September 2005 (US\$13.5 million is a regular IDA credit and US\$6.5 million is an IDA grant). The Second PRSO for US\$20 million of IDA credit was approved by the World Bank's Board in October 2006. The Third PRSO for US\$20 million of IDA was approved by the World Bank Board in June 2007, and the Fourth PRSO (the last in the series of PRSO) was approved in May 2008. Other recent operations include a US\$19 million First East-West Highway Improvement Project approved in November 2006, a US\$35 million Second East-West Highway Improvement Project approved in November 2007, a US\$15 million Education System Realignment \& Strengthening Program supported by the Japanese government cofinancing grant in the amount of US\$4.9 million, a US\$5 million Infrastructure Pre-Investment Facility, a US\$3 million grant Public Sector Financial Management Reform Support Project, a US\$24 million Reform Support Credit, a US\$20 million Secondary and Local Roads Project, a US\$3.6 million Electricity Market Support Project, a US\$10 million Rural Development Project, US\$20 million PHC Development Project, US\$10 million Avian Influenza Control and Human Pandemic Preparedness and Response Project and a US\$5 million Irrigation and Drainage Community Development Project Additional Funding for flood control. The World Bank continues its discussion with the government on a more comprehensive medium-term reform strategy that would be supported by possible future programmatic Development Policy Credit series and technical assistance operations.

Questions may be referred to Ms. Afsaneh Sedghi (202-473-7518), Mr. A. Cholst (202-458-0324), or Ms. R. Quintanilla (202-473-7673). 


\section{ANNEX III. GEORGIA: RELATIONS WITH THE EBRD}

(As of August 18, 2008)

As of June 30, 2008, European Bank for Reconstruction and Development (EBRD) had signed 83 investments in Georgia with cumulative commitments totaling €519 million. Current portfolio stock equals to $€ 369$ million. The EBRD's first operation, a power rehabilitation project, was signed in December 1994. Since then, the pace and composition of portfolio growth has varied significantly from year to year. Our investments in the private sector since 2004 have increased by 153 percent from $€ 160$ million to $€ 441$ million at the end of June 2008.

1. The Bank is currently focusing its efforts on developing infrastructure, reforming the financial sector, supporting energy sector, introducing further market competition, restructuring the corporate sector and introducing sound corporate governance. Currently, EBRD's portfolio counts 38 percent investments into financial institutions sector; 8 percent into infrastructure, 34 percent into corporate sector, and 20 percent into energy sector.

2. During 2007, the Bank signed 22 transactions in Georgia for $€ 192$ million. This is the highest annual business level to date for the Bank in Georgia. For the first half of 2008, EBRD has already committed $€ 61$ million into 9 projects. Some project examples include $€ 30$ million loan framework facility and $€ 10.2$ million equity investment in Georgian Reconstruction and Development Company (GRDC). Together with Meinl European Land, one of the largest European real estate companies, the Bank established Meinl Caucasus and Central Asia Fund, aimed specifically at raising the quality of retail outlets in the major cities in the region. The Bank also introduced its Energy Efficiency Facility in two large Georgian Banks, Cartu Bank ( $€ 8.5$ million) and TBC Bank ( $€ 7$ million). The Medium-Sized Loan Cofinancing Facility was introduced to an additional partner bank, Bank Republic, with a $€ 12.6$ million credit line. EBRD has also signed a €9.5 million mortgage line to TBC Bank; has extended loans in sum of $€ 15.8$ million to three Georgian banks in support of micro and small enterprise development; and arranged a $€ 9.45$ million syndicated loan to ProCreditBank in support of agricultural lending; as well as $€ 12$ million syndicated loan to TBC Bank in support for expansion of its SME lending. $€ 3$ million loan has been granted to the city of Kobuleti to rehabilitate and extend the water and wastewater networks, to install water meters, to construct a wastewater treatment plant.

3. The ratio of private sector projects in the portfolio now stands at 91 percent. The Bank plans to focus primarily on private sector financing, but may also consider selected public sector projects. The Bank will give preference to nonsovereign operations although, where sovereign guarantees will be required, donor cofunding on a grant basis will be sought. 
4. The EBRD is helping Georgia to benefit from its privileged location, transforming it into a regional transportation and natural resources hub. Georgia is part of the "Early Transition Countries" (ETC) initiative. Launched in April 2004, the initiative aims to increase investments in the Bank's seven poorest countries. The initiative builds on international efforts to address poverty in these countries. Through this initiative, the EBRD focuses its efforts on private sector business development and selected public sector interventions. It aims to stimulate market activity by using a streamlined approach to financing, focusing on smaller projects, mobilizing more investment, and encouraging ongoing economic reform. The Bank will accept higher risk in the projects it finances in the ETCs, while still respecting the principles of sound banking. Since launch of the ETC initiative the Bank's annual business volume in Georgia has been increased five times. 
Net Cumulative Business Volume as of January 2008 (EUR)

\begin{tabular}{|c|c|c|c|c|c|}
\hline Op Name & Sector Team & $\begin{array}{r}\text { Total } \\
\text { Project } \\
\text { Value }\end{array}$ & $\begin{array}{r}\text { EBRD } \\
\text { Finance }\end{array}$ & Debt & Equity \\
\hline AES Telasi & Power and Energy & 138.0 & 20.4 & 20.4 & 0.0 \\
\hline Absolute Bank Term Loan & Bank Lending & 1.3 & 1.3 & 1.0 & 0.3 \\
\hline $\mathrm{BIH}$ & Agribusiness & 4.3 & 4.3 & 4.1 & 0.3 \\
\hline BSR Europe Co-Investment Facility & $\begin{array}{l}\text { Property and } \\
\text { Tourism }\end{array}$ & 20.0 & 7.0 & 0.0 & 7.0 \\
\hline Baku-Tbilisi-Ceyhan (BTC) Pipeline & Natural Resources & $1,763.0$ & 42.5 & 42.5 & 0.0 \\
\hline Bank Republic - MSE Loan & $\begin{array}{l}\text { Small Business } \\
\text { Finance }\end{array}$ & 2.0 & 2.0 & 2.0 & 0.0 \\
\hline Bank Republic Equity & Bank Equity & 5.9 & 5.9 & 0.0 & 5.9 \\
\hline Bank Republic Mortgage Loan & Bank Lending & 5.4 & 5.4 & 5.4 & 0.0 \\
\hline Bank of Georgia - SME Loan & Bank Lending & 2.7 & 0.9 & 0.9 & 0.0 \\
\hline Bank of Georgia Capital Increase & Bank Equity & 0.8 & 0.8 & 0.0 & 0.8 \\
\hline $\begin{array}{l}\text { Bank of Georgia Equity and Convertible } \\
\text { Loan (debt \& equity) }\end{array}$ & Bank Equity & 6.1 & 6.1 & 4.2 & 1.9 \\
\hline Baring Vostok Private Equity Fund & Equity Funds & 3.8 & 1.8 & 0.0 & 1.8 \\
\hline Borjomi & Agribusiness & 19.3 & 9.9 & 6.8 & 3.1 \\
\hline $\begin{array}{l}\text { CBG Georgia (sub project of CBG FW) } \\
\text { (equity) }\end{array}$ & Bank Equity & 3.5 & 0.5 & 0.0 & 0.5 \\
\hline CEEP - Cartu Bank & Bank Lending & 3.4 & 3.4 & 3.4 & 0.0 \\
\hline CEEP - TBC & Bank Lending & 3.4 & 3.4 & 3.4 & 0.0 \\
\hline DIF - Alfapet & General Industry & 0.0 & 0.1 & 0.0 & 0.1 \\
\hline DIF - Delidor & Agribusiness & 1.2 & 1.2 & 0.3 & 0.9 \\
\hline DIF - Georgian Hazelnut Production Ltd. & Agribusiness & 2.6 & 0.5 & 0.5 & 0.0 \\
\hline DIF - Iberia Refreshments & Agribusiness & 6.9 & 2.8 & 0.7 & 2.1 \\
\hline DIF - Imedi L & $\begin{array}{l}\text { Nonbank Financial } \\
\text { Institutions }\end{array}$ & 1.2 & 1.2 & 0.0 & 1.2 \\
\hline DIF - Lomisi & Agribusiness & 2.5 & 2.5 & 0.0 & 2.5 \\
\hline DIF - Mantashev Trade Rows JSC & $\begin{array}{l}\text { Property and } \\
\text { Tourism }\end{array}$ & 0.5 & 0.5 & 0.0 & 0.5 \\
\hline DIF - Teliani Valley & Agribusiness & 1.0 & 1.0 & 0.0 & 1.0 \\
\hline DLF - BTM TEKSTIL & General Industry & 4.6 & 1.7 & 1.7 & 0.0 \\
\hline DLF - Georgian Hazelnut Production Ltd & Agribusiness & 2.5 & 2.5 & 2.5 & 0.0 \\
\hline DLF - Lomisi & Agribusiness & 1.4 & 1.4 & 1.4 & 0.0 \\
\hline $\begin{array}{l}\text { ETC Non-Bank MFI Framework II - } \\
\text { Constanta }\end{array}$ & $\begin{array}{l}\text { Small Business } \\
\text { Finance }\end{array}$ & 2.4 & 2.0 & 2.0 & 0.0 \\
\hline $\begin{array}{l}\text { Enguri Hydro power Plant Rehabilitation } \\
\text { project }\end{array}$ & Power and Energy & 62.0 & 33.1 & 33.1 & 0.0 \\
\hline First NIS Regional Fund & Equity Funds & 0.5 & 0.3 & 0.0 & 0.3 \\
\hline Frontera Resources & Natural Resources & 194.0 & 8.8 & 8.8 & 0.0 \\
\hline $\begin{array}{l}\text { Georgia: Trans-Caucasian Rail Link } \\
\text { Project }\end{array}$ & Transport & 23.7 & 13.6 & 13.6 & 0.0 \\
\hline $\begin{array}{l}\text { Georgian Financial Sector F/W - Basis } \\
\text { Bank (MSME Loan) }\end{array}$ & Bank Lending & 1.0 & 2.0 & 2.0 & 0.0 \\
\hline $\begin{array}{l}\text { Georgian Financial Sector F/W-Bank } \\
\text { Republic MSE Loan }\end{array}$ & Bank Lending & 8.2 & 8.2 & 8.2 & 0.0 \\
\hline Georgian Financial Sector F/W-Cartu & Bank Lending & 2.4 & 2.0 & 2.0 & 0.0 \\
\hline
\end{tabular}


Net Cumulative Business Volume as of January 2008 (EUR)

\begin{tabular}{|c|c|c|c|c|c|}
\hline Op Name & Sector Team & $\begin{array}{r}\text { Total } \\
\text { Project } \\
\text { Value } \\
\end{array}$ & $\begin{array}{r}\text { EBRD } \\
\text { Finance }\end{array}$ & Debt & Equity \\
\hline Bank SME Loan & & & & & \\
\hline $\begin{array}{l}\text { Georgian Financial Sector FW-TBC Bank } \\
\text { Mortgage Line II }\end{array}$ & Bank Lending & 4.1 & 4.1 & 4.1 & 0.0 \\
\hline Georgian Property Debt FW - Tbilisi & Property and & 5.8 & 5.8 & 5.8 & 0.0 \\
\hline Central Train Station & Tourism & & & & \\
\hline $\begin{array}{l}\text { Georgian Property Debt Facility - Green } \\
\text { Building }\end{array}$ & $\begin{array}{l}\text { Property and } \\
\text { Tourism }\end{array}$ & 3.8 & 2.3 & 2.3 & 0.0 \\
\hline Georgian Property Equity Investment & $\begin{array}{l}\text { Property and } \\
\text { Tourism }\end{array}$ & 98.6 & 10.8 & 0.0 & 10.8 \\
\hline Georgian Wines & Agribusiness & 3.4 & 3.4 & 3.4 & 0.0 \\
\hline Georgian Wines \& Spirits Ltd. & Agribusiness & 7.0 & 5.6 & 5.6 & 0.0 \\
\hline $\begin{array}{l}\text { Intellectbank (Sub Project of Georgia } \\
\text { SME) }\end{array}$ & Bank Lending & 1.2 & 1.2 & 1.2 & 0.0 \\
\hline JSC Channel Energy Poti Port & Transport & 23.8 & 7.9 & 7.9 & 0.0 \\
\hline Ksani Glass Packaging Factory & General Industry & 14.8 & 2.2 & 2.2 & 0.0 \\
\hline Kutaisi Water Project & Municipal \& Env Inf & 11.9 & 3.0 & 3.0 & 0.0 \\
\hline $\begin{array}{l}\text { Lukoil Overseas : South Caucasus Gas } \\
\text { Pipeline }\end{array}$ & Natural Resources & 31.1 & 20.0 & 20.0 & 0.0 \\
\hline MCFF - Bank Republic - Begi Co. II & Agribusiness & 4.0 & 4.0 & 4.0 & 0.0 \\
\hline MCFF - Bank Republic - Begi Company & Agribusiness & 0.6 & 0.6 & 0.6 & 0.0 \\
\hline $\begin{array}{l}\text { MCFF - Bank of Georgia Full Recourse } \\
\text { Portion }\end{array}$ & Bank Lending & 3.4 & 3.4 & 3.4 & 0.0 \\
\hline $\begin{array}{l}\text { MCFF - BoG Iberia Refreshments Sub- } \\
\text { Loan (NRP) }\end{array}$ & Agribusiness & 2.2 & 2.2 & 2.2 & 0.0 \\
\hline MCFF - TBC - Tsiskvilkombinati II & Agribusiness & 3.4 & 3.4 & 3.4 & 0.0 \\
\hline $\begin{array}{l}\text { MCFF - TBC Bank - Nola Ltd Sub-Loan } \\
\text { (NRP) }\end{array}$ & $\begin{array}{l}\text { Property and } \\
\text { Tourism }\end{array}$ & 1.0 & 1.0 & 1.0 & 0.0 \\
\hline $\begin{array}{l}\text { MCFF - TBC Bank EMBAWOOD Sub } \\
\text { Loan }\end{array}$ & General Industry & 0.7 & 0.7 & 0.7 & 0.0 \\
\hline $\begin{array}{l}\text { MCFF - TBC Bank JSC Full Recourse } \\
\text { Portion }\end{array}$ & Bank Lending & 3.4 & 3.4 & 3.4 & 0.0 \\
\hline $\begin{array}{l}\text { MCFF - TBC Bank Lomisi Ltd Sub-Loan } \\
\text { (NRP) }\end{array}$ & Agribusiness & 4.8 & 2.4 & 2.4 & 0.0 \\
\hline $\begin{array}{l}\text { MCFF - TBC Bank Wissol Sub-Loan } \\
\text { (NRP) }\end{array}$ & Natural Resources & 4.1 & 4.1 & 4.1 & 0.0 \\
\hline MCFF - TBC Coca Cola Ltd. sub-loan & Agribusiness & 4.1 & 4.1 & 4.1 & 0.0 \\
\hline MCFF - TBC Tsiskvilkombinati & Agribusiness & 1.7 & 1.7 & 1.7 & 0.0 \\
\hline $\begin{array}{l}\text { MCFF BOG - Renewable Energy } \\
\text { Programme - Okami SHPP NRP }\end{array}$ & Power and Energy & 0.1 & 0.1 & 0.1 & 0.0 \\
\hline $\begin{array}{l}\text { MCFF BOG - Renewable Energy } \\
\text { Programme Lopota SHPP NRP }\end{array}$ & Power and Energy & 0.1 & 0.1 & 0.1 & 0.0 \\
\hline $\begin{array}{l}\text { MCFF BOG - Renewable Energy } \\
\text { Programme Machakhela SHPP NRP }\end{array}$ & Power and Energy & 0.1 & 0.1 & 0.1 & 0.0 \\
\hline MCFF Bank Republic - Mediclub Georgia & $\begin{array}{l}\text { Property and } \\
\text { Tourism }\end{array}$ & 1.7 & 1.7 & 1.7 & 0.0 \\
\hline MCFF TBC Bank - Goodwill & Agribusiness & 5.1 & 5.1 & 5.1 & 0.0 \\
\hline
\end{tabular}


Net Cumulative Business Volume as of January 2008 (EUR)

\begin{tabular}{|c|c|c|c|c|c|}
\hline Op Name & Sector Team & $\begin{array}{r}\text { Total } \\
\text { Project } \\
\text { Value }\end{array}$ & $\begin{array}{r}\text { EBRD } \\
\text { Finance }\end{array}$ & Debt & Equity \\
\hline Meinl Caucasus and Central Asia & $\begin{array}{l}\text { Property and } \\
\text { Tourism }\end{array}$ & 187.5 & 65.6 & 0.0 & 65.6 \\
\hline NIS Restructuring Facility & Equity Funds & 1.1 & 0.3 & 0.0 & 0.3 \\
\hline Poti Water Supply Project & Municipal \& Env Inf & 12.3 & 2.5 & 2.5 & 0.0 \\
\hline Power Rehabilitation Project & Power and Energy & 16.1 & 12.3 & 12.3 & 0.0 \\
\hline ProCredit Bank Georgia & $\begin{array}{l}\text { Small Business } \\
\text { Finance }\end{array}$ & 8.6 & 4.7 & 2.0 & 2.7 \\
\hline ProCredit Bank Georgia & $\begin{array}{l}\text { Small Business } \\
\text { Finance }\end{array}$ & 10.2 & 4.1 & 4.1 & 0.0 \\
\hline $\begin{array}{l}\text { ProCredit Bank Georgia:Add Senior Loan } \\
\text { USD } 3 \text { million (FIISF) }\end{array}$ & $\begin{array}{l}\text { Small Business } \\
\text { Finance }\end{array}$ & 2.0 & 0.0 & 0.0 & 0.0 \\
\hline ProCredit Georgia - Syndicated Loan & $\begin{array}{l}\text { Small Business } \\
\text { Finance }\end{array}$ & 10.2 & 5.4 & 5.4 & 0.0 \\
\hline $\begin{array}{l}\text { Regional TFP: Bank of Georgia } \\
\text { (Guarantee \& Pre-export) }\end{array}$ & Bank Lending & 16.6 & 16.6 & 16.6 & 0.0 \\
\hline Regional TFP: Cartu Bank & Bank Lending & 1.4 & 1.4 & 1.4 & 0.0 \\
\hline $\begin{array}{l}\text { Regional TFP: TBC Bank (guarantee \& } \\
\text { pre-export) }\end{array}$ & Bank Lending & 36.2 & 36.2 & 36.2 & 0.0 \\
\hline SOCAR - South Caucasus Gas Pipeline & Natural Resources & 34.6 & 6.1 & 6.1 & 0.0 \\
\hline TBC Bank (Sub Project of Georgia SME) & Bank Lending & 1.8 & 1.8 & 1.8 & 0.0 \\
\hline TBC Bank - SME Credit Line & Bank Lending & 4.1 & 4.1 & 4.1 & 0.0 \\
\hline TBC Bank - Syndicated Loan & Bank Lending & 14.3 & 4.8 & 4.8 & 0.0 \\
\hline TBC Bank Mortgage Loan & Bank Lending & 10.2 & 10.2 & 10.2 & 0.0 \\
\hline TBC Bank SME Credit Line III & Bank Lending & 6.8 & 3.4 & 3.4 & 0.0 \\
\hline TBC Leasing - Equity Investment & $\begin{array}{l}\text { Nonbank Financial } \\
\text { Institutions }\end{array}$ & 0.1 & 0.1 & 0.0 & 0.1 \\
\hline TBC Leasing, Senior Debt & $\begin{array}{l}\text { Nonbank Financial } \\
\text { Institutions }\end{array}$ & 2.0 & 2.0 & 2.0 & 0.0 \\
\hline $\begin{array}{l}\text { TbilComBank (Sub Project of Georgia } \\
\text { SME) }\end{array}$ & Bank Lending & 1.7 & 1.7 & 1.7 & 0.0 \\
\hline $\begin{array}{l}\text { TbilcreditBank (Sub Project of Georgia } \\
\text { SME) }\end{array}$ & Bank Lending & 2.0 & 2.0 & 2.0 & 0.0 \\
\hline Tbilisi Airport Refurbishment & Transport & 8.8 & 7.5 & 7.5 & 0.0 \\
\hline Tbilisi International Airport & Transport & 52.0 & 18.3 & 18.3 & 0.0 \\
\hline Tbilisi Public Transport Project & Municipal \& Env Inf & 4.2 & 3.1 & 3.1 & 0.0 \\
\hline $\begin{array}{l}\text { Tbiluniversalbank Small and Micro- } \\
\text { Lending Convertible Loan }\end{array}$ & Bank Equity & 1.6 & 1.6 & 1.0 & 0.6 \\
\hline $\begin{array}{l}\text { Tbiluniversalbanki (Sub loan of Georgia } \\
\text { SME) }\end{array}$ & Bank Lending & 0.7 & 0.7 & 0.7 & 0.0 \\
\hline VTB Bank Georgia & $\begin{array}{l}\text { Small Business } \\
\text { Finance }\end{array}$ & 6.8 & 6.8 & 6.8 & 0.0 \\
\hline VTB Bank Georgia (debt, equity) & Bank Lending & 5.3 & 5.3 & 3.5 & 1.8 \\
\hline \multirow[t]{2}{*}{ VTB Bank Georgia Capital Increase } & Bank Equity & 7.7 & 1.8 & 0.0 & 1.8 \\
\hline & & $3,014.1$ & 535.9 & 422.1 & 113.8 \\
\hline
\end{tabular}




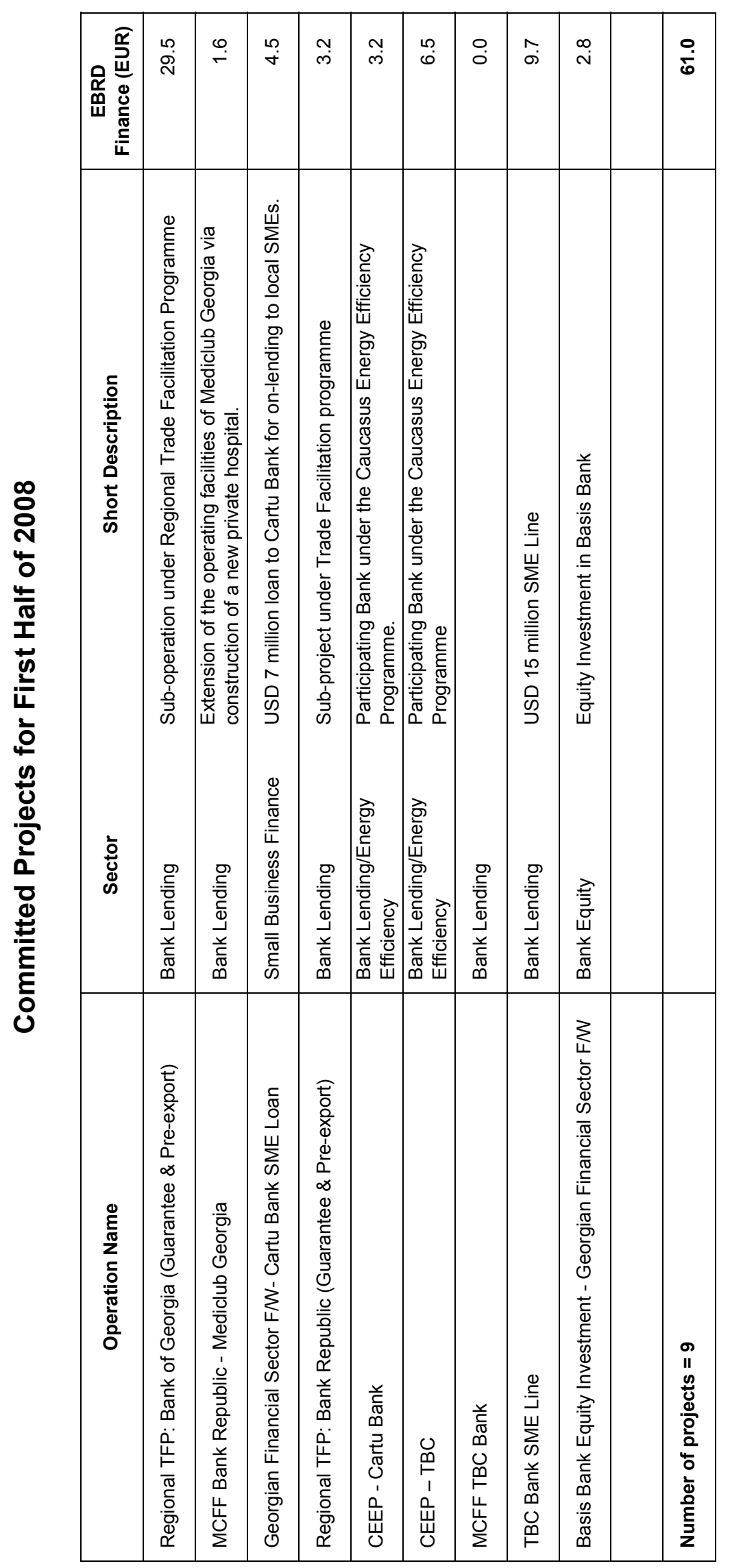




\section{ANNEX IV. GEORGIA: StATistiCAL ISSUES}

1. Data provision has some shortcomings, but is broadly adequate for surveillance and program monitoring. The IMF has provided technical assistance in the compilation of macroeconomic statistics (Annex I, Table 1). Despite improvements in the areas of national accounts, price, monetary, and government finance statistics, the quality of macroeconomic statistics remains poor, reflecting deficiencies in statistical methodologies, coverage, and insufficient resources. Problems are particularly acute in the compilation of national accounts, balance of payments, foreign trade, and fiscal statistics. The transfer of responsibility for the balance of payments from the State Department of Statistics (SDS) to the National Bank of Georgia (NBG) in January 2007 led to improvements.

2. The data module of the Report on the Observance of Standards and Codes (ROSC), prepared in July 2002 was published on the IMF's external website on May 27, 2003. A General Data Dissemination System (GDDS) mission in November helped finalize metadata and on December 15, 2006 Georgia began participation in the GDDS.

\section{Real sector statistics}

3. National accounts statistics follow the concepts and definitions of the System of National Accounts 1993. Annual and quarterly GDP estimates are compiled by both the production and expenditure approaches. Revisions of the national accounts follow an established schedule. Preliminary national accounts estimates are available after 85 days, and final estimates after 13 months. The 2002 data ROSC mission found several weakness regarding data sources, including inadequate coverage of the business register; poor coverage of units in terms of value added for agriculture, retail trade, construction, catering, and services; limited administrative sources to estimate the nonobserved economy; and inadequate data for imports and exports of services (taken from the balance of payments). Follow-up missions in early 2004 and April 2005 found that although the authorities have made good progress in addressing some of these issues, there was scope for improving the constant price estimates and advancing in the development of the system of supply and use tables. On price statistics, Statistics Department (STA) missions in May/June 2006 and August/September 2007 both reported important progress regarding the development of agricultural price indices, although inadequate funding was causing delays in implementation. The authorities' plans include upgrading both CPI and PPI methodology, PPI specification, and dissemination practices.

\section{Monetary and financial statistics}

4. A March 2002 STA mission found that the authorities had implemented many of the recommendations of the December 2000 mission. The July 2002 data ROSC found that most elements in the data quality assessment framework for monetary statistics were fully or largely observed, and recommended improvements in the statistical coverage of nonbank depository corporations and the provision of documentation on metadata. It also 
recommended increased transparency regarding access by governmental agencies to monetary statistics prior to their release to the public.

5. In accordance with the Monetary and Financial Statistics Manual, the NBG has begun compiling monetary data using the framework of the STA's Standardized Report Forms (SRF) and has been providing data regularly. These data have been published in the IFS Supplement since September 2006. Beginning from December 2001, data published in IFS have been revised in accordance with the SRF.

\section{Government finance statistics}

6. Government finance statistics (GFS) on a cash basis are reported to STA for publication in the GFS Yearbook. The GFS mission of November 2006 found that Georgia has embarked on a program of reform to their central and local government budget and accounting systems to fully adopt the GFSM 2001 methodology and the International Public Sector Accounting Standards (IPSASs). The strategy will be implemented in stages. Initially the GFSM 2001 functional and economic classifications are being applied to the current cash data. This will be followed by a staged introduction of accrual recording into transactions data, and an expansion in the range of items recorded in the balance sheet. These reforms are documented in the paper Accounting Reform Strategy, 2007-17. The Georgian authorities' commitment to the accounting reform strategy is set out in Decree 101 issued by the minister of finance on February 10, 2006. This decree approves the general strategy, but implementation of some of the individual steps in the transition plan will require amendments to the law of Georgia on the budget system (Budget System Law).

\section{External sector statistics}

7. A technical assistance mission in September 2006 assisted the authorities to prepare an action plan for the transfer of responsibility for the compilation of balance of payments statistics from the SDS to NBG; advised on the structure of the NBG's new balance of payments division; and developed a framework for the collection of source data. The mission also helped to further develop the framework for compilation of an international investment position statement. The balance of payments compilation function was transferred to NBG in mid-January 2007, although SDS will remain the main provider of data for exports of goods and services and direct investment.

8. The STA resident Statistics Advisor stationed in Baku undertook the first of a series of planned missions to Georgia during April 23-May 4, 2007. Major findings and recommendations of the mission were (i) amendments are needed to the Law on Statistics or to the National Bank Law to assign responsibility and authority for collection, processing and dissemination of international investment position and external debt statistics; (ii) NBG should be represented on the National Statistics Council; (iii) the government and NBG should agree to a data provision/data sharing scheme, such as that proposed by the mission; (iv) a Balance of Payments Expert Group should be established to identify problems in data 
collection, compilation, and dissemination, and also agree on the direction to take for future data improvement; and (v) the international transactions reporting system should be developed and the data collected should be used in the compilation of balance of payments statistics. In addition, recommendations were made for (i) specific improvements to the data collection for private sector liabilities and transactions of the Georgian Pipeline company; and (ii) further investigation of discrepancies between the national data on portfolio investment liabilities and the derived liability data from the Coordinated Portfolio Investment Survey. 


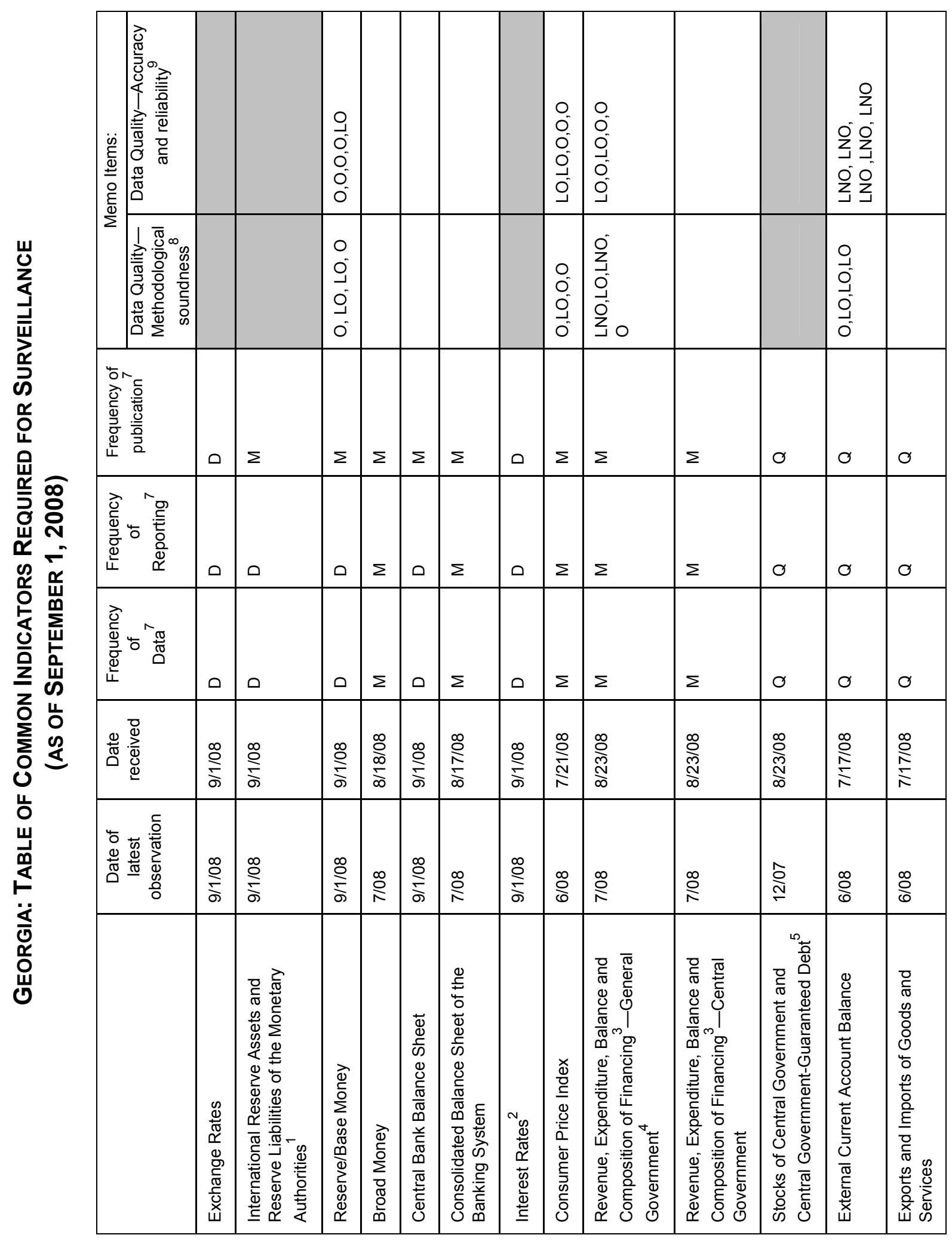




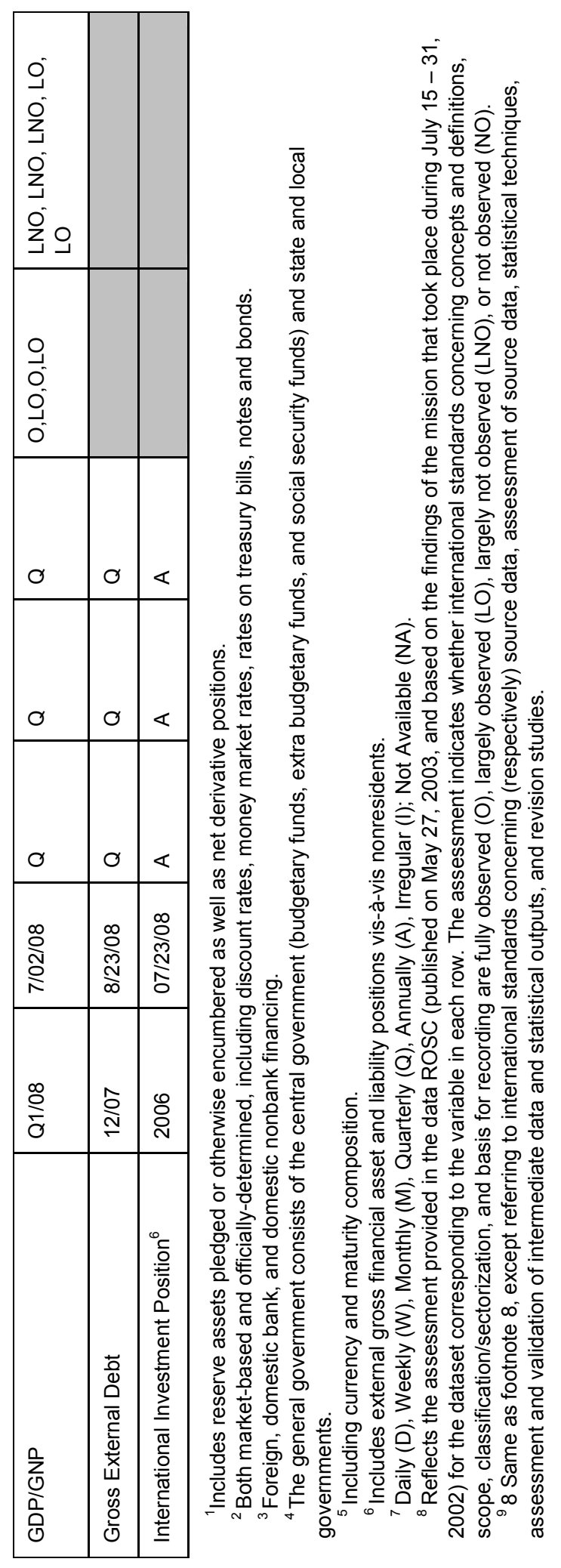




\section{Annex V. Georgia: Tentative Work Program}

Board discussion of an SBA with exceptional access

Mission to conduct the first review under the SBA arrangement

Board discussion for first review

Mission to conduct the second review under the SBA arrangement

Board discussion for second review
September 15, 2008

October 2008

November 2008

January 2009

March 2009 


\section{INTERNATIONAL MONETARY FUND}

\section{Georgia-Assessment of the Risks to the Fund and the Fund's Liquidity Position}

Prepared by the Finance and Strategy, Policy, and Review Departments

In consultation with other Departments

Approved by Andrew Tweedie and Adnan Mazarei

September 12, 2008

1. This note assesses the risks to the Fund arising from the proposed Stand-By Arrangement (SBA) for Georgia and its effects on the Fund's liquidity, in accordance with the policy on exceptional access ${ }^{1}$. The authorities are requesting an 18-month SBA with access of SDR 477.1 million (317.4 percent of quota). A front-loading of SDR 161.7 million (about 108 percent of quota) will be made available upon approval of the arrangement; this would be followed by two quarterly purchases of SDR 63.1 million each, and four quarterly purchases of SDR 47.3 million. The last purchase is scheduled to take place in February 2010 (Table 1).

Table 1. Georgia: Proposed SBA-Access and Phasing

\begin{tabular}{llccc}
\hline \multirow{2}{*}{ Availability Date 1/ } & \multicolumn{3}{c}{ Purchases } \\
\cline { 3 - 5 } & & SDR mn. & \multicolumn{2}{c}{ Percent of quota } \\
\cline { 3 - 5 } & & Annual & Cumulative \\
\hline \multirow{2}{*}{2008} & September (Approval) & 161.70 & 107.58 & 107.58 \\
& November & 63.10 & 41.98 & 149.57 \\
& February & 63.10 & 41.98 & 191.55 \\
& May & 47.30 & 31.47 & 223.02 \\
& August & 47.30 & 31.47 & 254.49 \\
\multirow{2}{*}{2010} & November & 47.30 & 31.47 & 285.96 \\
& February & 47.30 & 31.47 & 317.43 \\
\cline { 2 - 4 } & Total & 477.10 & 317.43 & 317.43 \\
\hline
\end{tabular}

1/ Starting in November 2008, purchases will depend on the completion of a review based on performance criteria for the end of the previous quarter.

\section{Background}

2. Georgia has had an extensive financial relationship with the Fund since becoming a member in May 1992. Georgia made purchases under a systemic

\footnotetext{
${ }^{1}$ See Public Information Notice No. 03/37, 3/21/03
} 
transformation facility (STF) arrangement approved in $1994,{ }^{2}$ under a SBA approved in 1995, and under three Poverty Reduction and Growth Facility (PRGF) arrangements during 1996-2007. Total Fund credit to Georgia rose from zero in November 1994 to a peak of SDR 229 million in 2001, and declined gradually thereafter to SDR 145 million by end-July 2008 (Table 2).

Table 2. Georgia: IMF Financial Arrangements, Purchases and Repurchases, 1994-2011

(in millions of SDRs)

\begin{tabular}{|c|c|c|c|c|c|c|c|c|c|c|c|c|}
\hline \multirow{2}{*}{ Year } & & \multirow{2}{*}{$\begin{array}{l}\text { Type of New } \\
\text { Arrangement }\end{array}$} & \multirow{2}{*}{\multicolumn{2}{|c|}{$\begin{array}{c}\text { Date of } \\
\text { Arrangement }\end{array}$}} & \multirow{2}{*}{$\begin{array}{c}\text { Date of } \\
\text { Expiration or } \\
\text { Cancellation }\end{array}$} & \multirow{2}{*}{$\begin{array}{l}\text { Amount of New } \\
\text { Arrangement }\end{array}$} & \multirow{2}{*}{$\begin{array}{l}\text { Amount } \\
\text { Drawn }\end{array}$} & \multirow{2}{*}{ Purchases } & \multirow{2}{*}{ Repurchases } & \multicolumn{3}{|c|}{ Fund Exposure 1/ } \\
\hline & & & & & & & & & & GRA & PRGF & Total \\
\hline 1994 & & STF & 21 & 15-Dec-1994 & & 55.50 & 55.50 & 27.75 & 0.00 & 27.75 & 0.00 & 27.75 \\
\hline 1995 & & SBA/STF & & 28-Jun-1995 & 28-Feb-1996 & 72.15 & 22.20 & $49.953 /$ & 0.00 & 77.70 & 0.00 & 77.70 \\
\hline 1996 & & PRGF & & 28-Feb-1996 & 13-Aug-1999 & 172.05 & 172.05 & 55.50 & 0.00 & 77.70 & 55.50 & 133.20 \\
\hline 1997 & & & & & & & & 55.50 & 0.00 & 77.70 & 111.00 & 188.70 \\
\hline 1998 & & & & & & & & 27.75 & 0.69 & 77.01 & 138.75 & 215.76 \\
\hline 1999 & & & & & & & & 33.30 & 15.73 & 61.28 & 172.05 & 233.33 \\
\hline 2000 & & & & & & & & 0.00 & 19.66 & 41.63 & 172.05 & 213.68 \\
\hline 2001 & & PRGF & & 12-Jan-2001 & 11-Jan-2004 & 108.00 & 49.50 & 27.00 & 12.03 & 32.37 & 196.28 & 228.65 \\
\hline 2002 & & & & & & & & 22.50 & 23.13 & 23.13 & 204.90 & 228.03 \\
\hline 2003 & & & & & & & & 0.00 & 33.76 & 11.56 & 182.70 & 194.26 \\
\hline 2004 & & PRGF & & 4-Jun-2004 & 30-Sep-2007 & 98.00 & 98.00 & 14.00 & 37.00 & 2.31 & 168.95 & 171.26 \\
\hline 2005 & & & & & & & & 28.00 & 36.72 & 0.00 & 162.54 & 162.54 \\
\hline 2006 & & & & & & & & 28.00 & 33.44 & 0.00 & 157.11 & 157.11 \\
\hline 2007 & & & & & & & & 28.00 & 25.94 & 0.00 & 159.17 & 159.17 \\
\hline 2008 & $4 /$ & & & & & & & 0.00 & 14.21 & 0.00 & 144.97 & 144.97 \\
\hline 2008 & $5 / 6 /$ & $S B A$ & & 15-Sep-2008 & & 477.10 & & 224.80 & 22.11 & 224.80 & 137.06 & 361.86 \\
\hline 2009 & $6 /$ & & & & & & & 205.00 & 17.96 & 429.80 & 119.10 & 548.90 \\
\hline 2010 & $6 /$ & & & & & & & 47.30 & 14.10 & 477.10 & 105.00 & 582.10 \\
\hline 2011 & $6 /$ & & & & & & & 0.00 & 38.11 & 456.89 & 87.10 & 543.99 \\
\hline
\end{tabular}

Source: Finance Department

1/ As of end December, unless otherwise indicated.

2/ The IMF established the Systemic Transformation Facility (STF) as a temporary financing window in April 1993 and allowed it to lapse in April 1995.

3 / Includes a second drawing under the 1994 STF of SDR 27.75 million.

4/ As of end July.

5/ Projected as of end December.

6/ Figures under the proposed program in italics.

3. Georgia's outstanding obligations to the Fund are all to the PRGF Trust. Credit outstanding under the General Resources Account (GRA) reached a peak of SDR 78 million during 1996-98 but has since been fully repaid. Obligations to the PRGF Trust peaked at SDR 205 million in 2002. Performance under all three PRGF arrangements was strong, particularly in the last arrangement (2004-07) where macroeconomic policies and the overall reform effort were better than envisaged under the program.

\footnotetext{
${ }^{2}$ The IMF established the STF as a temporary financing window to provide assistance to member countries facing balance of payments difficulties arising from severe disruptions on their traditional trade and payments arrangements owing to a shift from reliance on trading at non market prices to a multilateral market-based system. The STF was created in April 1993 and allowed to lapse in April 1995.
} 


\section{Georgia's public debt is mostly external, and the Fund is one of its largest}

creditors. As of end-2007, Georgia's public debt was about 22 percent of GDP

(US\$2.2 billion at current exchange rates); 78 percent of which was owed to foreign creditors (Table 3 and Figures 1a-1b). The World Bank accounted for about half of Georgia's public external debt, while the Fund's share was about 14 percent. Georgia's repayment to the Fund represented about 29 percent of public debt service (15 percent of total external debt service) during 2007. As a share of GDP, Georgia's public and external public debt are lower than the corresponding ratios in recent exceptional access cases and the current largest users of Fund resources (Table 4$){ }^{3}$

Table 3. Georgia: Public External Debt, 2004-2007 1/

\begin{tabular}{lrrrr}
\hline & 2004 & 2005 & 2006 & 2007 \\
\hline & \multicolumn{4}{c}{ (In millions of U.S. dollars) } \\
\cline { 2 - 5 } Public and Publicly guaranteed debt & 1,858 & 1,735 & 1,697 & 1,790 \\
Multilateral & 1,102 & 1,053 & 1,140 & 1,263 \\
IMF & 265 & 233 & 236 & 249 \\
World Bank & 678 & 679 & 784 & 883 \\
EBRD & 34 & 30 & 33 & 34 \\
Other & 126 & 111 & 86 & 95 \\
Bilateral & 753 & 679 & 552 & 519 \\
Paris Club & 501 & 485 & 424 & 429 \\
Non-Paris Club & 252 & 194 & 128 & 91 \\
Commercial & 3 & 3 & 6 & 8 \\
Memorandum Item & \multicolumn{4}{c}{} \\
Total external debt & $\ldots$ & 2,093 & 2,328 & 3,136 \\
& (In percent of total public external debt) \\
\cline { 2 - 5 } Public and Publicly guaranteed debt & 100.0 & 100.0 & 100.0 & 100.0 \\
Multilateral & 59.3 & 60.7 & 67.1 & 70.5 \\
IMF & 14.3 & 13.4 & 13.9 & 13.9 \\
World Bank & 36.5 & 39.1 & 46.2 & 49.4 \\
EBRD & 1.8 & 1.7 & 2.0 & 1.9 \\
Other & 6.8 & 6.4 & 5.0 & 5.3 \\
Bilateral & 40.5 & 39.1 & 32.5 & 29.0 \\
Paris Club & 27.0 & 28.0 & 25.0 & 23.9 \\
Non-Paris Club & 13.6 & 11.2 & 7.5 & 5.1 \\
Commercial & 0.1 & 0.2 & 0.3 & 0.4 \\
\hline
\end{tabular}

Source: Georgian authorities and IMF staff estimates

$1 /$ End of year. Public sector is defined as the non-financial public sector and the central bank.

\footnotetext{
${ }^{3}$ The recent exceptional access cases used as comparators in this paper are Argentina, Brazil, Turkey, and Uruguay. The 2008 extended arrangement for Liberia also involved exceptional access. However, this arrangement was different from other exceptional access cases since, in this case, exceptional access was needed to repay the bridge loan used to clear Liberia's arrears to the Fund. For this reason, this paper only groups Liberia with the countries where the Fund had the largest exposure as of end-August 2008 (Turkey, Dominican Republic, Liberia, and Sudan).
} 
Figure 1a. Georgia: Total External Debt by Creditor Group (end-December 2007)

(Nominal Stock: US $\$ 3,136$ million)

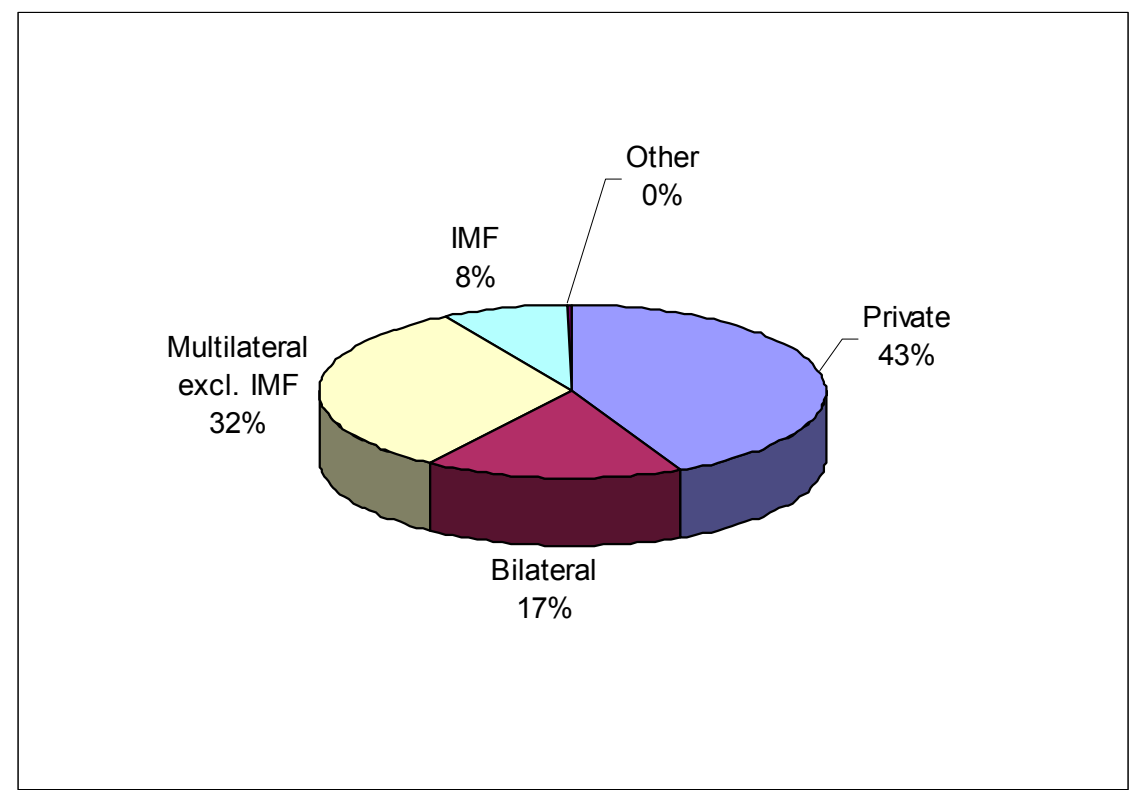

Figure 1b. Georgia: Public External Debt by Creditor Group (end-December 2007)

(Nominal Stock: US\$1,790 million)

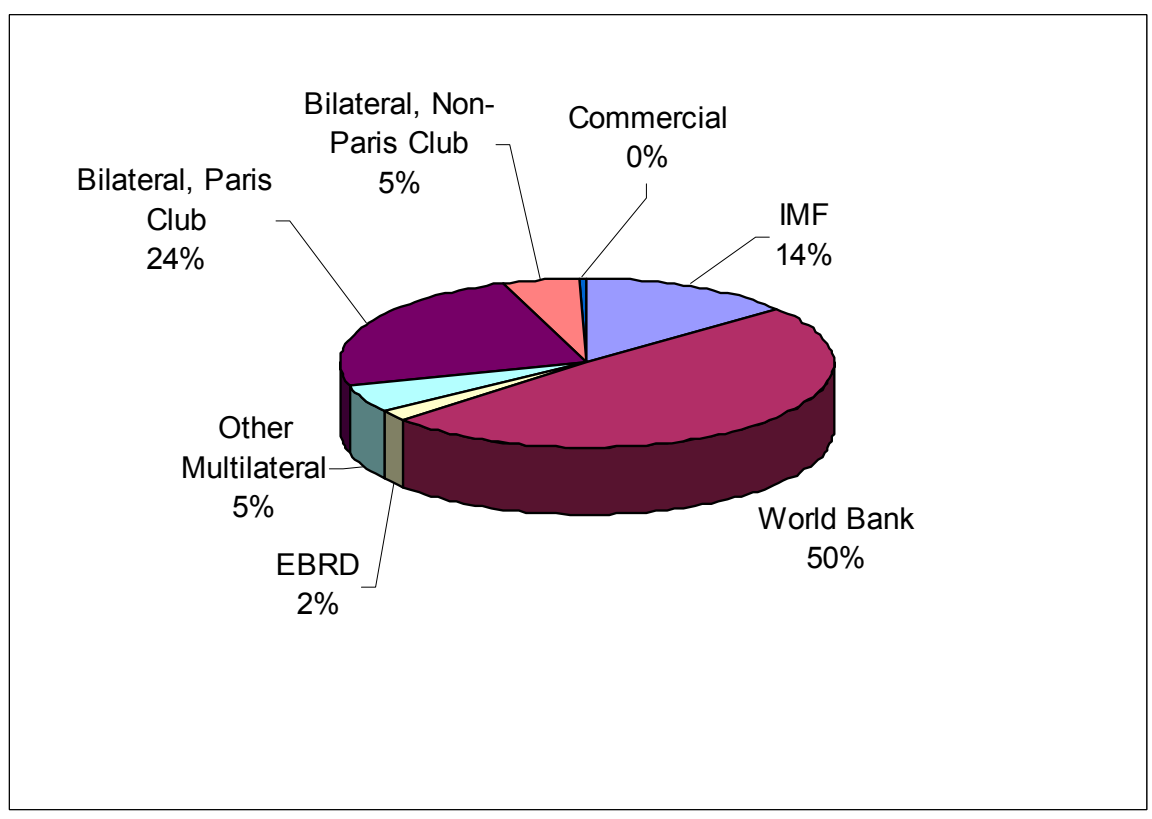

Source: Public sector debt data are from the Ministry of Finance and private sector debt data are based on a recent survey by the National Bank of Georgia. 
Table 4. Public Debt Ratios in Recent Exceptional Access Cases and Current Largest Borrowers from the Fund 1/

(in percent of GDP)

\begin{tabular}{lrrr}
\hline & $\begin{array}{c}\text { Total Public } \\
\text { Debt }\end{array}$ & $\begin{array}{c}\text { Public External } \\
\text { Debt }\end{array}$ & Debt to IMF \\
\hline A. Exceptional Access & & & \\
$\quad$ Argentina (2003) & 149.4 & 87.3 & 11.9 \\
Brazil (2003) & 85.9 & 23.6 & 5.4 \\
Turkey (2005) 2/ & 71.6 & 19.5 & 4.0 \\
$\quad$ Uruguay (2005) & 75.8 & 61.7 & 15.2 \\
B. Current Largest Borrowers 3/ & & & \\
Turkey (2007) 2/ & & & \\
Dominican Republic (2007) & 41.4 & 11.2 & 1.1 \\
Liberia (2007) & 39.3 & 21.4 & 1.5 \\
Sudan (2007) & 774.2 & 709.3 & 3.5 \\
$\quad$ Georgia (2007) & $\ldots$ & 60.0 & $4 /$ \\
& & & \\
\hline
\end{tabular}

Source: Board Documents and IMF staff estimates.

1/ Ratios for the year indicated in parenthesis. For countries in panel A, year in parenthesis corresponds to the year of approval of the last IMF arrangement.

2/ For Turkey, ratios are in percent of GNP.

3/ Countries with the largest Fund exposure as of end August 2008.

4/ Total external debt.

5. Georgia's sovereign risk spread has widened sharply since the start of the armed conflict in early August. While the country has relied mostly on FDI flows to finance its growing current account deficit and government borrowing from nonconcessional sources has been limited, in April of this year Georgia issued its first Eurobond (for US\$500 million) to set a benchmark for the sovereign spread (Figure 2). With the eruption of the conflict the secondary market spread on Georgia's Eurobond increased to a level that is currently some 300 basis points above the EMBI average, and 100 basis points above the spread on Ukraine's debt (which had the same price as Georgia's debt the month prior to the conflict). Spreads on privately issued debt (mainly from commercial banks) have increased even more and are currently some 700 basis points above the sovereign spread.

\section{The New SBA-Risks and Impact on the Fund's Finances}

\section{If the proposed SBA is drawn in full, Georgia's total outstanding use of Fund} resources will reach almost 6 percent of GDP. More than 80 percent of this amount will be from the GRA (Table 5). Georgia's outstanding use of Fund resources in terms of GDP would be lower than the comparable ratios for recent exceptional access cases after their last arrangement was approved (see Table 4, Panel A). However, if the SBA is fully drawn, Georgia's outstanding use of Fund resources relative to GDP will be higher than in three of the four current largest users of Fund resources; of this group, only Liberia will owe more to the Fund relative to GDP than Georgia (Table 5). 
Figure 2. Secondary Market Yields - 2008

(in percent)

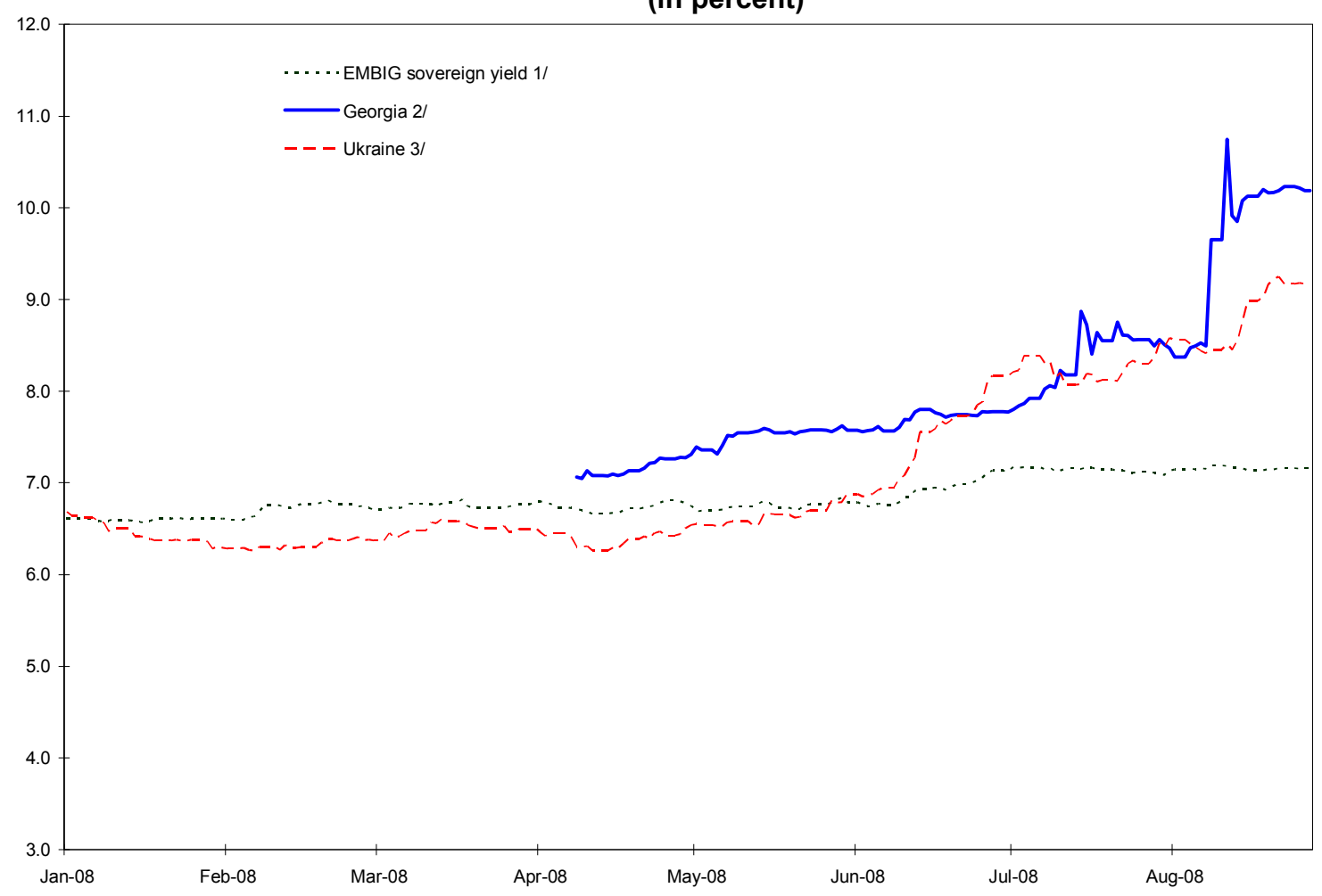

Source: Bloomberg and Finance Department

1/ Composite bond yield for all emerging market countries (does not include Georgia).

2/ Yield on 5-year US dollar denominated bond issued in April 2008 at a coupon rate of 7.5 percent. Up to August 2008 the cost of

Fund credit for Georgia was 0.5 percent, the PRGF interest rate.

3/ Yield on EMBIG US dollar denominated Ukraine bonds.

Table 5. Fund GRA Exposure to Current Largest Borrowers 1/

In SDR Millions $\begin{gathered}\text { In Percent of Total In Percent of Quota In Percent of GDP } \\ \text { GRA credit }\end{gathered}$

\begin{tabular}{|c|c|c|c|c|c|}
\hline Turkey $1 /$ & $6,037.5$ & 78.9 & 506.8 & 1.3 & $3 /$ \\
\hline Dominican Republic 1/ & 350.2 & 4.6 & 160.0 & 1.4 & \\
\hline Liberia 1/ & 342.8 & 4.5 & 265.3 & 65.7 & \\
\hline Sudan 1/ & 220.9 & 2.9 & 130.2 & 2.5 & \\
\hline Georgia 2/ & 477.1 & 6.2 & 317.4 & 4.7 & \\
\hline
\end{tabular}

Sources: Finance Department, Board documents, and IMF staff estimates.

1/ As of end August 2008.

2/ Assuming the proposed SBA is drawn in full. Ratio to GDP based on staff report projections for GDP in 2010

3/ In percent of GNP. 
7. With the proposed SBA, the Fund's share of Georgia's public external debt could increase significantly. If the SBA is fully drawn, Georgia's outstanding use of Fund resources would account for 24 percent of public external debt by February 2010 (outstanding use of the Fund's GRA resources would account for more than 80 percent of this share). At the end of the proposed SBA, the share of Georgia's outstanding use of Fund resources in its public external debt would be higher than in most other recent exceptional access cases (Table 6). In terms of external debt service, Georgia's projected repayments to the Fund would rise from 22 percent of public external debt service in 2008 to over 40 percent in 2011 and close to 70 percent in 2012 (Table 7). This is a significantly higher ratio than applied in other recent exceptional access cases, where repayments to the Fund represented less than $1 / 3$ of total public external debt service.

Table 6. Fund's Share in Public Debt in Recent Exceptional Access Cases 1/ (in percent)

\begin{tabular}{lccc}
\hline & $\begin{array}{c}\text { Public External } \\
\text { Debt }\end{array}$ & $\begin{array}{c}\text { Total Public } \\
\text { Debt }\end{array}$ & $\begin{array}{c}\text { Public External } \\
\text { Debt Service }\end{array}$ \\
\hline Argentina & 15 & 7 & 26 \\
Brazil & 22 & 6 & 28 \\
Turkey & 22 & 9 & 33 \\
Uruguay & 26 & 22 & 34 \\
Georgia 2/ & 24 & 22 & 29 \\
$\quad$ of which: GRA & 20 & 18 & 15 \\
\hline
\end{tabular}

Source: IMF staff estimates.

1/ Argentina, Brazil, Turkey and Uruguay. Figures reported correspond to 2004, the year before three of the four countries (Argentina, Brazil, and Uruguay) made advance repayments to the Fund.

2/ Ratio of outstanding PRGF loans plus the full amount of the proposed SBA to staff projection of public debt in 2010. Debt service figure is the average through 2010 (see Table 7).

8. If all purchases are made as scheduled, Georgia's outstanding use of Fund resources would slightly exceed the cumulative access limit (300 percent of quota) towards the end of the proposed SBA (Table 2, Figure 3). Georgia's outstanding use of the Fund's GRA resources would reach 317 percent of quota in February 2010, and remain at this level through November 2011. ${ }^{4}$ In terms of quota, this peak borrowing would be significantly smaller than in other recent exceptional access cases. Repurchases with respect to the proposed SBA would be subject to surcharges of 100 basis points over the adjusted rate of charge on the credit outstanding exceeding 200 of quota from May 2009 to January 2013, and to surcharges of 200 basis points on the credit outstanding exceeding 300 percent of quota (SDR 25 million) from February 2010 to November 2011.

\footnotetext{
${ }^{4}$ Under the obligations schedule, the first repurchase should take place in December 2011, 31/4 years after the first purchase under the arrangement.
} 


\section{Table 7. Georgia-Impact on GRA Finances (in millions of SDRs, at end of period unless otherwise noted)}

\begin{tabular}{|c|c|c|c|c|c|c|}
\hline & 2008 & 2009 & 2010 & 2011 & 2012 & 2013 \\
\hline \multicolumn{7}{|l|}{ Exposure } \\
\hline Fund GRA credit outstanding to Georgia 1/ & 224.8 & 429.8 & 477.1 & 456.9 & 303.1 & 90.7 \\
\hline Fund GRA credit outstanding to Georgia (percent of total GRA credit outstanding) 2/ & 2.0 & & & & & \\
\hline $\begin{array}{l}\text { Fund GRA credit outstanding to five largest debtors (percent of total GRA credit } \\
\text { outstanding) } 3 /\end{array}$ & 93.1 & & & & & \\
\hline \multicolumn{7}{|l|}{ Liquidity } \\
\hline One-year Forward Commitment Capacity (FCC) 4/ & $127,900.0$ & & & & & \\
\hline Georgia's impact on FCC 5/ & $(477.1)$ & & & & & \\
\hline \multicolumn{7}{|l|}{ Prudential measures } \\
\hline Fund GRA credit outstanding to Georgia (percent of current precautionary balances) 6/ & 3.2 & 6.2 & 6.9 & 6.6 & 4.4 & 1.3 \\
\hline Georgia's annual GRA charges (percent of Fund's residual burden sharing capacity) & 3.3 & 22.3 & 34.6 & 35.6 & 30.4 & 15.8 \\
\hline \multicolumn{7}{|l|}{ Memorandum items } \\
\hline Georgia's GRA credit outstanding (percent of total public external debt) $7 /$ & 12.9 & 18.8 & 20.0 & 19.1 & 13.1 & 4.2 \\
\hline Georgia's GRA credit outstanding (percent of GDP) 7/ & 2.7 & 4.9 & 4.8 & 4.1 & 2.4 & 0.6 \\
\hline Georgia's GRA credit outstanding (percent of gross international reserves) $7 /$ & 28.4 & 38.8 & 38.9 & 35.0 & 22.3 & 6.9 \\
\hline Georgia's GRA debt service to the Fund (percent of exports of goods and services) $7 /$ & 0.1 & 0.5 & 0.7 & 1.2 & 4.7 & 5.5 \\
\hline Georgia's total debt to the Fund (percent of total public external debt) $7 / 8 /$ & 20.8 & 24.1 & 24.4 & 22.7 & 16.0 & 6.5 \\
\hline Georgia's debt service to the Fund (percent of total public external debt service) $7 / 8 /$ & 22.0 & 28.1 & 29.7 & 40.8 & 69.1 & 36.2 \\
\hline Fund's precautionary balances $6 /$ & $6,938.6$ & & & & & \\
\hline Fund's residual burden sharing capacity $9 /$ & 60.2 & & & & & \\
\hline Projected payment of charges to the Fund on GRA credit outstanding & 2.0 & 13.5 & 20.8 & 21.4 & 18.3 & 9.5 \\
\hline Projected debt service payments to the Fund on GRA credit outstanding & 2.0 & 13.5 & 20.8 & 41.7 & 172.1 & 222.0 \\
\hline
\end{tabular}

Source: Finance Department and IMF staff estimates.

1/ The figures do not include SDR 138.86 million (92.39 percent of quota) in PRGF loans outstanding at mid-August 2008 (except for two rows in the memorandum items).

2/ Fund credit to Georgia includes the purchase of SDR 161.70 million upon approval of the proposed SBA.Total GRA credit oustanding is equal to the total as of August 22, 2008, plus the purchase of SDR 161.70 million upon approval of the proposed SBA.

3/ The numerator and the denominator include the purchase of SDR 161.70 million by Georgia upon approval of the proposed SBA.

4/ The Forward Commitment Capacity is a measure of the resources available for new financial commitments in the coming year, equal to usable resources plus repurchases one-year forward minus the prudential balance.

5/ A single country's negative impact on the FCC is defined as the country's sum of Fund credit and undrawn commitments minus repurchases one-year forward.

6/ As of end-April 2008.

7/ Staff projections for total public external debt, GDP, gross international reserves, and exports of goods and services, as used in the staff report that requests the proposed SBA.

8/ Total debt to the Fund comprises balances outstanding on GRA credit and PRGF loans (see footnote 1).

9/ Burden-sharing capacity is calculated based on the floor for remuneration at 85 percent of the SDR interest rate. Residual burden-sharing capacity is equal to the total burden-sharing capacity minus the portion being utilized to offset deferred charges. 
Figure 3. Fund Credit Outstanding in the GRA Around Peak Borrowing 1/ (in percent of quota)

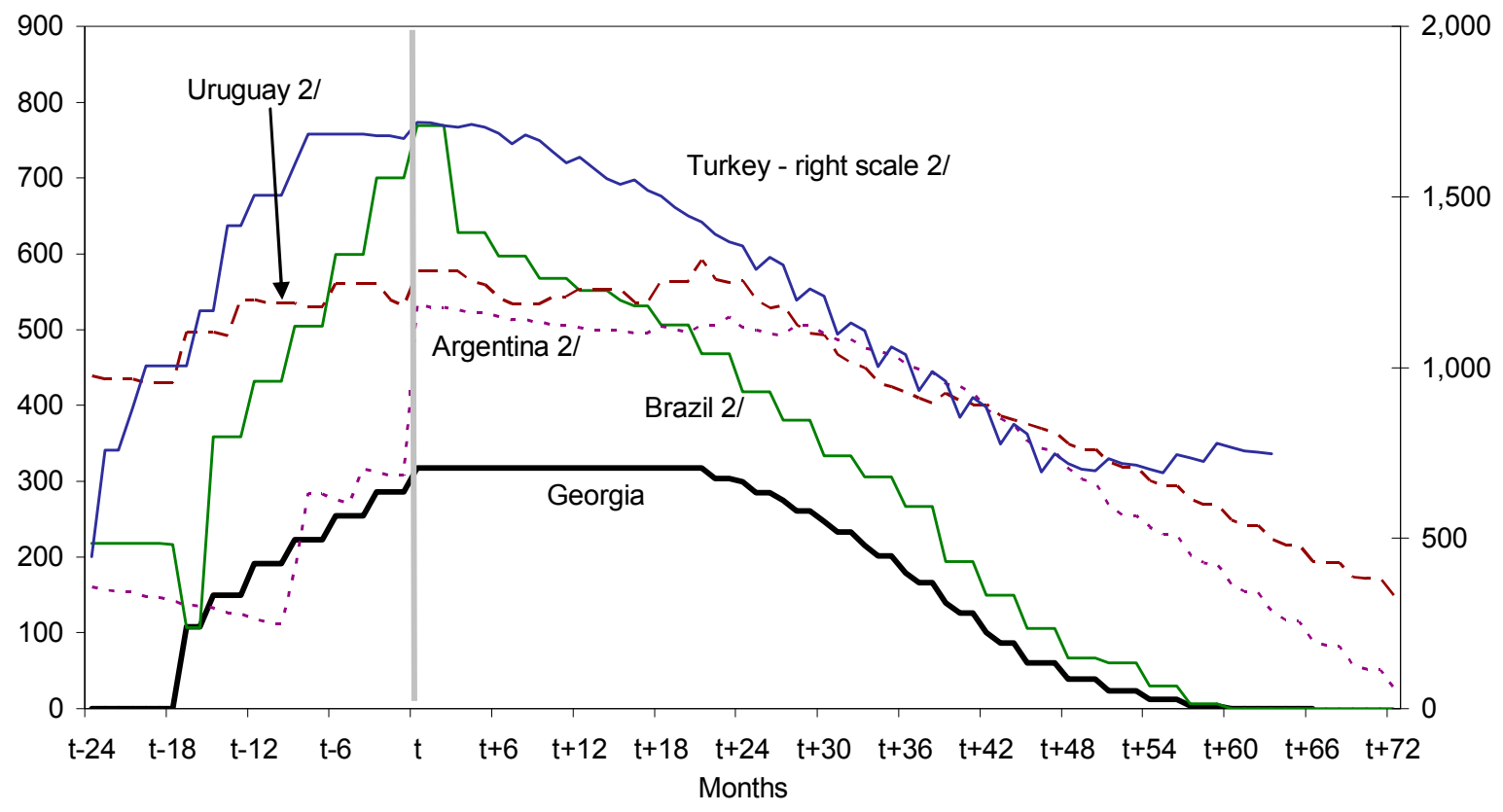

Source: IFS, IMF staff estimates, Finance Department

1/ Peak borrowing is defined as the highest level of credit outstanding for a member, in percent of quota. Month $t$ represents the month of the highest historical credit outstanding (in percent of quota). For Argentina t is September 2001; for Brazil, September 2003; for Turkey, April 2003 and for Uruguay, August 2004. For Georgia, $t$ would be reached in February 2010. For comparability, all projected repurchases are assumed to be on an obligations basis. 2/ Projected repurchases (on an obligation basis) as of May 2005. Schedules do not show large early repurchases made by Argentina, Brazil and Uruguay in 2005-06.

\section{Georgia's repayments to the Fund could increase significantly as a result of the} proposed SBA. Georgia's scheduled repayments to the PRGF will average SDR 18 million (12 percent of quota) per annum for the next several years. If fully drawn, the projected service under the proposed 18-month SBA would average SDR 160 million (107 percent of quota) in 2012-14. ${ }^{5}$ As a result, total payments to the Fund would average close to SDR 180 million in 2012-14, compared with an average of about SDR 30 million in recent years. The repayment of the recently issued US $\$ 500$ million Eurobond, which matures in 2013, would put further strains on Georgia's external debt servicing capacity, unless the government manages to rollover its debt with private creditors.

\footnotetext{
${ }^{5}$ These figures correspond to the repurchase schedule on an obligation basis, in line with the guidelines stipulated in Review of Fund Facilities-Proposed Decisions and Implementation Guidelines (http://www.imf.org/external/np/pdr/roff/2000/eng/fusi).
} 
10. Against this background, the main risks to Georgia's capacity to repay the Fund include:

- A greater-than-anticipated slowdown in private capital flows. Georgia's nearterm macroeconomic stability hinges on avoiding net outflows of private capital and/or large losses of reserves and catalyzing a recovery in the medium term. If the recent conflict turns out to have greater (or longer lasting) adverse effects on FDI flows (the main driver of private capital flows in Georgia) than envisaged in the program, the balance of payments position, and consequently Georgia's capacity to repay the Fund, will be weaker.

- A further deterioration of banks' balance sheets. Banks' large exposure to the real estate sector and their high liability dollarization (both in their deposit base and for wholesale financing) make them particularly vulnerable, especially in view of the strong credit expansion of recent years. A further loss of confidence from depositors or external creditors may exacerbate those vulnerabilities, put pressures on the capital account, reserves and the exchange rate, and give rise to significant liabilities for the government.

- Weak program implementation. Notwithstanding Georgia's track record of sound macroeconomic management, new political realities and/or increased domestic tensions, including pressures to support the banking system or other sectors affected by the conflict, will create challenges for continued fiscal restraint and noninflationary financing of government expenditures.

- An escalation of regional or domestic tensions. Continued or recurrent bouts of violence and political uncertainty would have adverse effects on Georgia's balance of payments above and beyond their impact on investors' confidence, disrupting normal economic activity and foreign trade flows.

- A less benign external environment. Adverse shocks to Georgia's terms of trade or to the global or regional supply of FDI, or a weakening of external demand could lead to a deterioration in Georgia's balance of payments position and its capacity to repay the Fund.

11. The authorities' resolve to implement the policies contemplated in the proposed SBA provides a key safeguard to Fund resources. As noted, the authorities have a strong track record of Fund program implementation. Looking ahead, adhering to their track record of prudent fiscal and monetary policies and economic reform, and developing the capacity to respond quickly to a larger-than-envisaged deterioration of the balance of payments, will be key to limiting the risk of severe balance of payments pressures and/or a financial crisis. 
12. The impact of the proposed SBA on the Fund's liquidity position will be modest. The proposed SBA would reduce the one-year forward commitment capacity (FCC) by SDR 477 million, about 0.4 percent of the FCC as of end-August-SDR 127.9 billion (see Table 7). ${ }^{6}$

\section{The potential GRA exposure to Georgia is also moderate in relation to the} current level of reserves. As a share of the Fund's current level of precautionary balances, outstanding GRA credit to Georgia would be 3 percent in December 2008 and rise to close to 7 percent by December 2010.

14. In an environment of low credit, arrears incurred by Georgia on the charges accruing to its GRA obligations could put significant strain on the Fund's burden sharing mechanism. ${ }^{7}$ Charges on the new GRA obligations will average about SDR 19 million per annum over the next three years. This is equivalent to about 31 percent of the Fund's residual burden-sharing at mid-August 2008. Burden sharing such arrears would imply an increase in the rate of charge of about 12 basis points. ${ }^{8}$

\section{Assessment}

\section{There are significant financial risks associated with the proposed arrangement} for Georgia. Although the size of the credit is relatively small (in SDR terms) and Georgia's outstanding use of Fund resources will account for a small share of the Fund's GRA credit outstanding, there are many factors that may affect adversely, and quickly, Georgia's balance of payments and its capacity to repay the Fund. Those factors include a sudden stop of capital flows (FDI or external credit lines to banks), renewed bouts of deposit withdrawals, renewed hostilities, and heightened social tensions and political uncertainties. Any one of these

\footnotetext{
${ }^{6}$ The FCC is the principal measure of Fund liquidity. The (one-year) FCC indicates the amount of quota-based, nonconcessional resources available for new lending over the next 12 months. See The Fund's Liquidity Position-Review and Outlook (http://www.imf.org/external/np/tre/liquid/2008/0308.htm).

${ }^{7}$ Under the burden-sharing mechanism, the financial consequences for the Fund that stem from the existence of overdue financial obligations are shared between creditors and debtors through a decrease in the rate of remuneration and an increase in the rate of charge, respectively. The mechanism is used to accumulate precautionary balances in the special contingent account (SCA-1) and to compensate the Fund for a loss in income when debtors do not pay charges. The Executive Board has set a floor for remuneration at 85 percent of the SDR interest rate. No corresponding ceiling applies to the rate of charge. The adjustment for the SCA-1 was suspended, effective November 1, 2006, by the Executive Board (Decision No. 13858-(07/1), adopted January 3 , 2007).

${ }^{8}$ Residual burden sharing is equal to total burden-sharing capacity minus the amount currently being utilized to offset unpaid charges. The estimated impact is based on the floor for remuneration at 85 percent of the SDR interest rate. The maximum burden sharing capacity at mid-August 2008 was SDR 72.9 million, of which SDR 60.2 million represented the residual capacity. The capacity of the burden sharing mechanism would decline if outstanding credit declines, but would increase with increases in the SDR interest rate.
} 
factors, in isolation, can lead to large loss of reserves and a currency and/or financial crisis. Georgia's capacity to repay the Fund could be substantially impaired in such a scenario. A quick and peaceful resolution of regional tensions, and the authorities' resolve to adhere to the policies contemplated in the proposed SBA will be key to mitigating those risks.

\section{Georgia's capacity to repay the Fund hinges on maintaining a viable external}

position. This will require policies to significantly reduce the external current account deficit, continue attracting non-debt creating capital flows and re-build reserves. Continued adherence to prudent macroeconomic policies and progress on economic reform, including through timely policy responses to possible new shocks are necessary conditions, and key safeguards, for this outcome. 
Press Release No. 08/208

International Monetary Fund

FOR IMMEDIATE RELEASE

Washington, D.C. 20431 USA

September 15, 2008

\section{IMF Executive Board Approves US\$750 Million Stand-By Arrangement for Georgia}

The Executive Board of the International Monetary Fund (IMF) today approved an 18-month Stand-By Arrangement (SBA), with total access equivalent to SDR 477.1 million (about US\$750 million) to support the Georgian authorities' macroeconomic policies, aiming to rebuild gross international reserves and bolster investor confidence.

The SBA involves exceptional access since it would exceed limits of 100 percent of Georgia's IMF quota annually and 300 percent of the quota (net of scheduled repurchases) cumulatively. An amount equivalent to SDR 161.7 million (US\$250 million) will be made available immediately, with the remaining balance distributed in six installments over the next 18 months.

Following the Executive Board's discussion on Georgia, Mr. Takatoshi Kato, Deputy Managing Director and Acting Chairman, made the following statement:

"In the wake of the early-August armed conflict, Georgia has experienced pressures on the capital account of its balance of payments that have been reflected in a decline in international reserves, a fall in bank deposits, and increased Eurobond spreads. The Fund has approved an 18-month US\$750 million Stand-By Arrangement to make significant resources available to replenish international reserves and bolster investor confidence, with the aim of sustaining private capital inflows that have been critical to Georgia's economic growth in recent years. In addition to Fund resources, Georgia is expected to receive financial assistance from multilateral and bilateral donors and creditors in support of the reconstruction effort.

"The program supported by the Stand-By Arrangement aims to limit the deterioration in the external accounts by containing the fiscal deficit, maintaining a cautious monetary policy stance, and further strengthening the financial sector. The immediate focus will be on avoiding liquidity disruptions and accepting higher fiscal spending on reconstruction. Georgia's track record of adjustment and reform over recent years has strengthened the structure of the economy and its ability to deal with the economic consequences of the shock. 
"On fiscal policy, the plan is to reduce current spending in order to free resources for relief and reconstruction. Concessional loans and grants are expected to be provided by multilateral and bilateral partners to supplement domestic resources in financing further reconstruction needs, and will be accommodated within the program's fiscal targets.

"Monetary policy will focus on providing sufficient liquidity to the banking system while maintaining a stable exchange rate and an adequate level of international reserves. The program supports the authorities' short-term policy of avoiding excessive volatility in the exchange rate but envisages a return to a flexible exchange rate regime.

"The banking system has been resilient to the current pressures, and the supervisory authorities are working with banks on plans to assess vulnerabilities and mitigate risks. The program envisages actions to improve the framework for managing liquidity. It also aims to strengthen the independence and capacity of the Financial Supervision Agency as well as cooperation between the Agency and the central bank," Mr. Kato said. 


\section{Background and Program Summary}

Georgia's near-term growth prospects have been hit by the armed conflict in August 2008, but the economy is well placed to recover from the shock. The impressive record of adjustment and reform over recent years has strengthened the structure of the economy and its ability to deal with the economic consequences of the shock. Before the conflict, economic growth reached double digits, with inflation around 10 percent. The external current account deficit reached 20 percent of GDP in 2007 and was fully financed by private capital inflows, in particular foreign direct investment.

Recent events have led to pressures on Georgia's capital account, reflected in a decline in international reserves, a fall in bank deposits, and increased Eurobond spreads.

The program is designed to make significant resources available in order to replenish international reserves and bolster investor confidence, with the aim of sustaining private capital inflows that have been critical to Georgia's growth performance in recent years.

The authorities' program aims to limit the deterioration in the external accounts by containing the fiscal deficit, maintaining a cautious monetary stance, and further strengthening the financial sector.

On fiscal policy, the plan is to reduce current expenditures in order to free resources for relief and reconstruction. Currently available financing for 2008-09 comprises the proceeds of the $\$ 500$ million Eurobond issued this year, and privatization receipts that will be complemented by donors' support for the reconstruction effort.

Monetary policy will focus on providing sufficient liquidity to the banking system while maintaining a stable exchange rate and an adequate level of international reserves. The program envisages actions to strengthen the framework for providing liquidity to the banking system, build up the capacity of the Financial Supervision Agency (FSA), strengthen its independence, and enhance cooperation between the central bank and the FSA. 


\begin{tabular}{|c|c|c|c|c|}
\hline \multicolumn{5}{|c|}{ Georgia: Selected Macroeconomic Indicators, 2006-09 } \\
\hline & 2006 & 2007 & 2008 & 2009 \\
\hline & Act. & Prel. & Proj. & Proj. \\
\hline & \multicolumn{4}{|c|}{ (Annual percentage change, unless otherwise indicated) } \\
\hline \multicolumn{5}{|l|}{ National accounts } \\
\hline Real GDP growth & 9.4 & 12.4 & 3.5 & 4.0 \\
\hline Population (million) 1/ & 4.3 & 4.4 & 4.4 & 4.4 \\
\hline Consumer price index, period average & 9.2 & 9.2 & 10.0 & 7.6 \\
\hline Consumer price index, end-of-period & 8.8 & 11.0 & 8.0 & 8.0 \\
\hline GDP per capita (US\$) & 1,800 & 2,324 & 2,895 & 3,167 \\
\hline Poverty rate (in percent) & 31.0 & $\ldots$ & $\ldots$ & $\ldots$ \\
\hline \multirow[t]{2}{*}{ Unemployment rate (in percent) } & 13.6 & 13.3 & $\ldots$ & \\
\hline & \multicolumn{4}{|c|}{ (In percent of GDP) } \\
\hline \multicolumn{5}{|l|}{ Investment and saving } \\
\hline Investment & 25.6 & 28.1 & 23.7 & 22.2 \\
\hline Public & 2.5 & 3.4 & 3.6 & 5.6 \\
\hline Private & 23.0 & 24.7 & 20.1 & 16.6 \\
\hline Gross national saving & 9.7 & 8.1 & 2.9 & 3.5 \\
\hline Public & 5.9 & 4.2 & 1.0 & 2.9 \\
\hline Private & 3.7 & 3.8 & 1.9 & 0.6 \\
\hline \multirow[t]{2}{*}{ Saving-investment balance } & -15.9 & -20.0 & -20.8 & -18.7 \\
\hline & \multicolumn{4}{|c|}{ (In percent of GDP) } \\
\hline \multicolumn{5}{|l|}{ Consolidated government operations } \\
\hline Revenue & 26.7 & 29.2 & 27.7 & 26.0 \\
\hline Expenses & 20.8 & 25.0 & 26.6 & 23.1 \\
\hline Operational balance & 5.9 & 4.2 & 1.0 & 2.9 \\
\hline Capital spending and net lending & 9.0 & 9.0 & 7.3 & 6.7 \\
\hline Total balance & -3.0 & -4.7 & -6.3 & -3.8 \\
\hline Statistical discrepancy & 0.0 & 0.2 & 0.3 & 0.0 \\
\hline Total financing (program definition) & 3.0 & 4.5 & 5.9 & 3.8 \\
\hline Domestic & -1.7 & -0.9 & 1.3 & -0.3 \\
\hline External & -0.4 & 0.2 & 1.5 & 3.1 \\
\hline Of which: use of Sovereign Wealth Fund resources & 0.0 & 0.0 & -2.8 & 2.5 \\
\hline Privatization receipts & 5.2 & 5.2 & 3.2 & 0.9 \\
\hline & \multicolumn{4}{|c|}{ (Annual percentage change, unless otherwise indicated) } \\
\hline \multicolumn{5}{|l|}{ Monetary sector } \\
\hline Reserve money & 19.2 & 25.6 & 19.0 & 12.0 \\
\hline Broad money (including foreign exch. deposits) & 39.3 & 49.6 & 14.0 & 18.0 \\
\hline Private credit & 53.4 & 68.9 & 21.2 & 15.2 \\
\hline \multicolumn{5}{|l|}{ External sector } \\
\hline Exports of goods and services (percent of GDP) & 33.1 & 31.7 & 27.6 & 29.2 \\
\hline Annual percentage change & 17.6 & 26.1 & 13.1 & 11.5 \\
\hline Imports of goods and services (percent of GDP) & 56.8 & 57.8 & 53.4 & 52.9 \\
\hline Annual percentage change & 33.0 & 34.0 & 20.0 & 4.1 \\
\hline Current account balance (in millions of US $\$$ ) & $-1,235$ & $-2,047$ & $-2,757$ & $-2,618$ \\
\hline In percent of GDP & -15.9 & -20.0 & -20.8 & -18.7 \\
\hline Gross international reserves (in millions of US $\$$ ) & 881 & 1,361 & 1,270 & 1,755 \\
\hline In months of next year's imports of goods and & 1.8 & 2.3 & 2.1 & 2.6 \\
\hline Foreign direct investment (percent of GDP) & 13.9 & 15.3 & 9.3 & 8.6 \\
\hline
\end{tabular}




\section{Statement by Age Bakker, Executive Director for Georgia September 15, 2008}

Over the last years Georgia's relations with the International Monetary Fund (IMF) have been excellent. The three-year PRGF arrangement, which was completed successfully in September 2007, supported a wide range of economic reforms and thus laid the foundation for Georgia's recent strong macro-economic performance. This strong performance has been very dependent on foreign inflows, mainly in the form of FDI.

As a result of the recent armed conflict, economic activity has been disrupted and investor confidence has been eroded. The Georgian authorities have requested the support from the IMF because they believe that such support can counter the erosion of investor confidence. The authorities are confident that the economy will recover from the conflict as a package of decisive measures, supported by a Stand-By Arrangement with the Fund, will succeed in reassuring the domestic and foreign business community as soon as possible.

The authorities strongly believe that their sound record of growth and stability can be continued in the future as stable macroeconomic conditions will continue to prevail and investors will be reassured that Georgia remains an attractive place for business.

The authorities are grateful for the swift and decisive response of management to their request for assistance and they are particularly grateful for the excellent and dedicated work of staff, who had to work under time pressure in a difficult and uncertain environment.

\section{Georgia's performance}

Since 2004, Georgia has implemented a policy of comprehensive economic reform, based on the firm conviction that economic growth and competitiveness are best fostered through private investment. To this end, barriers to private sector activity were eliminated through a comprehensive program of structural reform, deregulation and privatization. Georgia ranks as one of the top performers in the Doing Business survey, moving up to rank 15 on the ease of doing business in the 2009 survey which was published this week by the World Bank.

Economic growth over the past years has been at double digits. At the same time, inflationary pressures were inevitable, but intensified efforts to reduce inflation to single-digits have been successful, despite the complicated global environment of high energy and food prices.

Georgia's extraordinary growth performance has been driven by private capital inflows. By 2007 , private capital inflows had increased to $\$ 2.2$ billion (22 per cent of GDP) and they continued unabated in the first half of 2008. At the same time the current account deficit has increased substantially (to 26 per cent of GDP in the first half of 2008) and this has made the economy vulnerable to sudden reversals in investor confidence.

Exports have grown exponentially (average annual growth of 26 per cent over 2003-07) and have been significantly diversified. Georgia is actively pursuing free-trade agreements with Turkey and the United States, and it benefits from good trade relations with the European Union. 
Greatly improved revenue performance has allowed Georgia to modernize its state and civil service, enhance the social safety net and invest in infrastructure. This achievement was the result of improved tax administration, simplified procedures, better taxpayer services, and, most important, fewer taxes and lower rates. During the first half of 2008, revenue collection and privatization proceeds exceeded the forecasts. The major part of the proceeds of a Eurobond, which was issued successfully in April 2008, were transferred to newly created sovereign wealth funds.

Recently the institutional set-up for the conduct of monetary policy and supervision has been modernized. Amendments to the central bank law now make price stability the primary objective of the National Bank of Georgia (NBG), requiring the NBG to target single-digit inflation. At the same time a new Financial Supervision Agency (FSA) was created as a fully independent agency with its own supervisory board. The FSA will be responsible for the consolidated supervision of banks, insurance companies and securities firms.

As a result of tight monetary policy both reserve money growth and the growth of bank credit have slowed significantly in the first half of this year. At the same time, the NBG has allowed much greater flexibility in exchange rates and the lari has appreciated by nearly 13 percent vis-à-vis the US dollar in the course of this year, thereby contributing to reducing inflation.

\section{Going forward}

As a result of the armed conflict, the macroeconomic outlook has deteriorated as private inflows are expected to slow down sharply. This sharp downward revision of economic prospects has brought the vulnerability of the external sector to the fore. In the absence of international support, including from the IMF, Georgia's international reserves would decline sharply over the remainder of this year and next, to a level that would cover just a few weeks of imports. This would further increase vulnerabilities and substantially weaken Georgia's external position. Strong and rapid international support will therefore be essential to allow the maintenance of an adequate level of reserves.

The staff projection of a financing gap of about $\$ 1.2$ billion over 2008-09 is expected to be only partially covered by the IMF as there is a strong expectation on the part of the authorities that grants and concessional financing provided by other IFIs and bilateral donors and creditors will be forthcoming. The authorities intend to make a first drawing under the SBA to shore up reserves to close to the targeted level over the program period. This would provide the program with a strong starting position and assist in a rebound of confidence among investors. Such initial drawing would also be helpful as long as there are no concrete indications regarding the size and the timing of donor assistance.

There is a clear understanding that Fund credit would solely be used to bolster central bank reserves and would not be used to finance the fiscal deficit. The authorities are hopeful that, with international assistance from other sources forthcoming, the remainder of the financial support under the program can be regarded as precautionary as inflows resume. 
The authorities are fully committed to a flexible exchange rate policy. It was necessary to defend the lari during the crisis period in order to prevent further uneasiness in the market. Under the program, priority will be given to maintaining the targeted level of international reserves, and the exchange rate will be allowed to adjust to a shortfall in foreign inflows.

The program supported by the Stand-By Arrangement with the IMF is expected to restore investor confidence. Private inflows are anticipated to pick up modestly in 2009 and sustain higher investment, while export growth is expected to increase gradually. As a result, real GDP growth is projected to recover to mid single digits, while inflation (which would remain in single digits) would decline gradually. The current account deficit, while still large, is expected to decrease over time to around 16 per cent of GDP in 2010.

As spelled out in greater detail in the Letter of Intent, the authorities have taken a number of comprehensive measures to ensure that the fiscal deficit will remain within the agreed targets of 6 per cent in 2008 and 33/4 per cent in 2009. These targets will be subject to an upward adjustor in case concessional donor financing exceeds pre-conflict commitments. To increase transparency, the Ministry of Finance will produce annual reports on consolidated public expenditures and public arrears and debt.

The reconstruction costs, provisionally estimated at around $\$ 1$ billion, including the resettlement costs for displaced persons, will require an increase in spending, and therefore some temporary increase in the fiscal deficit is inevitable. Since much of this spending is likely to be financed by donor grants, the maintenance of a sound macroeconomic fiscal framework in the medium term is feasible. The Georgian authorities remain committed to structurally minimize the size of the fiscal footprint on the economy.

Monetary policy will remain strongly committed to maintaining single-digit inflation and reducing it gradually in the medium term. To this end the authorities plan to adopt an inflation-targeting regime in the course of 2009. In the immediate future, monetary policy will be guided by quarterly targets for the net international reserves and net domestic assets of the NBG, as set out in the program.

The loss of confidence has had a serious impact on bank liquidity. This has made it necessary for the NBG to waive the reserve requirements on a temporary basis, and activate an uncollateralized lending facility. In the coming months a liquidity management framework will be developed in order to preserve financial stability and ensure a smooth functioning of the payments system. The NBG will also revise its lender of last resort facility to ensure that this would not encourage excessive risk-taking by financial institutions. Close collaboration with the FSA will be needed.

The financial sector has shown considerable overall stability and resilience during the recent conflict. The NBG and FSA have worked well together to ensure the smooth operation of the payments system, as well as to maintain public confidence in the lari and the banks.

Nevertheless, the authorities are fully aware that substantial risks for financial stability remain. The FSA has started to assess any potential vulnerabilities in the banking sector by conducting on-site inspections. Next, the FSA will make sure that the banks have 
contingency plans readily available to mitigate potential liquidity and capital pressures in the near future.

Cooperation between the FSA and the NBG needs to be further strengthened, including arrangements for information exchange on individual institutions' positions and for sharing possible irregularities in the financial system. The authorities would welcome a streamlined and focused Financial Sector Assessment Program (FSAP) update mission in the second half of 2009 to assess developments in the financial sector and review the new regulatory set-up.

\section{In closing}

The Georgian authorities are grateful for management, staff and the Board to agree on a program under the Stand-By Arrangement under the exceptional access procedures. They fully understand that the support of the IMF builds on the excellent relationship with the IMF over the past years and the good track record built up under previous programs. They are fully committed to bring the program to a successful ending and they are confident that the IMF's support will be helpful in getting the economy back on track. They stand ready to take additional measures if this were to be necessary. Georgia will maintain the usual close policy

dialogue with the Fund. Such dialogue can be assisted by the continued presence of a resident representative, should the IMF decide to maintain the post open. 